\title{
MEMORIAS SEGUNDO ENCUENTRO DE INVESTIGADORES FACULTAD DE CIENCIAS AGROPECUARIAS Y RECURSOS NATURALES UNIVERSIDAD DE LOS LLANOS
}

\author{
PROCEEDINGS FIRST MEETING OF RESEARCHERS FACULTY OF \\ AGRICULTURAL SCIENCES AND NATURAL RESOURCES LLANOS \\ UNIVERSITY
}

agroforesteria@unillanos.edu.co

Septiembre 26 y 27 de 2019

\section{PRESENTACIÓN}

La Universidad de los Llanos y la Facultad de Ciencias Agropecuarias y Recursos Naturales, invitaron a la comunidad académica: Docentes, Egresados y otros profesionales a participar en el segundo Encuentro de Investigadores mediante la presentación de sus trabajos de investigación realizados en los últimos tres años, considerando que esta Facultad ha generado suficiente conocimiento en el área Agropecuaria para la región de la Orinoquia.

Los trabajos fueron presentados en resúmenes para su publicación. Para la exposición de sus resultados se hicieron en forma de ponencia y posters.

Los temas tratados fueron: Ponencias magistrales, Ciencias Animales, Ciencias Agrícolas, Procesos Agroindustriales y Desarrollo Rural.

El evento fue organizado por la Facultad de Ciencias Agropecuarias y Recursos Naturales, Centro de investigaciones y proyección social, Coordinado por el grupo de Investigación en Agroforesteria. 
COMITÉ ORGANIZADOR DEL SEGUNDO ENCUENTRO DE INVESTIGADORES DE LA FACULTAD DE CIENCIAS AGROPECUARIAS Y RECURSOS NATURALES DE UNILLANOS

Coordinadora General del Evento MARIA LIGIA ROA VEGA, Docente Universidad de los Llanos y directora del Grupo de Investigación en Agroforesteria.

CAMILO ANDRÉS DÍAZ ARIAS, MVZ, Joven investigador del Grupo de Investigación en Agroforesteria.

IVAN ESTEBAN MARIÑo GUERRERO, MVZ, Técnico pecuario del Departamento de Producción Animal.

YORMAN DAVEY VELAZQUEZ PIÑEROS, monitor y estudiante del programa de Medicina Veterinaria y Zootecnia 


\section{COMITÉ CIENTIFICO}

Camilo Hernando Plazas Borrero

Profesor de la Universidad de los Llanos

Pregrado/Universitario Universidad de Caldas - Médico Veterinario y Zootecnia

Especialización Universidad de los Llanos, Producción Agrícola Tropical

sostenible

Maestría/Magister Universidad de los Llanos, Producción Tropical Sostenible

\section{Álvaro Ocampo Durán}

Profesor de la Universidad de los Llanos

Pregrado/Universitario Universidad Nacional de Colombia - Sede Palmira

Zootecnia

Maestría/Magister Pontificia Universidad Javeriana - Puj - Sede Bogotá, Magister

En Desarrollo Sostenible de Sistemas Agra

Doctorado University Of London, Animal Science

\section{Pedro Rene Eslava Mocha}

Profesor de la Universidad de los Llanos

Pregrado/Universitario Universidad Nacional de Colombia - Sede Bogotá Médico Veterinario

Maestría/Magister Universidad Nacional de Colombia - Sede Bogotá, Maestría en Sanidad Animal

Candidato a Doctorado

Yohana María Velasco Santamaría

Profesora de la Universidad de los Llanos

Pregrado/Universitario Universidad Nacional de Colombia - Sede Bogotá, Medicina Veterinaria

Maestría/Magister University Of Plymouth, MRes in Applied Fish Biology

Doctorado University of Shouthern Denmark, PhD in Biology - Research area in Ecotoxicology

\section{Edgar Edilberto Fuentes Reyes}

Pregrado/Universitario Universidad de Los Llanos - Unillanos, Medicina Veterinaria Y Zootecnia

Especialización Universidad El Bosque, Docencia universitaria Maestria/Magister Universidad De Sao Paulo, Medicina Veterinária (Reprodução Animal)

Doctorado Universidad De Sao Paulo, Medicina Veterinaria (Cirugia) 


\title{
PONENCIAS MAGISTRALES
}

\section{Avances en el desarrollo de alternativas forrajeras de uso múltiple. Opciones sostenibles para ganaderías en el trópico}

\section{Advances in the development of forage alternatives for multiple use. Sustainable options for livestock in the tropics}

\author{
Camilo Hernando Plazas $\mathrm{B}^{1}$ \\ ${ }^{1}$ MVZ. Esp. Ms. Docente de la Universidad de los Llanos, Grupo de Investigación \\ de Agroforesteria \\ cplazasb@unillanos.edu.co
}

\begin{abstract}
RESUMEN
Los principales problemas para aumentar la productividad en los sistemas de producción de rumiantes son: 1. Limitada cantidad y calidad del forraje en oferta, particularmente en la época seca, lo que se refleja en un deficiente aporte de nutrientes digestibles totales generando, una baja fermentación microbial con poco flujo y absorción de los mismos en el tracto posterior del animal, especialmente la proteína, la cual afecta de forma negativa la conversión alimenticia; 2. Falta potencial genético para producir leche y 3 . Manejo deficiente de los hatos. Algunas gramíneas utilizadas en la dieta de rumiantes en esta zona, no tiene la capacidad de suministrar lo niveles apropiados de amonio para los microorganismos en el rumen, que permitan una actividad adecuada, teniendo como prioridad la optimización de la fermentación y digestión de forrajes, la cual se puede lograr con la introducción de especies forrajeras arbóreas y arbustivas, especialmente leguminosas para suplementar los animales, considerando cuidadosamente la disposición suficiente de los nutrientes para suplir los requerimientos del animal. OBJETIVO. Determinar el potencial de uso integral de las especies forrajeras arbustivas: Tithonia diversifolia (botón de oro) (Td) Cratylia argentea (veranera) (Ca), Acalypha diversifolia (Ad) y macrostachia (varejuana) (Am) y arbóreas:
\end{abstract}


Gmelina arbórea (melina) (Ga) y Moringa oleífera (moringa) (Mo), en aplicaciones de Agroforestería. MATERIALES Y MÉTODOS. Estas especies se establecieron en el Piedemonte Llanero, vereda Barcelona, Departamento del Meta, para lo cual se hicieron parcelas con cinco (5) surcos separados, un metro con plantas sembradas a una distancia de 0,5 metros, con 25 plantas por parcela, donde se realizó la evaluación y análisis de sus características fenotípicas y agronómicas, de su adaptabilidad, su producción de biomasa, sus análisis bromatológicos y contenido de minerales, durante los primeros 45,60 y 100 días de establecidas y bajo condiciones de corte a los 30, 45 y 60 días, una vez realizada la poda de estandarización. Por otra parte, se evaluaron los cambios en las propiedades químicas, físicas y biológicas del suelo, un año después de su establecimiento. Se corrió un modelo de diseño completamente al azar y en razón de que existieron diferencias significativas, se aplicó la prueba de Tukey para comparación de medias, utilizando el paquete de análisis estadístico SPSS. Statistical Package for the Social Sciences (V. 19). RESULTADOS. Por sus condiciones de adaptabilidad, características fenotípicas, agronómicas y facilidad para su establecimiento (100 días) sobresalieron las especies (Td), (Ca) y (Ga) presentando sobrevivencia del $99.5 \%$, vigores mayores de 3 sobre 5 , coberturas de $86.6 \%$, número de hojas de 132 , relación hoja/tallo del $33 \%$ y mínimo daño por insectos evaluado en 1.1. Una vez se inició el proceso de cortes, estas mismas especies continuaron destacándose obteniendo sobrevivencia del 99\%, vigores mayores a 4 sobre 5 , manteniendo su cobertura inicial, aumentando el número de hojas a 149, la relación hoja/tallo a 31.5 y disminuyendo el daño por insectos a 0.8. Las especies $(\mathrm{Ad})$ y $(\mathrm{Am})$ presentaron un establecimiento inicial lento e irregular, con sobrevivencia de tan solo $55.3 \%$, vigores menores a 3 sobre 5 , coberturas muy densas del $18 \%$, número mínimo de hojas de 43 , relación hoja / tallo del 13.5 y un daño de insectos también inapreciable de 1,5. Una vez sometidas a los diferentes cortes, su respuesta a estos fue mantenerse con las características iniciales., inclusive tendieron a desaparecer en el ecosistema estudiado. En cuanto a la producción de biomasa, la especie (Td) se destacó de las demás con promedio de 13.12 Ton /ha / materia fresca, equivalente a 2.48 
Ton/ha/materia seca y de 1.2 Ton /ha de hoja seca, cada 60 días, pudiéndose realizar por lo menos cuatro cortes al año bajo las condiciones del agro ecosistema evaluado. La especie (Ga) le siguió con promedio de 5.17 Ton /ha / materia fresca, equivalente a $1.51 \mathrm{Ton} / \mathrm{ha} / \mathrm{materia}$ seca y de $0.83 \mathrm{Ton} / \mathrm{ha}$ de hoja seca. Las especies ( $\mathrm{Ca}$ ) y ( $\mathrm{Ad}$ ) obtuvieron promedios de 1.7 Ton /ha / materia fresca, equivalente a $0.66 \mathrm{Ton} / \mathrm{ha} / \mathrm{materia}$ seca y de $0.43 \mathrm{Ton} / \mathrm{ha}$ de hoja seca, siendo estas muy inferiores en la especie (Am). Los forrajes evaluados presentan contenidos bromatológicos que permitirían su utilización en la alimentación de animales, especialmente rumiantes. Su alto contenido proteico y alta digestibilidad supera a los forrajes comúnmente utilizados en el trópico llegando a ser comparables incluso con los concentrados utilizados comúnmente. Las especies (Ad) y (Am) obtuvieron el mayor porcentaje de materia seca, $40.32 \%$ y la mayor relación Carbono / Nitrógeno $41.76 \%$, mientras que las especies $(\mathrm{Ca}),(\mathrm{Ga})$ y $(\mathrm{Td})$ obtuvieron $33.8,29.9$ y $19.5 \%$ de materia seca respectivamente y relaciones del $26.8,30$ y 25.3 correspondientemente. Es de anotar como (Td), (Ca) y (Ga) obtuvieron proteínas mayores del $20 \%$, con promedios de 22.10 , digestibilidades $62.6 \%$. Las especies (Ad) y (Am) no obtuvieron proteínas tan altas, $15 \%$, pero sus digestibilidades fueron del orden del $75.7 \%$, sobresaliendo también con tan solo $26.9 \%$ de FDN y 20.1 de FDA. Los demás forrajes evaluados obtuvieron de $42.6 \%$ de FDN y de 32.2 de FDA. En cuanto al contenido de grasa sobresale (Am) con $4.7 \%$, mientras que las demás contienen en promedio de $2.4 \%$. \% respectivamente. (Ga), $(A m)$ y $(A d)$ sobresalen en el aporte de ENN y NDT con el 58.4 y $76.1 \%$ respectivamente, mientras que las demás aportan 42,4 de ENN y 67.8 de NDT. Los aportes de nutrientes no digestibles fueron menores en las especies $(A m)$ y $(A d)$. Estas forrajeras contribuyen con $3.58 \mathrm{Megacal} / \mathrm{Kg} / \mathrm{MS}$ de $\mathrm{EB}, 3.2$ de ED y 2.65 de EM. Las especies evaluadas favorecerían en gran parte a suplir la falta de minerales aportados por las gramíneas en pastoreo utilizadas en los sistemas de producción animal del medio, aumentando los índices productivos y reproductivos del sistema, ya que estas tendrían la capacidad de convertirse en parte fundamental de la dieta de los animales sobretodo en épocas de crisis. Las especies analizadas nos aportaran un alto nivel de calcio que va desde 3.69 a 
$1.26 \%$, promedio de 2.8 y de magnesio que va desde 0.42 a 0.72 , media de $0.49 \%$. En cuanto al fósforo, $(\mathrm{Ga})$ ofrecería el más alto valor, $0.88 \%$. En cuanto al potasio por parte de estas especies es relativamente bajo, promedio de $1.5 \%$. Dentro de los microminerales, se destaca el del hierro de (Am), 468 ppm y de boro en todas las especies, que va de 25.6 a 47.4 ppm. En cuanto a cobre y azufre es bajo en todas. Los demás microminerales están dentro de los rangos aceptables. Las especies $(\mathrm{Td}),(\mathrm{Ca})$ y $(\mathrm{Ga})$ toleraron las condiciones de baja fertilidad natural y la alta concentración de aluminio de los suelos ácidos del ecosistema evaluado, además contribuyeron, a pesar del poco tiempo evaluado, de manera efectiva a que en los suelos donde se establecieron se presentaran cambios benéficos tanto químicos, físicos y biológicos que aumentaron la disponibilidad de los nutrientes y por ende su fertilidad. Los suelos establecidos con $(\mathrm{Ga})$, aumentaron el contenido de fósforo de 12.5 a 16.7 ppm. Los suelos con (Ca), presentaron los mayores cambios así, disminuyeron el contenido de aluminio de 1.2 a $0.95 \mathrm{meq} / 100 \mathrm{gr}$, por ende la saturación de 32.7 a $26.2 \%$, aumentaron el contenido de calcio de 1.78 a $2.25 \mathrm{meq} / 100 \mathrm{gr}$ y la saturación de bases de 67.3 a $73.8 \%$. Es importante anotar como todos los suelos implantados con estas especies ampliaron su porosidad pasando de $20.9 \%$ a un promedio de $32.7 \%$, provocando que estos suelos se produjera un efecto de descompactación, siendo mayor en el suelo con (Ca), seguida de $(\mathrm{Ga})$, y $(\mathrm{Td})$. Además, estos suelos presentaron mayor producción de necromasa pasando de $0.2 \mathrm{~T} / \mathrm{ha}$ a 1 con $(\mathrm{Td})$, a $5.2 \mathrm{con}(\mathrm{Ca})$ y a $4.4 \mathrm{con}(\mathrm{Ga})$, sin presentarse, probablemente por el corto tiempo evaluado, cambios en el contenido de materia orgánica, nitrógeno y carbono. De igual manera se estimuló la disminución de la temperatura en los suelos establecidos con las especies, así: a nivel $0 \mathrm{~cm}$ disminuyó de 28.6 a $26.4^{\circ} \mathrm{C}$, a los $10 \mathrm{~cm}$ de profundidad de 26.3 a 25.6 ${ }^{\circ} \mathrm{C}$ y a los $20 \mathrm{~cm}$ de 28.6 a $26^{\circ} \mathrm{C}$. Bajo las condiciones del estudio, la especie moringa (Moringa oleífera), no pudo ser evaluada debido a que fue imposible establecerla. CONCLUSIONES: Las especies analizadas en el presente estudio, tienen un gran potencial para ser usadas como componentes del sistema en Agroforestería, es así como, contribuirían en los sistemas agrosilvopastoriles ya que podrían ser utilizadas unas como cercas vivas, otras como bancos de proteína 
bajo pastoreo o en sistemas de conservación de forraje e inclusive bajo pastoreos directos. Se demostró que pueden llegar a favorecer la conservación de los recursos naturales mejorando las propiedades físicas y biológicas del suelo, conservando la vegetación, el agua y proporcionando gran beneficio para la conservación de la biodiversidad. Por otra parte, darían la posibilidad a los pequeños productores de percibir otros ingresos, ya que son alternativas económicas y ecológicas viables. Se debe dar continuidad a los procesos de identificación, caracterización y potencial de uso integral de especies arbóreas y arbustivas con potencial forrajero, no solo en la región del estudio, sino para los diferentes agro ecosistemas de la Orinoquia colombiana ( altillanura plana, serranía y altillanura inundable). Aprovechar el conocimiento tradicional de las comunidades rurales que tienen sobre los recursos naturales forrajeros de cada región que con un manejo adecuado y técnico, podrían ser aprovechados en la nutrición animal.

Palabra clave: Tithonia diversifolia; Cratylia argentea; Acalypha diversifolia y macrostachia; Gmelina arbórea; Moringa oleífera.

\section{ABSTRACT}

The main problems to increase productivity in ruminant production systems are: 1 . Limited quantity and quality of the forage on offer, particularly in the dry season, which is reflected in a poor contribution of total digestible nutrients generating, low fermentation microbial with little flow and absorption of them in the animal's posterior tract, especially the protein, which negatively affects food conversion; 2. Lack of genetic potential to produce milk and 3. Poor management of herds. Some grasses used in the diet of ruminants in this area, do not have the ability to provide the appropriate levels of ammonium for microorganisms in the rumen, which allow adequate activity, with priority being the optimization of fermentation and digestion of forages, the which can be achieved with the introduction of tree and shrub 
fodder species, especially legumes to supplement the animals, carefully considering the sufficient disposition of nutrients to meet the animal's requirements. OBJECTIVE. Determine the potential for integral use of shrub fodder species: Tithonia diversifolia (golden button) (Td) Cratylia argentea (veranera) (Ca), Acalypha diversifolia (Ad) and macrostachia (varejuana) (Am) and arboreal: Tree Gmelina (melina) (Ga) and Moringa oleifera (moringa) (Mo), in Agroforestry applications. MATERIALS AND METHODS. These species were established in the Piedemonte Llanero, Barcelona sidewalk, Department of Meta, for which plots were made with five (5) separate rows, one meter with plants planted at a distance of 0.5 meters, with 25 plants per plot, where the evaluation and analysis of its phenotypic and agronomic characteristics, its adaptability, its biomass production, its bromatological analyzes and mineral content, during the first 45, 60 and 100 days established and under cutting conditions at 30,45 and 60 days, once the pruning of standardization. On the other hand, changes in the chemical, physical and biological properties of the soil were evaluated, one year after its establishment. A completely randomized design model was run and because there were significant differences, the Tukey test was applied to compare means, using the SPSS statistical analysis package. Statistical Package for the Social Sciences (V. 19). RESULTS Due to its adaptability conditions, phenotypic, agronomic characteristics and ease of establishment (100 days), the species (Td), (Ca) and (Ga) stood out, presenting survival of $99.5 \%$, vigores greater than 3 out of 5 , coverage of $86.6 \%$, number of leaves of 132 , leaf / stem ratio of $33 \%$ and minimum insect damage evaluated in 1.1. Once the cutting process began, these same species continued to stand out, obtaining survival of $99 \%$, vigores greater than 4 out of 5 , maintaining their initial coverage, increasing the number of leaves to 149 , the leaf / stem ratio to 31.5 and decreasing the insect damage at 0.8 . The species (Ad) and (Am) presented a slow and irregular initial establishment, with survival of only $55.3 \%$, vigores less than 3 out of 5 , very dense coverage of $18 \%$, minimum number of leaves of 43 , leaf / stem ratio of 13.5 and an insect damage also negligible of 1.5. Once submitted to the different cuts, their response to these was to maintain the initial characteristics. They even tended to disappear in the 
ecosystem studied. Regarding biomass production, the species (Td) stood out from the others with an average of 13.12 Ton / ha / fresh matter, equivalent to 2.48 Ton / ha / dry matter and 1.2 Ton / ha of dry leaf, every 60 days, being able to make at least four cuts a year under the conditions of the agro ecosystem evaluated. The species (Ga) followed with an average of 5.17 Ton / ha / fresh matter, equivalent to 1.51 Ton / ha / dry matter and 0.83 Ton / ha of dry leaf. The species (Ca) and (Ad) obtained averages of 1.7 Ton / ha / fresh matter, equivalent to 0.66 Ton / ha / dry matter and 0.43 Ton / ha of dry leaf, being these much lower in the species (Am). The forages evaluated have bromatological contents that would allow their use in the feeding of animals, especially ruminants. Its high protein content and high digestibility exceed the forages commonly used in the tropics, becoming comparable even with the commonly used concentrates. Species (Ad) and (Am) obtained the highest percentage of dry matter, $40.32 \%$ and the highest Carbon / Nitrogen ratio $41.76 \%$, while species $(\mathrm{Ca}),(\mathrm{Ga})$ and $(\mathrm{Td})$ obtained 33.8, 29.9 and $19.5 \%$ of dry matter respectively and ratios of $26.8,30$ and 25.3 correspondingly. It should be noted that $(\mathrm{Td}),(\mathrm{Ca})$ and $(\mathrm{Ga})$ obtained proteins greater than $20 \%$, with averages of 22.10 , digestibility $62.6 \%$. The species (Ad) and (Am) did not obtain such high proteins, $15 \%$, but their digestibilities were of the order of $75.7 \%$, also excelling with only $26.9 \%$ of FDN and 20.1 of FDA. The other evaluated forages obtained $42.6 \%$ of FDN and 32.2 of FDA. As for the fat content, it stands out $(\mathrm{Am})$ with $4.7 \%$, while the others contain an average of $2.4 \%$. \% respectively. (Ga), (Am) and (Ad) stand out in the contribution of ENN and NDT with 58.4 and $76.1 \%$ respectively, while the others contribute 42.4 of ENN and 67.8 of NDT. The contributions of non-digestible nutrients were lower in species (Am) and (Ad). These forage plants contribute 3.58 Megacal / Kg / MS of EB, 3.2 of ED and 2.65 of EM. The species evaluated would greatly favor the lack of minerals provided by grazing grasses used in animal production systems of the environment, increasing the productive and reproductive rates of the system, since these would have the ability to become a fundamental part of The diet of animals especially in times of crisis. The analyzed species will provide us with a high level of calcium that goes from 3.69 to $1.26 \%$, average of 2.8 and magnesium that goes from 0.42 to 0.72 , 
average of $0.49 \%$. As for phosphorus, $(\mathrm{Ga})$ would offer the highest value, $0.88 \%$. As for potassium by these species, it is relatively low, an average of $1.5 \%$. Within the microminerals, the iron of (Am), $468 \mathrm{ppm}$ and boron in all species, ranging from 25.6 to $47.4 \mathrm{ppm}$. As for copper and sulfur it is low in all. The other microminerals are within the acceptable ranges. The species $(\mathrm{Td}),(\mathrm{Ca})$ and $(\mathrm{Ga})$ tolerated the conditions of low natural fertility and the high concentration of aluminum in the acidic soils of the ecosystem evaluated, also contributed, despite the short time evaluated, effectively so that in Soils where they were established will be beneficial changes both chemical, physical and biological that increased the availability of nutrients and therefore their fertility. The soils established with $(\mathrm{Ga})$, increased the phosphorus content from 12.5 to $16.7 \mathrm{ppm}$. Soils with $(\mathrm{Ca})$, presented the greatest changes as well, decreased the aluminum content from 1.2 to $0.95 \mathrm{meq} / 100 \mathrm{gr}$, therefore saturation from 32.7 to $26.2 \%$, increased the calcium content from 1.78 to $2.25 \mathrm{meq} / 100 \mathrm{gr}$ and base saturation from 67.3 to $73.8 \%$. It is important to note how all soils implanted with these species expanded their porosity from $20.9 \%$ to an average of $32.7 \%$, causing these soils to produce a decompaction effect, being greater in the soil with ( $\mathrm{Ca}$ ), followed by ( $\mathrm{Ga}$ ), and (Td). In addition, these soils showed greater production of necromass, going from $0.2 \mathrm{~T}$ / ha to 1 with (Td), 5.2 with ( $\mathrm{Ca}$ ) and 4.4 with $(\mathrm{Ga})$, without presenting, probably for the short time evaluated, changes in the content of organic matter, nitrogen and carbon. Similarly, the temperature decrease in the soils established with the species was stimulated, as follows: at a level of $0 \mathrm{~cm}$ it decreased from 28.6 to $26.4^{\circ} \mathrm{C}$, at a depth of 10 $\mathrm{cm}$ from 26.3 to $25.6^{\circ} \mathrm{C}$ and at $20 \mathrm{~cm}$ from 28.6 at $26^{\circ} \mathrm{C}$. Under the conditions of the study, the moringa species (Moringa oleífera) could not be evaluated because it was impossible to establish it. CONCLUSIONS: The species analyzed in the present study have great potential to be used as components of the Agroforestry system, which is how they would contribute to agrosilvopastoral systems since they could be used as live fences, others as grazing protein banks or in forage conservation systems and even under direct grazing. It was shown that they can favor the conservation of natural resources by improving the physical and biological properties of the soil, conserving vegetation, water and providing great 
benefits for the conservation of biodiversity. On the other hand, they would give small producers the possibility of receiving other income, since they are viable economic and ecological alternatives. The processes of identification, characterization and potential of integral use of tree and shrub species with forage potential should be given continuity, not only in the study region, but also for the different agro ecosystems of the Colombian Orinoquia (flat loft, mountain range and loft) flooded) To take advantage of the traditional knowledge of the rural communities that they have about the natural fodder resources of each region that with an adequate and technical management, could be used in animal nutrition.

Keyword: Tithonia diversifolia; Cratylia argentea; Acalypha diversifolia and macrostachia; Tree Gmelina; Moringa oleífera 


\title{
Respuesta de peces nativos a la interacción del Glifosato y el surfactante POEA con $\mathrm{CaCO}_{3:}$ ¿Efectos indeseables del encalado + herbicidas sobre ecosistemas acuáticos en la Orinoquia?
}

\section{Response of native fish to the interaction of glyphosate and POEA surfactant with CaCO3: Undesirable effects of liming + herbicides on aquatic ecosystems in the Orinoquia?}

\author{
Pedro René Eslava-Mocha; ; Anyi Liset Vargas Pulido²; Yohana María Velasco- \\ Santamaría ${ }^{3 ;} \&$ Bernardo Baldiserrotto ${ }^{4}$ \\ ${ }^{1} \mathrm{MV}, \mathrm{M}$ Sc. Doctorado en Ciencias Agropecuarias, Universidad de los Llanos, \\ Grupo de investigación GSOA, IALL. \\ ${ }^{2}$ Bióloga, egresada Universidad de los Llanos. \\ ${ }^{3} \mathrm{MV}, \mathrm{MSc}, \mathrm{PhD}$, profesora Asociada, Grupo de investigación BioTox, Universidad \\ de los Llanos. \\ ${ }^{4}$ Department of Physiology and Pharmacology, Universidade Federal de Santa \\ Maria, Brasil, RGS. \\ pedro.eslava@unillanos.edu.co
}

\section{RESUMEN}

En los últimos años en los Llanos Orientales de Colombia se está incrementado la superficie de monocultivos como soya, maíz, arroz, caña de azúcar y palma de aceite que aplican mezclas de herbicidas con base en Glifosato (HBG), aunado al hecho de que en tales sistemas de producción se utiliza con alta frecuencia encalado (ya sea con $\mathrm{CaCO}_{3} \circ \mathrm{Ca}(\mathrm{OH})$ para corregir la acidez y mejorar la fertilidad de los suelos como recomendación agronómica; siendo muy importante efectuar indagaciones sobre los efectos de los cambios en la dureza de las aguas tropicales que puedan recibir residuos de cal y de las mezclas herbicidas, especialmente en cuanto a la interacción con polioxi-etilen-aminas / talowaminas etoxiladas (POEA) que son los principales surfactantes acompañantes de las HBG. Se efectuaron dos ensayos en donde se observó la interacción de HBG con $\mathrm{CaCO}_{3}$, determinando la toxicidad de POEA y Glifosato en cachama blanca Piaractus brachypomus; en el primero, mediante exposición aguda (96 horas) 
con 4 tratamientos y dos réplicas de cada uno: Control (0 mg/L); $\mathrm{CaCO}_{3}(60 \mathrm{mg} / \mathrm{L})$; POEA TA-15 (2,1 mg/L) y POEA - TA15 (2,1 mg/L) + $\mathrm{CaCO}_{3}(60 \mathrm{mg} / \mathrm{L})$, alevinos de cachama blanca $(n=56)$ con peso de $5 \pm 1 \mathrm{~g}$ en contenedores de $60 \mathrm{~L}, 7$ individuos por contenedor, los peces fueron mantenidos en un sistema semiestático con recambio diario del $20 \%$ del volumen de agua. Un segundo ensayo se efectuó mediante exposición crónica por 21 días a dosis sub-letales también bajo un sistema semi-estático en el Laboratorio de Bioensayos del Instituto de Acuicultura de los Llanos; en ese caso se establecieron dos experimentos con 6 tratamientos cada uno: - experimento No. 1. POEA (TA-15) / CaCO3: peces con Longitud estándar $10 \pm 0.9 \mathrm{~cm}$, Peso $38.2 \pm 6.0$ g. $(\mathrm{n}=96): 4$ animales por acuario, 4 repeticiones, 16 animales por tratamiento: Exposición 21 días, observación hasta 50 días. (Muestreo a las 7; 14; 21 y 50 días): Control -sin sustancias experimentales-; $\mathrm{CaCO} 360 \mathrm{mg} / \mathrm{L} ;$ POEA $0.8 \mathrm{mg} / \mathrm{L} ;$ POEA $1.6 \mathrm{mg} / \mathrm{L}$; POEA $0.8 \mathrm{mg} / \mathrm{L} / \mathrm{CaC03} 60 \mathrm{mg} / \mathrm{L}$ \& POEA $1.6 \mathrm{mg} / \mathrm{L} / \mathrm{CaC} 0360 \mathrm{mg} / \mathrm{L}$. y, un experimento No.2. GP / CaCO3: 5 animales por acuario, 4 repeticiones, 20 animales por tratamiento (Longitud estándar $8.0 \pm 0.31 \mathrm{~cm}$. Peso: 35,2 $\pm 5,1$ ( $\mathrm{n}=$ 120)) Exposición 21 días, observación hasta 50 días. (muestreo a los 7; 14; 21 y 49 días) así: Control; $\mathrm{CaCO} 360 \mathrm{mg} / \mathrm{L}$; Glifosato (grado analítico) $10 \mathrm{mg} / \mathrm{Glifosato}$ $20 \mathrm{mg} / \mathrm{L}$; Glifosato $10 \mathrm{mg} / \mathrm{L}+\mathrm{CaC0} 360 \mathrm{mg} / \mathrm{L}$ \& Glifosato $20 \mathrm{mg} / \mathrm{L}$ + CaC03 60 $\mathrm{mg} / \mathrm{L}$. Tanto en el ensayo agudo como en el ensayo crónico la mortalidad, los signos clínicos y las lesiones macro y microscópicas fueron rigurosamente registradas. En la exposición aguda se encontró mayor mortalidad ante el POEA TA15 (2,1 mg/L) $+\mathrm{CaCO}_{3}(60 \mathrm{mg} / \mathrm{L})$ con un $65 \%$ de mortalidad, frente a $50 \%$ en el tratamiento de solo POEA - TA15 (2,1 mg/L) y, ninguna mortalidad en el Control y en la exposición ante solo $\mathrm{CaCO}_{3}(60 \mathrm{mg} / \mathrm{L})$. Peces de la exposición aguda a POEA TA15 presentaron letargo a partir de las primeras 4 horas de exposición, pérdida de comportamiento de cardumen y cambio del patrón de nado después de 8 horas, aumento de la frecuencia opercular y prolapso del labio inferior después de 10 horas, pérdida del eje de nado y posición de los individuos en la columna de agua a partir de las 11 horas. En la interacción $\left(\mathrm{CaCO}_{3} 60 \mathrm{mg} / \mathrm{L}+\mathrm{POEA} 2,1 \mathrm{mg} / \mathrm{L}\right)$ se presentó letargo a partir de las 6 horas, pérdida de la formación en cardumen 
después de 7 horas, cambio del patrón de nado y ascenso de la mitad de los individuos en la posición de la columna de agua con signos de angustia respiratoria a las 9 horas, pérdida del eje de nado, nado errático y prolapso del labio inferior a las 11 horas, concluyendo que la interacción entre el POEA-TA15 y $\mathrm{CaCO}_{3}$ no es favorable para evitar la mortalidad, verificando también lesiones más severas en piel, branquias, hígado y encéfalo de los peces expuestos ante el surfactante en presencia de carbonato de calcio que los expuestos únicamente ante POEA TA15. En los ensayos de exposición crónica se corroboraron las observaciones de la exposición aguda; en este caso hubo mayor mortalidad en los tratamientos de POEA TA-15 en presencia de $\mathrm{CaCO}_{3}$ que en los expuestos solo al surfactante, hallando $10 \%$ de mortalidad a los 21 días en expuestos a $1.6 \mathrm{mg} / \mathrm{L}$ de POEA TA15, en tanto que se encontró un $35 \%$ de mortalidad en los sometidos a POEA $1.6 \mathrm{mg} / \mathrm{L}+\mathrm{CaC0} 360 \mathrm{mg} / \mathrm{L}$ y ninguna mortalidad en los controles. En este caso también las lesiones de piel, branquias, hígado y encéfalo fueron más severas en los sometidos ante la combinación del surfactante y carbonato de calcio. En los ensayos de exposición crónica ante el Glifosato grado técnico y en interacción con carbonato de calcio, no hubo mortalidad en ningún tratamiento; sin embargo, se evidenciaron signos clínicos y lesiones con un mayor grado de severidad bajo los tratamientos combinados de glifosato $+\mathrm{CaCO}$. De otra parte, en todos los casos ocurrió un aumento de la actividad de células de alarma en el sistema nervioso (Mast) tanto en los tratamientos de $\mathrm{CaCO} 3$ solo, o bajo interacción con POEA o con GP con respecto los controles sin ningún compuesto experimental. Los anteriores hallazgos nos llevan a analizar el factor de riesgo que implicaría el aumento de la dureza del agua como componente que puede aumentar la hidrofobicidad y reducir la repulsión electrostática del POEA como se ha descrito en el caso del tensoactivo alquilbenceno-sulfonato lineal en trucha arcoíris hasta tal punto que se aumentó la absorción de este tensoactivo principalmente a través de las branquias (Tolls et al., 2000). En nuestro caso, aparentemente, la mayor toxicidad de POEA observada en la cachama blanca mantenida a una mayor dureza del agua se debería a su mayor absorción provocada por el aumento de la hidrofobicidad y la reducción de la repulsión 
electrostática de POEA. Sin embargo, no se puede descartar que una mayor dureza pueda ser también un factor estresante para esta especie, que es nativa de aguas muy blandas. El estrés causado por una alta dureza del agua podría aumentar la ventilación branquial, aumentando la absorción de POEA y, en consecuencia, su toxicidad. A la luz de estos hallazgos experimentales deberá profundizarse sobre la asociación de $\mathrm{CaCO}_{3}$ y $\mathrm{HBG}$ teniendo en cuenta el encalado y el uso de herbicidas como factores estresores y tóxicos en aguas de cuerpos naturales de la Orinoquia, en este acaso el $\mathrm{CaCO}_{3}$ estaría aumentando el efecto toxico del POEA de las mezclas herbicidas principalmente, aunque ante la exposición de peces ante glifosato solo, también se observaron efectos clínicos y patológicos ante la interacción estudiada.

Palabras clave: Eco-toxicología, Mezclas herbicidas, Glifosato, surfactantes noiónicos, dureza, Interacciones en cuerpos de agua.

\section{ABSTRACT}

In recent years in the Eastern Plains of Colombia, the area of monocultures such as soybeans, corn, rice, sugar cane and palm oil that apply mixtures of glyphosatebased herbicides $(\mathrm{GBH})$ has been increased, coupled with the fact that in Such production systems are used with high frequency liming (either with $\mathrm{CaCO}_{3}$ or $\mathrm{Ca}$ $(\mathrm{OH}))$ to correct acidity and improve soil fertility as an agronomic recommendation; it is very important to make inquiries about the effects of changes in hardness of tropical waters that may receive residues of lime and herbicidal mixtures, especially in terms of interaction with ethoxylated polyoxy-ethylene amines / talowamines (POEA), which are the main surfactants that accompany $\mathrm{GBH}$. Two trials were conducted in which observed the interaction of $\mathrm{HBG}$ with $\mathrm{CaCO}_{3}$, determining the toxicity of POEA and glyphosate in white cachama Piaractus brachypomus; in the first, by acute exposure a (96 hours) trial with 4 treatments and two replicates of each: Control (0 mg / L); $\mathrm{CaCO}_{3}$ (60 mg / L); POEA TA-15 $(2.1 \mathrm{mg} / \mathrm{L})$ and POEA - TA15 (2.1 mg / L) + $\mathrm{CaCO}_{3}(60 \mathrm{mg} / \mathrm{L})$, white cachama fry 
( $\mathrm{n}=56$ ) weighing $5 \pm 1 \mathrm{~g}$ in containers of $60 \mathrm{~L}, 7$ individuals per container, the fish were kept in a semi-static system with daily replacement of $20 \%$ of the volume of water. A second trial was carried out by chronic exposure for 21 days at sub-lethal doses also under a semi-static system in the Bioassay Laboratory of the Institute of Aquaculture of Los Llanos; in that case two experiments were established with 6 treatments each: - experiment No. 1. POEA (TA-15) / $\mathrm{CaCO}_{3}$ : fish with standard Length $10 \pm 0.9 \mathrm{~cm}$, Weight $38.2 \pm 6.0 \mathrm{~g}$. $(\mathrm{n}=96): 4$ animals per aquarium, 4 repetitions, 16 animals per treatment: Exposure 21 days, observation up to 50 days. (sampling at $7 ; 14 ; 21$ and 50 days): Control -without experimental substances-; $\mathrm{CaCO}_{3}$ 60mg / L; POEA 0.8mg / L; POEA 1.6mg / L; POEA 0.8 mg / $\mathrm{L} / \mathrm{CaCO}_{3} 60 \mathrm{mg} / \mathrm{L}$ \& POEA $1.6 \mathrm{mg} / \mathrm{L} / \mathrm{CaCO}_{3} 60 \mathrm{mg} / \mathrm{L}$. and, an experiment No.2. GP / $\mathrm{CaCO}_{3}: 5$ animals per aquarium, 4 repetitions, 20 animals per treatment (Standard length $8.0 \pm 0.31 \mathrm{~cm}$. Weight: $35.2 \pm 5.1(\mathrm{n}=120)$ ) Exposure 21 days, observation up to 50 days. (Sampling at $7 ; 14 ; 21$ and 49 days) as follows: Control; $\mathrm{CaCO}_{3}$ 60mg / L; Glyphosate (analytical grade) $10 \mathrm{mg} /$ Glyphosate $20 \mathrm{mg} / \mathrm{L}$; Glyphosate $10 \mathrm{mg} / \mathrm{L}+\mathrm{CaCO}_{3} 60 \mathrm{mg} / \mathrm{L}$ \& Glyphosate $20 \mathrm{mg} / \mathrm{L}+\mathrm{CaCO}_{3} 60 \mathrm{mg}$ / L. Both in the acute trial and in the chronic trial, mortality, clinical signs, and macro and microscopic lesions were rigorously recorded. In acute exposure, higher mortality was found before the POEA - TA15 $(2.1 \mathrm{mg} / \mathrm{L})+\mathrm{CaCO}_{3}(60 \mathrm{mg} / \mathrm{L})$ with $65 \%$ mortality, compared to $50 \%$ in the treatment of only POEA - TA15 $(2,1 \mathrm{mg} /$ $\mathrm{L})$ and, no mortality in the Control and in exposure to only $\mathrm{CaCO} 3(60 \mathrm{mg} / \mathrm{L})$. Fish from acute exposure to POEA TA15 showed lethargy from the first 4 hours of exposure, loss of school behavior and change of swimming pattern after 8 hours, increased opercular frequency and lower lip prolapse after 10 hours, loss of the swimming axis and position of the individuals in the water column after 11 hours. In the interaction $\left(\mathrm{CaCO}_{3} 60 \mathrm{mg} / \mathrm{L}+\mathrm{POEA} 2.1 \mathrm{mg} / \mathrm{L}\right)$ lethargy was presented after 6 hours, loss of the formation in school after 7 hours, change of the swimming pattern and ascent of half of the individuals in the position of the water column with signs of respiratory distress at 9 o'clock, loss of the swim axis, erratic swim and lower lip prolapse at 11 o'clock, concluding that the interaction between the POEATA15 and $\mathrm{CaCO}_{3}$ is not favorable to avoid mortality, also verifying more severe 
lesions in skin, gills, liver and brain of the fish exposed to the surfactant in the presence of calcium carbonate than those exposed only to POEA TA15. In chronic exposure trials, observations of acute exposure were corroborated; in this case there was a higher mortality in the treatments of POEA TA-15 in the presence of $\mathrm{CaCO}_{3}$ than in those exposed only to the surfactant, finding $10 \%$ mortality at 21 days in those exposed to $1.6 \mathrm{mg} / \mathrm{L}$ of POEA TA15, while found a $35 \%$ mortality in those under POEA 1.6mg / L + $\mathrm{CaCO}_{3} 60 \mathrm{mg} / \mathrm{L}$ and no mortality in the controls. In this case also the skin, gill, liver and brain lesions were more severe in those submitted to the combination of the surfactant and calcium carbonate. In the trials of chronic exposure to glyphosate technical grade and in interaction with calcium carbonate, there was no mortality in any treatment; however, clinical signs and lesions with a greater degree of severity were evidenced under the combined treatments of glyphosate $+\mathrm{CaCO}_{3}$. On the other hand, in all cases there was an increase in the activity of alarm cells in the nervous system (Mast) both in $\mathrm{CaCO}_{3}$ treatments alone, or under interaction with POEA or with GP regarding controls without any experimental compound. The previous findings lead us to analyze the risk factor that would imply the increase in water hardness as a component that could increase the hydrophobicity and reduced the electrostatic repulsion of the POEA as described in the case of the linear alkylbenzene sulphonate surfactant up to that point that the absorption of this surfactant was increased mainly through the gills) in rainbow trout (Tolls et al., 2000). In our case, apparently, the greater toxicity of POEA observed in the white cachama maintained at a greater hardness of the water would be due to its greater absorption caused by the increase in hydrophobicity and the reduction of the electrostatic repulsion of POEA. However, it cannot be ruled out that greater hardness can also be a stressful factor for this species, which is native to very soft waters. Stress caused by high water hardness could increase gill ventilation, increasing the absorption of POEA and, consequently, its toxicity. In light of these experimental findings, the association of $\mathrm{CaCO}_{3}$ and $\mathrm{GBH}$ should be deepened taking into account liming and the use of herbicides as stressors and toxic factors in waters of natural bodies of the Orinoquia, in this case the $\mathrm{CaCO}_{3}$ would be increasing the toxic effect of the POEA 
of the herbicidal mixtures mainly, although in the presence of fish only with glyphosate clinical and pathological effects were observed under the interaction studied.

Keyword: Ecotoxicology, Herbicidal mixtures, Glyphosate, Non-ionic surfactants, hardness, Interactions in natural water bodies. 


\section{CIENCIAS ANIMALES}

\section{Crioconservación seminal de cachama negra Colossoma macropomum como estrategía de producción y conservación de recursos genéticos}

\section{Seminal cryopreservation of black cachama Colossoma macropomum as a strategy for production and conservation of genetic resources}

Víctor Mauricio Medina-Robles, Leydy Yasmin. Sandoval-Vargas, Diana Nathalie Guaje-Ramírez, Laura Cristina Marin-Cossio; Pablo Emilio Cruz-Casallas Grupo de Investigación sobre Reproducción y Toxicología de Organismos Acuáticos - GRITOX, Instituto de Acuicultura de los Llanos - IALL, Facultad de Ciencias Agropecuarias y Recursos Naturales, Universidad de los Llanos, Villavicencio, Meta - Colombia vmmedinarobles@unillanos.edu.co

\section{RESUMEN}

INTRODUCCIÓN La Cachama negra (Colossoma macropomum) es un pez nativo de Sur América. En Colombia, no hay estudios sobre protocolos estandarizados para su crioconservación seminal. La implementación de estás biotecnologías permitirían su producción comercial continua e introducción en bancos de recursos genéticos. OBJETIVO El objetivo del presente estudio fue evaluar los efectos de la crioconservación sobre el semen de $C$. macropomum sometido a diferentes crioprotectores y sistemas de empaque con miras a consolidar un protocolo eficiente de crioconservación para la especie. MATERIALES Y MÉTODOS Se utilizó semen de tres machos sexualmente maduros $(4.6 \pm 1.6 \mathrm{~kg})$. El semen fue diluido en una proporción 1:4 usando tres diferentes agentes crioprotectores (Dimetilsulfoxido 10\% [DMSO], Metanol 10\% [MET], Etilenglicol 5\% [ETG]) con o sin la inclusión de yema de huevo $12 \%(\mathrm{YH})$; a su vez a cada diluyente fue adicionada glucosa $5.5 \%$. Además, fueron evaluados dos sistemas de empaque 
(pajillas de $0.5 \mathrm{ml}$ y macrotubos de $2.0 \mathrm{ml}$ ). Las pajillas y macrotubos fueron expuestas a vapores de nitrógeno líquido $(\mathrm{NL})$ y luego almacenadas durante 8 meses. El semen fue descongelado en baño de agua a $37^{\circ} \mathrm{C}$ por 60 seg y determinada la motilidad masal (\%) [MM], duración de la motilidad (seg) [DM], integridad de membrana plasmática (\%) [IMP] y fertilidad (\%). RESULTADOS La motilidad postdescongelación en todos los tratamientos fue significativamente diferente $(P<0,05)$ al control siendo MET $2.0 \mathrm{ml}$ el mejor $(53 \pm 5.8 \%)$. La DM tuvo un comportamiento similar para todos los tratamientos siendo solo diferente significativamente para $\mathrm{ETG}+\mathrm{YH} 0.5 \mathrm{ml}$ comparado con el control. La IMP se mantuvo sin diferencias significativas con respecto al control en MET $2.0 \mathrm{ml}$. La fertilidad fue significativamente menor en la mayoría de tratamientos con $\mathrm{YH}$, siendo MET 2.0ml el mejor (94.7 $\pm 0.6 \%$ ). CONCLUSIÓN El semen de Colossoma macropomum es susceptible de crioconservación no siendo necesaria la utilización de $\mathrm{YH}$ en los diluyentes.

AGRADECIMIENTOS. El presente trabajo es apoyado por el Fondo Social de Educación Superior de la Gobernación del Meta a través de la beca de doctorado otorgada al autor Víctor Mauricio Medina-Robles.

Palabras clave: crioconservación, peces nativos, semen, tambaqui.

\begin{abstract}
INTRODUCTION Cachama Negra (Colossoma Macropomum) it's a native fish of South America. In Colombia, there are still no studies on standardized protocols about their seminal cryopreservation. The implementation of these biotechnologies would allow their continuous commercial production and introduction in genetic resources banks. OBJECTIVE The objective of the present study is to evaluate the effects of cryopreservation on C. Macropomum sperm subjected to different cryoprotectants and packaging systems, in order to consolidate an efficient cryopreservation protocol for this species. MATERIALS AND METHODS Semen from three sexually mature males $(4.6 \pm 1.6 \mathrm{~kg})$ was used. The semen was diluted
\end{abstract}


in a 1:4 ratio using three different cryoprotective agents (Dimethylsulfoxide 10\% [DMSO], Methanol 10\% [MET], Ethylene glycol 5\% [ETG]); with or without 12\% egg yolk $(\mathrm{YH})$, to each diluent was added $5.5 \%$ glucose. In addition, two packing systems were evaluated $(0.5 \mathrm{ml}$ straws and $2.0 \mathrm{ml}$ macrotubes). The straws and macrotubes were exposed to vapors of liquid nitrogen $(\mathrm{NL})$ and then stored for 8 months. The semen was thawed in a water bath at $37^{\circ} \mathrm{C}$ for $60 \mathrm{sec}$ and determined mass motility (\%) [MM], motility duration (sec) [DM], plasma membrane integrity (\%) [IMP] and fertility (\%). RESULTS Post-thaw motility in all treatments was significantly different $(p<0.05)$ to control, being MET $2.0 \mathrm{ml}$ the best $(53 \pm$ $5.8 \%)$. The DM had a similar behavior for all treatments being only significantly different for $\mathrm{ETG}+\mathrm{YH} 0.5 \mathrm{ml}$ compared to the control. The IMP remained without significant differences in respect to the control in MET $2.0 \mathrm{ml}$. Fertility was significantly lower in the majority of treatments based on $\mathrm{YH}$, being MET 2.0ml the best (94.7 $\pm 0.6 \%$ ). CONCLUSION Semen of Colossoma macropomum is susceptible to cryopreservation and the use of $\mathrm{YH}$ in diluents is not necessary.

ACKNOWLEDGMENT. The present work is supported by the Social Fund of Higher Education of the Government of Meta through the doctorate scholarship granted to the author Víctor Mauricio Medina-Robles.

Key words: cryopreservation, native fish, semen, tambaqui. 


\section{Efecto del grado de herencia de vacas sanmartinero sobre el intervalo entre partos y edad al primer parto}

\section{Effect of the degree of inheritance of cows sanmartinero on the interval between births and age at first birth}

Marín Rincón Yelixa Katerine ${ }^{1}$, Rincón Huérfano Luisa Fernanda ${ }^{1}$, Cárdenas García Dario², Lopera-Vásquez Ricaurte ${ }^{3}$, Martínez Correal Germán ${ }^{4}$.

${ }^{1}$ Estudiante de Medicina Veterinaria y Zootecnia. Universidad Cooperativa de Colombia - Sede Villavicencio.

${ }^{2}$ MVZ MSc PhD. Docente de Medicina Veterinaria y Zootecnia. Universidad Cooperativa de Colombia.

${ }^{3}$ MVZ MSc PhD. Docente de Medicina Veterinaria y Zootecnia. Universidad Cooperativa de Colombia. Grupo de investigación IMPRONTA.

${ }^{4}$ MV MSc PhD. Presidente Asocriollanos. yelixa.marinr@campusucc.edu.co luisa.rinconh@campusucc.edu.co dario.cardenas@campusucc.edu.co ricaurte.lopera@campusucc.edu.co germanmartinez@ganadocriollo-colombiano.com

\section{RESUMEN}

INTRODUCCIÓN. El ganado bovino criollo Sanmartinero al igual que todas las razas criollas colombianas se encuentra en riesgo de extinción y dados sus extraordinarios rasgos de adaptación, producción sostenible y competitiva, no debemos ahorrar esfuerzos en su conservación, uso racional y sostenible con miras a hacer más eficiente y competitiva la cría comercial de carne, especialmente en la región de la Orinoquía Colombiana. OBJETIVO. Medir el efecto del grado de herencia de la raza Sanmartinero (SM), en un hato comercial Cebuino (Brahman) sometido a cruzamiento absorbente con toros criollos SM, en el municipio de Vistahermosa (Meta), sobre parámetros reproductivos de intervalo entre partos (IEP) y edad al primer parto (EPP). MATERIALES Y MÉTODOS. Se utilizaron 399 registros productivos de hembras bovinas con diferentes grados de herencia de $\operatorname{SM}(0,25,50,63$ y 75\%), tomados en la finca Cachicamos, 
correspondientes a los años 2004 a 2018, a los cuales se les evaluó la EPP y el IEP (días). Se utilizó un Análisis de varianza de una vía con ayuda de paquete InfoStat ${ }^{\circledR}$. RESULTADOS: Los valores para IEP presentaron un promedio de $436,7 \pm 7,58$ días, en donde los mas altos correspondieron al $25 \%(458.5 \pm 26.4)$ y los mas bajos a $50 \%(428.8 \pm 12.6)$, sin presentar diferencias entre grupos ( $p>0.05)$. El promedio de EPP fue de $1128,7 \pm 28,3$ días, en donde los valores más altos fueron $0 \%$ y $25 \%$ de SM $(1350,8 \pm 57,9$ y $1293,9 \pm 136,3 ; p=0.98$ respectivamente), y al compararles con los mas bajos $50 \%$ y $63 \%(1083,4 \pm 40,1$ y $970 \pm 38,4 ; p=0.0095$ y 0.0007 respectivamente), al igual existió diferencia entre el 0 y $75 \%$ (1094,8 $\pm 61.0 \quad p=0.0416)$. CONCLUSIONES. Las diferencias altamente significativas a valores más bajos EPP, reflejan las ventajas del SM en términos de precocidad y fertilidad en estadios iniciales de producción en hembras, lo que confirma su competitividad y adaptación al medio, que le confieren ventajas en sostenibilidad y rentabilidad en términos económicos al compararlo con otras razas introducidas.

Palabra clave: hembras, genética, cruzamiento, Sanmartinero, parámetros, reproductivos.

\section{ABSTRACT}

INTRODUCTION. Sanmartinero Creole cattle, like as all Colombian Creole breeds, are at risk of extinction and given their extraordinary characteristics of adaptation, sustainable and competitive production, we should not save efforts in their conservation, rational and sustainable use with a view to making them more efficient and competitive commercial beef farming, especially in the region of the Colombian Orinoquía. OBJECTIVE. To Measure the effect of the degree of inheritance of the Sanmartinero (SM) breed, in a Cebu commercial herd (Brahman) undergoing absorbent crossing with SM Creole bulls, in the municipality of Vistahermosa-Meta, on reproductive parameters of interval between births (IEP by its acronym in Spanish) and age at first birth (EPP acronym in Spanish).

MATERIALS AND METHODS. 399 productive records of bovine females with 
different degrees of inheritance of $\operatorname{SM}(0,25,50,63$ and $75 \%)$ were used, which were taken at the Cachicamos farm corresponding to the years 2004 to 2018, of which they were evaluated EPP and IEP (days). A one-way analysis of variance was used with the help of an InfoStat ${ }^{\circledR}$ package. RESULTS: The values for IEP presented an average of $436.7 \pm 7.58$ days, where the highest corresponded to

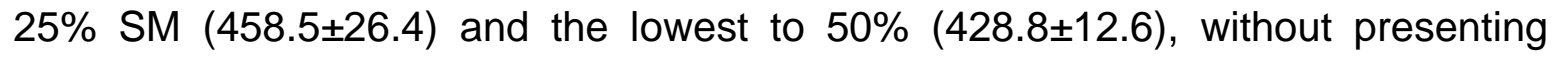
differences between groups ( $p>0.05$ ). The average EPP was $1128.7 \pm 28.3$ days, where the highest values were $0 \%$ and $25 \%$ of SM $(1350.8 \pm 57.9$ and $1293.9 \pm 136.3 ; p=0.98$ respectively), and at compare them with the lowest $50 \%$ and $63 \%(1083.4 \pm 40.1$ and $970 \pm 38.4 ; p=0.0095$ and 0.0007 respectively), likewise there was a difference between 0 and $75 \% \quad(1094.8 \pm 61.0 \quad \mathrm{p}=0.0416)$. CONCLUSIONS. The highly significant differences at lower EPP values reflect the advantages of SM in terms of precocity and fertility in initial stages of production in females, which confirms its competitiveness and adaptation to the environment, which give it advantages in sustainability and profitability in economic terms when compared to other introduced breeds.

Key Words: Males, genetics, Crossbreeds, Sanmartinero, reproductive parameters 


\section{Cerdos a campo abierto: efectos sobre las características de un suelo del piedemonte llanero}

\section{Pigs in the open field: effects on the characteristics of a flatland}

Suescún Ospina Sandra Tatiana¹, Ocampo Duran Álvaro² \& Bolívar Sierra Andrés Felipe $^{3}$

${ }^{1}$ Médico Veterinario y Zootecnista Esp. MSc Docente de la Universidad de los Llanos, Grupo de Investigación en Producción Tropical Sostenible.

2 Zootecnista MSc, PhD Docente de la Universidad de los Llanos, Grupo de Investigación en Producción Tropical Sostenible.

${ }^{3}$ Médico Veterinario y Zootecnista. Universidad de los Llanos, Grupo de Investigación en Producción Tropical Sostenible.

stsuescun@unillanos.edu.co

aocampo@unillanos.edu.co

andres.bolivar@unillanos.edu.co

\section{RESUMEN}

INTRODUCCIÓN. El sistema de producción de cerdos a campo abierto es una alternativa a la producción intensiva orientado a la producción orgánica, o como sistema de bajo costo para pequeños y medianos productores. Este sistema tiene efectos positivos sobre la fertilidad del suelo como producto de la deposición natural de nutrientes por las excretas porcinas, una ventaja potencial que ha sido poco explorada. OBJETIVO. Evaluar los efectos de un sistema de cría de cerdos a campo abierto sobre las condiciones fisicoquímicas y biológicas de un suelo de terraza alta en el piedemonte del Meta. MATERIALES Y MÉTODOS. Este proyecto se realizó en Villavicencio, Meta, se utilizaron 6 cerdas de cría, fueron mantenidas a campo en lotes de $450 \mathrm{~m}^{2}$ y $150 \mathrm{~m}^{2}$ por hembra, (T1, 22 cerdas/ha y T2, 66 cerdas/ha, respectivamente). Se uso como testigo un lote dedicado a la ganadería bovina, bajo manejo tradicional (T3). El ensayo se extendió desde mayo de 2011 hasta abril de 2013. Las cerdas fueron alimentadas con recursos de alta disponibilidad local, siendo el aceite crudo de palma la base energética y torta de 
soya la base proteica, según Ocampo (2002). Los lotes fueron manejados de forma alternada con 30 días de ocupación y 30 días de descanso. Se monitoreó los cambios de las condiciones fisicoquímicas y biológicas de los suelos y los cambios en la composición florística de los lotes antes, durante y después de la ocupación (muestreos repetidos en intervalos de 6 meses en cada uno de los lotes). Se evaluó materia orgánica, contenido de carbono, $\mathrm{pH}$, nitrógeno, fósforo, aluminio, capacidad de intercambio catiónico, compactación y producción de biomasa. El análisis estadístico incluyó pruebas de normalidad y homosedasticidad, así como pruebas de Levene para homogeneidad de varianzas y $t$-Student para variables independientes. RESULTADOS. Se observaron diferencias significativas $(P<0,005)$ en los porcentajes de materia orgánica $(M O)$, contenidos de nitrógeno $(\mathrm{N})$ y carbono del suelo $(\mathrm{C})$ según tratamiento. El tratamiento 1 (450 $\mathrm{m}^{2} /$ animal) generó mayores efectos sobre el porcentaje de materia orgánica $(6,91 \pm 2,16)$, nitrógeno $(138,25 \pm 43,23)$ y carbono del suelo $(2,45 \pm 1,08)$, en comparación con los tratamientos 2 (150 $\mathrm{m}^{2} /$ animal) y 3 (ganadería). De la misma forma, el tiempo de ocupación generó resultados en las variables $\mathrm{MO}, \mathrm{N}, \mathrm{C}, \mathrm{P}$ y producción de biomasa, siendo superiores en los lotes bajo T1 en el segundo año de ocupación. CONCLUSIONES. La ocupación del suelo con cerdas de cría a densidades de $450 \mathrm{~m}^{2} /$ cerda generó aportes significativos de nutrientes, sobre todo nitrógeno (160 Kg/ha); condición que podría ser aprovechada para la producción de forraje para la alimentación cerdos, otras especies animales o cultivos agrícolas.

Palabra clave: Cerdas a campo, cría de cerdos, suelo.

\section{ABSTRACT}

INTRODUCTION The outdoor pig production is an alternative to intensive production system lead to the organic production, or as a low-cost system for small and medium producers. This system has positive effects on soil fertility as a result 
of the natural deposition of nutrients by pig excreta, a potential advantage that has been little explored. OBJECTIVE To evaluate the effects of an outdoor pig production system on the physicochemical and biological conditions of a high terrace soil in the Piedemonte landscape of Meta. MATERIALS AND METHODS This project was carried out in Villavicencio, Meta, 6 breeding sows were used, they were kept in outdoor in lots of $450 \mathrm{~m}^{2}$ and $150 \mathrm{~m}^{2}$ per female, (T1, 22 sows/ha and T2, 66 sows/ha, respectively). An area for cattle raising, under traditional management was used as control (T3). The trial last from May 2011 to April 2013. Changes in the physicochemical and biological conditions of the soils and changes in the floristic composition of the lots were monitored before, during and after the occupation (repeated sampling at intervals 6 months in each of the lots). Organic matter, carbon content, $\mathrm{pH}$, nitrogen, phosphorus, aluminum, cation exchange capacity, compaction and biomass production were evaluated. These variables were evaluated for normal distribution, Levene tests for homogeneity of variances and t-Student test for independent variables. The sows were fed with resources of high local availability, with crude palm oil being the energy base and soy cake the protein base, according to Ocampo (2002). The lots were handled alternately with 30 days of occupation and 30 days of rest. RESULTS The treatment applied indicated highly significant differences $(P<0.005)$ in the percentages of organic matter (MO), nitrogen content $(\mathrm{N})$ and soil carbon $(\mathrm{C})$. Treatment 1 (450 m2 / animal) generated greater effects on the percentage of organic matter $(6.91 \pm$ 2.16), nitrogen (138.25 \pm 43.23$)$ and soil carbon (2.45 \pm 1.08$)$, compared with treatments 2 (150 m2 / animal) and 3 (livestock). The lots submitted to treatment 1 , in the variables $\mathrm{MO}, \mathrm{N}, \mathrm{C}, \mathrm{P}$ and biomass production had superior results in the second year of occupation. CONCLUSIONS The occupation of the soil with breeding sows at densities of $450 \mathrm{~m} 2$ / sow generated significant contributions of nutrients, especially nitrogen ( $160 \mathrm{Kg} / \mathrm{ha}$ ); condition that could be used for the production of fodder for feeding pigs, other animal species or agricultural crops.

Keyword: Field sows, pig farming, soil. 


\section{Evaluación de la calidad nutricional del ensilaje de forraje de quinoa (Chenopodium quinoa willd) con inoculación de microorganismos eficientes em®}

\section{Evaluation of the nutritional quality of quinoa forage silage (Chenopodium quinoa willd) with inoculation of em ${ }^{\circledR}$ efficient microorganisms}

Rodríguez Molano Carlos Eduardo 1, Pulido Suárez Néstor Julián 2, Flórez Gómez Lina María ${ }^{3}$, Niño Monroy Laura Estefanía ${ }^{4}$

${ }^{1}$ Zootecnista Esp. MSc, Docente de la Universidad Pedagógica y Tecnológica de Colombia, Grupo de investigación de Bioquímica y Nutrición Animal (GIBNA). ${ }^{2}$ Médico Veterinario Zootecnista, Msc. Universidad Pedagógica y Tecnológica de Colombia, Grupo de investigación de Bioquímica y Nutrición Animal (GIBNA). ${ }^{3}$ Médico Veterinario Zootecnista, Esp. Msc. Universidad Pedagógica y Tecnológica de Colombia, Grupo de investigación de Bioquímica y Nutrición Animal (GIBNA).

${ }^{4}$ Médico Veterinario Zootecnista, Universidad Pedagógica y Tecnológica de Colombia, Grupo de investigación de Bioquímica y Nutrición Animal (GIBNA). carlos.rodriguez@uptc.edu.co

nestor.pulido@uptc.edu.co

bionutria@gmail.com

estefaniamonroy1994@gmail.com

\section{RESUMEN}

INTRODUCCIÓN. El cultivo de leguminosas, gramíneas y seudo-cereales que aportan los requerimientos nutricionales de los animales son una alternativa para disminuir los costos de producción en los periodos prolongados de sequía. La quinua es un cultivo caracterizado por poseer cualidades nutricionales para el consumo humano y de animales como aves, cerdos y rumiantes, por ser una buena fuente de aminoácidos esenciales, lisina y azufrados, y poseer un alto contenido de vitamina E, B2, B6, ácido fólico y minerales como calcio, zinc, potasio, fosforo y hierro. OBJETIVO. Caracterizar la calidad nutricional del ensilaje de forraje de quinua (Chenopodium quinoa willd) variedad amarilla de maranganí con adición de microorganismos eficientes. MATERIALES Y MÉTODOS. EI proyecto se realizó en el municipio de Nuevo Colón, Boyacá, se seleccionó la 
planta completa de quinoa variedad amarilla de Maranganí (Chenonopodium quinoa $w$ ) recogida a los 60,90 y 120 días después del rebrote de la quinoa, el forraje fue sometido a un proceso de pre marchitamiento bajo condiciones ambientales por 1 hora y picado a un tamaño entre 2 y $2,5 \mathrm{~cm}$ para la elaboración de los microsilios de $1 \mathrm{~kg}$. El material muestreado se analizó en periodos de fermentación de 7, 14, 21 y 30 días con inóculos de microorganismos eficientes $(E M \circledast)$ preparados a razón de 2 Litros activados por tonelada, adicionando aproximadamente $2 \mathrm{~mL}$ por microsilio, se realizaron tres repeticiones para cada tratamiento. Las muestras recolectadas antes y después del proceso fermentativo se les determino la composición química en el Laboratorio de Nutrición animal de la Universidad Pedagógica y Tecnológica de Colombia: Materia seca (MS), humedad $(H)$, proteína cruda $(P C)$, Cenizas $(C Z)$, fibra detergente neutra $(F D N)$ y $\mathrm{pH}$ de las muestras obtenidas después del proceso fermentativo. Se empleó un diseño de parcelas divididas en el tiempo, la distribución de los tratamientos en campo se realizó bajo un diseño completamente al azar y las sub-parcelas fueron las edades del proceso del ensilado con adición de microorganismos eficientes $(E M \circledast)$. Todas las variables fueron sometidas a análisis de varianza, prueba de Tukey $(P<0,05)$. RESULTADOS. Se observaron diferencias estadísticamente significativas $(P<0,05)$ entre las diferentes edades del follaje de quinua para los valores de $\mathrm{PC}, \mathrm{CZ}$ y FDN entre edades de fermentación, evidenciándose que el mayor contenido de proteína cruda se obtuvo a los 60 días de edad de la planta y el mayor porcentaje de CZ se obtuvo a los 21 días de fermentación del ensilaje. En relación con el pH se observó un aumento de forma gradual para cada tratamiento y en cada periodo de muestreo, presentándose diferencias estadísticas significativas. CONCLUSIONES. Los valores bromatológicos de la planta completa y a sus diferentes edades de rebrote y micro silos con adición de microorganismos eficientes en la mayoría de sus principales componentes incrementaron su valor nutricional. Por tal motivo el uso de la quinua como materia prima para la elaboración de ensilajes permitiría el uso multipropósito del cultivo de la quinua, generando grano para el consumo humano y follaje para el consumo animal. 
Palabra clave: Microorganismos eficientes, ensilaje, composición química.

\begin{abstract}
INTRODUCTION. The cultivation of legumes, grasses and pseudo-cereals that provide the nutritional requirements of animals are an alternative to reduce production costs in prolonged periods of drought. Quinoa is a crop characterized by having nutritional qualities for human consumption and animals such as birds, pigs and ruminants, for being a good source of essential amino acids, lysine and sulfur, and having a high content of vitamin E, B2, B6, folic acid and minerals such as calcium, zinc, potassium, phosphorus and iron. OBJECTIVE. Characterize the nutritional quality of the quinoa silage (Chenopodium quinoa willd) yellow variety of Marangani with the addition of efficient microorganisms. MATERIALS AND METHODS. The project was carried out in the municipality of Nuevo Colón, Boyacá, the complete yellow variety quinoa plant of Maranganí (Chenonopodium quinoa $w$ ) was collected at 60,90 and 120 days after the quinoa regrowth, the forage was subjected to a process of pre-wilting under environmental conditions for 1 hour and chopped to a size between 2 and $2.5 \mathrm{~cm}$ for the preparation of $1 \mathrm{~kg}$ microsilts. The sampled material was analyzed in fermentation periods of 7, 14, 21 and 30 days with efficient microorganism inoculums $(E M ®)$ prepared at the rate of 2 Liters activated per ton, adding approximately $2 \mathrm{~mL}$ per microsilium, three repetitions were performed for each treatment. The samples collected before and after the fermentation process were determined the chemical composition in the Animal Nutrition Laboratory of the Pedagogical and Technological University of Colombia: Dry matter (MS), moisture $(H)$, crude protein $(P C)$, Ashes $(C Z)$, neutral detergent fiber (NDF) and $\mathrm{pH}$ of the samples obtained after the fermentation process. A time-divided plot design was used, the distribution of the field treatments was carried out under a completely randomized design and the subplots were the ages of the silage process with the addition of efficient microorganisms $(E M \AA)$. All variables were subjected to analysis of variance, Tukey test $(P<0.05)$. RESULTS. Statistically significant differences $(P<0.05)$ were
\end{abstract}


observed between the different ages of quinoa foliage for PC, CZ and NDF values between fermentation ages, evidencing that the highest crude protein content was obtained at 60 days of age of the plant and the highest percentage of $C Z$ was obtained after 21 days of silage fermentation. In relation to $\mathrm{pH}$, an increase is observed gradually for each treatment and in each sampling period, presenting significant statistical differences. CONCLUSIONS. The bromatological values of the whole plant and at its different ages of regrowth and microsyls with the addition of efficient microorganisms in most of its main components increased its nutritional value. For this reason, the use of quinoa as a raw material for silage production would allow the multi-purpose use of quinoa cultivation, generating grain for human consumption and foliage for animal consumption.

Key words: Efficient microorganisms, silage, chemical composition. 


\title{
Producción de pollos de engorde utilizando Cayeno (Hibiscus rosa-sinensis) $y$ probiótico
}

Broiler production using Cayenne (Hibiscus rosa-sinensis) and probiotic.

\author{
Mariño Guerrero Iván Estebán ${ }^{1}$ \& Roa Vega Maria Ligia ${ }^{2}$ \\ ${ }^{1}$ Estudiante de Medicina Veterinaria y Zootecnia Universidad de los Llanos, \\ 'Zootecnista Esp. MSc, Docente de la Universidad de los Llanos, Grupo de \\ Investigación de Agroforesteria. \\ ivan.marino@unillanos.edu.co \\ ligiaroa2607@gmail.com
}

\section{RESUMEN}

INTRODUCCIÓN. El crecimiento de la producción de aves ha sido determinante en la economía, siendo uno de los sectores para impulsar el desarrollo económico del campo colombiano. El uso de probióticos que contienen bacterias productoras de ácido láctico en la alimentación de las aves, contribuye a la integridad y estabilidad de la flora intestinal, dificultando proliferación de patógenos, lo cual ayuda a prevenir enfermedades y mejorar el rendimiento productivo. OBJETIVO. Evaluar digestibilidad de nutrientes y parámetros productivos en pollos de engorde incluyendo harina Cayeno (Hibiscus rosa sinensis, L) sin y con probiótico (Lactobacilius acidophilus) más pectina como reemplazo del concentrado. MATERIALES Y MÉTODOS. Este proyecto se realizó en Villavicencio, Meta, se utilizaron 90 pollos de engorde, durante 15 días se alimentaron con concentrado de iniciación. Los tratamientos fueron: T1 concentrado comercial molido (CC), T2 CC y $6 \%$ de harina de Cayeno (HC) y T3 CC y $12 \%$ de HC, comparando estos tratamientos sin (SP) y con probiótico más pectina (CP). Para la elaboración de HC se cosecharon tallos verdes y hojas de Cayeno con 60 días después de realizado el último corte, se deshidrataron durante 72 horas a 60 grados centígrados y se molieron. El peso promedio de los pollos fue de $675,1 \pm 50 \mathrm{~g} \mathrm{~g}$, siendo distribuidos en un diseño en bloques completamente al azar y se aplicó la 
prueba de comparación múltiple de Tukey. Para estimar los coeficientes de digestibilidad (COD) se colectaron excretas durante cinco días. A las dietas y excretas se les analizó: materia seca (MS), proteína, fibra, grasa, extracto no nitrogenado $(E N N)$ y fibra detergente neutro (FDN). Se estimaron \% nutrientes digestibles totales (NDT), valor biológico (VB) de la proteína. También se evaluaron variables productivas como: consumo de alimento, aumento de peso, conversión alimenticia y rendimiento en canal. RESULTADOS. EI COD de MS más alto $(P<0,05)$ fue para T2 SP y CP: 0,91 y 0,93 VS $T 10,71$ y 0,72 , lo mismo sucedió con los COD de proteína y fibra de T2 siendo mayores $(P<0,05)$ con realción a T3: 0,88 y 0,92 VS 0,72 y 0,$81 ; 0,82$ y 084 VS 0,56 y 0,57 , respectivamente. El mayor valor de NDT fue para T2: $92,83 \%$ VS T3: $77.56 \%$. El consumo de materia seca fue similar para todos los tratamientos. El aumento de peso diario fue superior $(\mathrm{P}<0,05)$ en $\mathrm{T} 1 \mathrm{CP}$ y SP 93,74 y 89, $78 \mathrm{gr}$ comparándolo con T3 84,08 y $81,95 \mathrm{gr}$, no se observaron diferencias con T2. Las menores conversiones de alimento a peso fueron para T2 SP $(2,0)$ y T3 CP $(1,95)$, observándose un efecto del probiótico porque T2 CP $(1,74)$ fue similar a T1 SP y CP $(1,81$ y 1,86$)$. El rendimiento en canal muestra un comportamiento a favor T1 CP y SP; T2 CP: 66,12, 65,49 y 64,92\%), con relación a los otros tratamientos. CONCLUSIONES. En la mayoría de las variables evaluadas T2 no presentó diferencia con T1, lo cual significa que en las dietas para aves en fase de engorde el concentrado comercial puede ser reemplazado por el $6 \%$ de harina de Cayeno.

Palabra clave: Microorganismos eficientes, digestibilidad, aves, arbustivas

\section{ABSTRACT}

INTRODUCTION. The growth production of broiler chickens has been a determining factor to promote the economic development of the Colombian countryside. It has been a determining factor in the economy, being one of the sectors to promote the economic development of the Colombian countryside. The use of probiotics that contain bacteria producing lactic acid in the diet of the broiler, 
contributes to the integrity and stability of the intestinal flora, making difficult the proliferation of pathogens, which helps to prevent diseases and improve the productive performance. OBJECTIVE. Evaluate nutrient digestibility and productive parameters in broilers including cayenne flour (Hibiscus rosa sinensis, L.) without and with probiotic (Lactobacilius acidophilus) plus pectin as replacement for concentrated food. MATERIALS AND METHODS. This project was carried out in Villavicencio, Meta, 90 broilers were used, for 15 days they were fed with initiation concentrate. The treatments were: T1 concentrated commercial milled (CC), T2 $\mathrm{CC}$ and $6 \%$ of Cayenne flour (CF) and $\mathrm{T} 3 \mathrm{CC}$ and $12 \%$ of $\mathrm{CF}$, comparing these treatments without (WoP) and with probiotic plus pectin (WP). For CF production, green stems and leaves of cayenne were harvested 60 days after the last cut, they were dehydrated for 72 hours at 60 degrees Celsius and then they were ground ground. The average weight of the chickens was $675.1 \pm 50 \mathrm{~g}$, being distributed in a completely randomized block design and Tukey's multiple comparison test was applied. To estimate the digestibility coefficients (COD), excreta were collected during five days. Diets and excreta were analyzed: dry matter (DM), protein, fiber, and fat, non-nitrogenous extract (NNE) and neutral detergent fiber (NDF). Percentage Total digestible nutrients (TND), biological value (BV) of the protein were estimated. Productive variables were also evaluated such as food consumption, weight gain, feed conversion and carcass yield. RESULTS. The highest COD of DM $(P<0,05)$ was for T2 WoP and WP: 0,91 and 0,93 VS T1 0,71 and 0,72 , the same happened with the protein $C O D$ and T2 fiber being greater ( $P$ $<0.05$ ) with relationship at T3: 0,88 and 0,92 vs 0,72 and 0,$81 ; 0,82$ and 0,84 VS 0,56 and 0.57 , respectively. The highest value of TND was for T2: $92,83 \%$ VS T3: $77,56 \%$. DM consumption was similar for all treatments. The daily weight gain was higher $(\mathrm{P}<0,05)$ in T1 WoP and WP 93,74 and 89, $78 \mathrm{~g}$, compared with T3 84,08 and $81,95 \mathrm{~g}$, no differences were observed with T2. The lowest conversions of food to weight were for T2 WoP $(2,0)$ and T3 WP (1.95), observing an effect of the probiotic because T2 WP (1.74) was similar to T1 WoP and WP $(1,81) .1,86)$. The channel yield shows a favorable behavior for T1 WP and WoP; T2 WP: 66, 12, 65, 49 and $64,92 \%$ ), in relation to the other treatments. CONCLUSIONS In most of 
the evaluated variables, T2 did not present a difference with $\mathrm{T} 1$, which means that in the diets for broiler in the fattening phase the commercial concentrate can be replaced by $6 \%$ of cayenne flour.

Key words: Efficient microorganisms, digestibility, broiler, shrubs 


\section{Digestibilidad total de dietas reemplazando el maíz por glicerina cruda en cerdos en crecimiento}

Total digestibility of diets replacing corn with raw glycerin in growing pigs.

Freddy Alexander Toro Baquero1 ; Daniel Alexander Céspedes Sanabria2; María Ligia Roa Vega ${ }^{3}$; Edgar Edilberto Fuentes Reyes ${ }^{4}$

1ZOOTECNISTA, MSc, Docente Departamento de Producción animal, FCARN, Universidad de los Llanos, Villavicencio, Colombia. Semillero de Investigación

METABOLISMO.

${ }^{2} \mathrm{MVZ}$, Esp. cMSc, Docente Departamento de Producción animal, FCARN, Universidad de los Llanos, Villavicencio, Colombia. Semillero de Investigación METABOLISMO.

${ }^{3}$ Zootecnista, MSc, Docente Departamento de Producción animal, FCARN, Universidad de los Llanos, Villavicencio, Colombia. Grupo de Investigación AGROFORESTERIA.

${ }^{4} \mathrm{MVZ}, \mathrm{MSc}, \mathrm{PhD}$, Docente Departamento de Producción animal, FCARN, Universidad de los Llanos, Villavicencio, Colombia. Semillero de Investigación METABOLISMO. efuentes@unillanos.edu.co

\section{RESUMEN}

INTRODUCCION. La glicerina, por sus características energéticas y por su alta palatabilidad, es una materia prima prometedora para sustituir al maíz en dietas para cerdos, además, contribuye en la disminución en costos de alimentación maximizando la utilidad. OBJETIVO. Determinar la digestibilidad total aparente de dietas para cerdos en fase de crecimiento, con diferentes inclusiones de glicerina cruda con el fin de remplazar las fuentes de energía tradicionales, como el maíz.

MATERIALES Y METODOS. El experimento se realizó en la unidad de cerdos de la granja Barcelona y laboratorio de nutrición animal de la Universidad de los Llanos, a $465 \mathrm{msnm}$, temperatura $26^{\circ} \mathrm{C}$, humedad relativa $85 \%$ y precipitación anual $3568 \mathrm{~mm}$. Se utilizaron 25 cerdos mestizos, peso promedio $25 \pm 2.2 \mathrm{~kg}$. Fueron distribuidos en un diseño experimental completamente al azar con cinco tratamientos y cinco repeticiones, cinco cerdos por unidad experimental, alojados individualmente en jaulas metabólicas. Los tratamientos fueron en niveles de 
glicerina de 0, 5, 10, 15 y 20\%, El periodo experimental fue 15 días: doce de adaptación a la jaula metabólica y raciones experimentales, y tres días para la colecta de muestras. Las variables a evaluar fueron coeficiente de digestibilidad: materia seca, proteína, grasa, extracto no nitrogenado, fibra cruda, y \% NDT; y cálculos de: Energía digestible, energía metabolizable, energía neta de mantenimiento y energía neta de producción. Para el análisis de resultados se utilizó el paquete estadístico SPSS v19, se efectuó un análisis de varianza (ANOVA) con su análisis de TUKEY como prueba pos hoc con un nivel de significancia $(P>0,05)$, y análisis de correlación.

RESULTADOS. Energía metabolizable Mcal / $\mathrm{kg}$ de materia seca de la glicerina $3,6 \pm 0,5$. Coeficientes de digestibilidad de la materia seca con diferentes inclusiones de glicerina: T1 (0\%,) 0,87, T2 (5\%) 0,88, T3 (10\%) 0,89, T4 (15\%) 0,89, T5 (20\%) 0,90. Coeficientes de digestibilidad de la proteína con diferentes inclusiones de glicerina: T1 (0\%) 0,91, T2 (5\%) 0,91, T3 (10\%) 0,92, T4 (15\%) 0,83, T5 (20\%) 0,93. Coeficientes de digestibilidad de la fibra cruda con diferentes inclusiones de glicerina: T1 $(0 \%$,$) 0,71, T2 (5\%) 0,72, T3 (10\%) 0,78, T4 (15\%)$ 0,78, T5 (20\%) 0,80. Conversión alimenticia $(\mathrm{kg})$ con diferentes inclusiones de glicerina: T1 (0\%,) 2,94, T2 (5\%) 2,97, T3 (10\%) 2,94, T4 (15\%) 2,94, T5 (20\%) 2,91. Ganancia de peso dia $(\mathrm{kg})$ con diferentes inclusiones de glicerina: T1 $(0 \%$, 0,68, T2 (5\%) 0,67, T3 (10\%) 0,68, T4 (15\%) 0,68, T5 (20\%) 0,68.

CONCLUSIONES. Por los resultados se puede concluir que la inclusión de glicerina de palma africana sustituye parcialmente al maíz, en dietas balanceadas para cerdos en fase de crecimiento se puede llevar hasta el $20 \%$ en la dieta, sin detrimento del aprovechamiento de energía metabolizable y ganancia de peso $(0,68 \mathrm{~kg} / \mathrm{d}$ día) y conversión alimenticia, $\mathrm{kg}(2,9)$.

Palabra clave: cerdos, análisis bromatológico, digestibilidad aparente, glicerina cruda. 


\section{ABSTRACT}

OBJECTIVE. Determine the total apparent digestibility of diets for pigs in the growth phase, with different inclusions of crude glycerin in order to replace traditional energy sources, such as corn. MATERIALS AND METHODS. The experiment was carried out in the pig unit of the Barcelona farm and animal nutrition laboratory of the University of Los Llanos, at 465 meters above sea level, temperature $26 \circ \mathrm{C}$, relative humidity $85 \%$ and annual rainfall $3568 \mathrm{~mm} .25$ mongrel pigs were used, average weight $25 \pm 2.2 \mathrm{~kg}$. They were distributed in a completely randomized experimental design with five treatments and five repetitions, five pigs per experimental unit, housed individually in metabolic cages. The treatments were in glycerin levels of $0,5,10,15$ and $20 \%$. The experimental period was 15 days: twelve of adaptation to the metabolic cage and experimental rations, and three days for the collection of samples. The variables to evaluate were digestibility coefficient: dry matter, protein, fat, non-nitrogen extract, crude fiber, and\% NDT; and calculations of: digestible energy, metabolizable energy, net maintenance energy and net production energy. For the analysis of results, the statistical package SPSS v19 was used, an analysis of variance (ANOVA) was performed with its TUKEY analysis as a post hoc test with a level of significance ( $P>0.05)$, and correlation analysis.RESULTS. Mcal / $\mathrm{kg}$ metabolizable energy of glycerin dry matter $3.6 \pm 0.5$. Digestibility coefficients of dry matter with different glycerin inclusions: T1 (0\%,) 0.87, T2 (5\%) 0.88, T3 (10\%) 0.89, T4 (15\%) 0.89, T5 (20\%) 0.90 . Protein digestibility coefficients with different glycerin inclusions: T1 (0\%) 0.91, T2 (5\%) 0.91 , T3 (10\%) 0.92 , T4 (15\%) 0.83 , T5 ( $20 \%) 0.93$. Digestibility coefficients of crude fiber with different glycerin inclusions: T1 $(0 \%$, 0.71, T2 (5\%) 0.72 , T3 (10\%) 0.78 , T4 (15\%) 0.78 , T5 (20\%) 0.80 . Food conversion $(\mathrm{kg})$ with different glycerin inclusions: T1 $(0 \%)$,2.94 , T2 $(5 \%) 2.97$, T3 (10\%) 2.94, T4 (15\%) 2.94, T5 ( $20 \%)$ 2.91. Day weight gain $(\mathrm{kg})$ with different glycerin inclusions: T1 (0\%,) 0.68, T2 (5\%) 0.67, T3 (10\%) 0.68, T4 (15\%) 0.68, T5 $(20 \%)$ 0.68. CONCLUSIONS. From the results it can be concluded that the inclusion of African palm glycerin partially replaces corn, in balanced diets for growing pigs, up to $20 \%$ can be taken in the diet, without detriment to the use of 
metabolizable energy and weight gain $(0.68 \mathrm{~kg} /$ day) and feed conversion, $\mathrm{kg}$ (2.9).

Key word: Pigs, bromatological analysis, apparent digestibility, crude glycerin 


\title{
Degradabilidad in vitro de ensilajes de Brachiaria decumbes en asociación con otras especies
}

\section{In vitro degradability of Brachiaria decumbes silages in association with other species}

\author{
Edwin Jeovanny Murcia Rodriguez ${ }^{1}$ Mónica Liseth Silva Quintero² \& Roa Vega \\ Maria Ligia $^{3}$ \\ ${ }^{1}$ Medico Veterinario y Zootecnista Universidad de los Llanos \\ 2 Medico Veterinario y Zootecnista Universidad de los Llanos \\ ${ }^{3}$ Zootecnista Esp. MSc, Docente de la Universidad de los Llanos, Grupo de \\ Investigación de Agroforesteria \\ edwin.murcia@unillanos.edu.co \\ monica.liseth.silva@unillanos.edu.co \\ ligiaroa2607@gmail.com
}

\section{RESUMEN}

INTRODUCCIÓN. La sequía intensa del piedemonte llanero, trae limitantes en la nutrición animal, causando pérdidas económicas a los productores sumado a los incrementos de costos de mantenimiento de los animales; los ensilajes son una forma de preservar alimentos de buena calidad, en donde las especies herbáceas y arbustivas toman fuerza por su rápida implementación y aporte nutricional, ayudando a un mantenimiento de la producción en esta epoca critica, mejorando el rendimiento productivo de los animales. OBJETIVO. valorar la degradabilidad in vitro de ensilajes: Brachiaria decumbes (T1), y sus mezclas con: botón de oro (Tithonia diversifolia) (T2), veranera (Cratylia argentea) (T3) matarratón (Gliricidia sepium) (T4) y bore (Alocasia macrorrhiza) (T5), en una proporción 60:40 (gramínea: arbustiva). MATERIALES Y MÉTODOS. Esta investigación se realizó en el municipio de Villavicencio, en la granja de Universidad de los llanos, sede Barcelona ubicada en el Km 12 vía Puerto López, Se recolectaron hojas, tallos y hojas juntos de algunas especies, de los forrajes en las áreas de la Universidad de los llanos, como la gramínea Brachiaria decumbens, Botón de oro (Tithonia diversifolia), Veranera (Cratylia argéntea) Matarratón (Gliricidia sepium) y Bore 
(Alocasia macrorrhiza), estas estaban en un estado de rebrote de 45 días, previamente podados por igual, para homogenizar las muestras, se picó el material en una pica pasto y una vez realizada la asociación de las especies, se ensilaron durante 30 días hojas y tallos de estas especies, a las muestras se les realizó: análisis nutricional y degradabilidad in vitro de: materia seca (DMS), fibra detergente neutro (DFDN), fibra detergente ácido (DFDA) y proteína total (DPT). La incubación $\left(38^{\circ} \mathrm{C}\right)$ con líquido ruminal, solución tampón (Mc Dougall, 1948) aplicando $\mathrm{CO} 2$ para simular condiciones anaeróbicas del rumen, utilizando dos equipos: ANKOM 200 y DK 20 digester. Los horarios de incubación fueron: 0, 6, 10, 24, 48 y 72 horas y posteriormente se realizó análisis nutricional. Comité de ética CO4-F01-007-2016. RESULTADOS. A las 72 horas la DMS y DPT fueron mayores $(p>0,05)$ para T2: 78,0 y $83,0 \%$ vs T5: 63,3 y $67,6 \%$, siendo superiores la DFDN y DFDA para T4: 59,8 y 59,5\% vs T5: 46,9 y 44,3\%). T2 demostró una alta fermentabilidad de MS y PT incrementándose la disponibilidad de nutrientes. Gonzales et al., 2014, argumentan que el botón de oro (Tithonia diversifolia) presenta una alta fermentabilidad de la materia seca y por tanto una rápida disponibilidad de nutrientes, Por lo cual es común asociarlo con gramíneas, para obtener mejores resultados. CONCLUSIONES. DMS y DPT degradación in vitro de la MS y PT registrada en T2 sugieren que mezclar Brachiaria decumbens con botón de oro 78,0 y $83,0 \%$ en proporción $60: 40$, puede ser viable para periodos críticos.

Palabra clave: Brachiaria decumbes, microsilos, degradabilidad In vitro, herbáceas, arbustivas.

\section{ABSTRACT}

INTRODUCTION. The intense drought of the piedmont piedmont, brings limitations in animal nutrition, causing economic losses to the producers added to the increases in animal maintenance costs; Silages are a way of preserving good quality food, where herbaceous and shrub species take strength due to their rapid implementation and nutritional contribution, helping to maintain production at this critical time, improving the productive performance of animals. OBJECTIVE. 
assess the in vitro degradability of silages: Brachiaria decumbes (T1), and mixtures with: gold button (Tithonia diversifolia) (T2), Veranera (Cratylia argentea) (T3) mataratón (Gliricidia sepium) (T4) and bore (Alocasia macrorrhiza) (T5), in a 60:40 ratio (grass: shrub). MATERIALS AND METHODS. This research was carried out in the municipality of Villavicencio, in the farm of Universidad de los llanos, Barcelona headquarters located at Km 12 via Puerto López, leaves, stems and leaves were collected together of some species, from forages in the areas of the University of the plains, such as the Brachiaria decumbens grass, the Golden Button (Tithonia diversifolia), Veranera (Cratylia argéntea) Matarratón (Gliricidia sepium) and Bore (Alocasia macrorrhiza), these were in a 45-day regrowth state, previously pruned by Likewise, to homogenize the samples, the material was chopped in a grass pit and once the species association was made, leaves and stems of these species were silaged for 30 days, the samples were performed: nutritional analysis and degradability in vitro of: dry matter (DMS), neutral detergent fiber (DFDN), acid detergent fiber (DFDA) and total protein (DPT). Incubation (38 ${ }^{\circ}$ C) with ruminal fluid, buffer solution (Mc Dougall, 1948) applying CO2 to simulate anaerobic rumen conditions, using two devices: ANKOM 200 and DK 20 digester. The incubation schedules were: $0,6,10,24,48$ and 72 hours and subsequently a nutritional analysis was performed. Ethics Committee CO4-F01-007-2016. RESULTS: At 72 hours the DMS and DPT were higher $(p>0.05)$ for T2: 78.0 and 83.0\% vs. T5: 63.3 and 67.6\%, the DFDN and DFDA being higher for T4: 59 , 8 and $59.5 \%$ vs. T5: 46.9 and $44.3 \%$ ). T2 demonstrated a high fermentability of MS and PT increasing nutrient availability. Gonzales et al., 2014, argue that the gold button (Tithonia diversifolia) has a high fermentability of dry matter and therefore a quick availability of nutrients, so it is common to associate it with grasses, to obtain better results. CONCLUSIONS: DMS and DPT degradation in vitro of the MS and PT recorded in T2 suggest that mixing Brachiaria decumbens with gold button 78.0 and $83.0 \%$ in $60: 40$ ratio, may be viable for critical periods.

Keywords: Brachiaria decumbes, microsilos, degradability In vitro, herbaceous, shrubs. 


\section{Química sanguínea en pollos de engorde alimentados con harina de botón de oro (Thitonia diversifolia) en fase de finalización}

\section{Blood chemistry in broilers fed with gold button flour (Thitonia diversifolia) in completion}

Litsy L. Gutiérrez-Castro ${ }^{1}$; Jose R Corredor-Matus ${ }^{2}$; Maria Ligia Roa ${ }^{3}$

${ }^{1}$ MVZ MSc Universidad de los Llanos, Grupo de Investigación de Agroforesteria

${ }^{2}$ MVZ MSc y Z MSc Docente Universidad de los Llanos, Grupo de Investigación de Agroforesteria

${ }^{3}$ Zootecnista, MSc, Docente Universidad de los Llanos, Grupo de Investigación de Agroforesteria litsy.gutierrez@unillanos.edu.co jcorredor@unillanos.edu.co mroa@unillanos.edu.co

\section{RESUMEN}

Introducción: La incorporación de fuentes de proteína de origen vegetal en la formulación de dietas para pollos de engorde, en los últimos años ha surgido como una alternativa nutricional que se establece como una necesidad para el desarrollo sostenible de la industria avícola a mediana y pequeña escala. Existe un amplio rango de especies arbóreas y arbustivas útiles para la alimentación animal, para diferentes propósitos productivos, como el botón de oro (Thitonia diversifolia), utilizado en forma de harina. El efecto de la dieta puede evaluarse a traves de la homeostasis sanguínea que permite conocer el estado fisiológico del animal y comportamiento nutricional. Objetivo: Evaluar el efecto de 3 niveles dietéticos de Harina de Boton de Oro ( $\mathrm{HBO}$ ) 5,10 y $15 \%$, sobre la química sanguínea como expresión fisiológica de la ración suministrada, en pollos de engorde en fase de finalización. Métodos: Un total de 300 pollos de engorde de 21 días de edad, ubicados en galpon de la granja Barcelona de la Universidad de los Llanos en Villavicencio, se distribuyeron en jaulas metabólicas de acuerdo a un diseño experimental completamente al azar en 4 tratamientos: control (T0), con harina de 
botón de oro (5\%, T1); (10\%, T2), (15\%, T3) y 5 repeticiones de 15 aves cada uno. Se evaluaron los parámetros sanguíneos a través de las concentraciones plasmáticas de glucosa $(\mathrm{G})$, colesterol $(\mathrm{C})$, triglicéridos (TGC), proteínas totales (PT), albúmina plasmática (AP), alanina amino transferasa (ALT), ácido úrico (AU), nitrógeno ureico $(B U N)$, globulina $(\mathrm{GLO})$, sodio $(\mathrm{Na})$, potasio $(\mathrm{K})$ y calcio $(\mathrm{Ca})$. Resultados: No se encontraron diferencias significativas entre tratamientos para las siguientes variables, cuyos valores de los controles fueron en promedio así: $G$ : $145.9 \pm 43.4 \mathrm{mg} / \mathrm{dl} ;$ C: $138.7 \pm 18.2 \mathrm{mg} / \mathrm{dl} ;$ ALT : $17.8 \pm 2.9 \mathrm{UI} / \mathrm{L} ;$ AST: $223.3 \pm 45.9$ UI/L; BUN: $3.4 \pm 2.0 \mathrm{mg} / \mathrm{dl} ;$ PT: $3.2 \pm 0.4 \mathrm{~g} / \mathrm{dl} ;$ AP : $1.9 \pm 0.4 \mathrm{~g} / \mathrm{dl} ; \mathrm{GLO}: 1.7 \pm 0.5$ $\mathrm{g} / \mathrm{dl} ; \mathrm{K}^{+}: 4.9 \pm 0.6 \mathrm{mEq} / \mathrm{L}$ y $\mathrm{Ca}^{+2}: 7.8 \pm 0.9 \mathrm{mEq} / \mathrm{L}$. Se encontraron diferencias significativas en los parámetros de TGC (15\% Vs Control): $70.8 \pm 26.0^{\mathrm{b}}$ vs $50.7 \pm$ $9.1^{\mathrm{a}} \mathrm{mg} / \mathrm{dl} ; \mathrm{AU}(15 \%): 2.9 \pm 0.8^{\mathrm{b}}$ vs $2.2 \pm 0.4^{\mathrm{a}} \mathrm{mg} / \mathrm{dl}$ y Na$(10 \%): 143.9 \pm 2.0^{\mathrm{b}}$ vs $141.5 \pm 2.6^{\mathrm{a}} \mathrm{mEq} / \mathrm{L}$. La utilización de HBO en la alimentación de pollos de engorde a niveles de hasta el $15 \%$, no ocasionó modificaciones en el $77 \%$ de las variables estudiadas. Las variaciones en las variables TGC, $\mathrm{AU}$ y $\mathrm{Na}^{+}$pueden atribuirse a los porcentajes más elevados de HBO utilizados. Conclusiones: Este estudio indica la factibilidad de incluir este recurso vegetal como una fuente adecuada de proteína vegetal en raciones balanceadas para pollo de engorde.

Palabras Clave: Bioquimica plasmática; aves de corral; botón de oro; nutrición animal; proteína vegetal.

\section{ABSTRACT}

Introduction: The incorporation of sources of protein of vegetable origin in the formulation of diets for broilers, in recent years has emerged as a nutritional alternative that is established as a necessity for the sustainable development of the poultry industry at medium and small scale. There is a wide range of tree and shrub species useful for animal feed, for different productive purposes, such as the golden button (Thitonia diversifolia), used in the form of flour. The effect of the diet can be evaluated through blood homeostasis that allows to know the physiological 
state of the animal and nutritional behavior. Objective: To evaluate the effect of 3 dietary levels of Golden Button Flour (HBO) 5.10 and 15\%, on blood chemistry as a physiological expression of the ration supplied, in broilers in the final phase. Methods: A total of 300 21-day-old broilers, located in a barn of the Barcelona farm of the University of Los Llanos in Villavicencio, were distributed in metabolic cages according to a completely randomized experimental design in 4 treatments: control (T0), with gold button flour (5\%, T1); (10\%, T2), (15\%, T3) and 5 repetitions of 15 birds each. Blood parameters were evaluated through plasma concentrations of glucose $(G)$, cholesterol $(C)$, triglycerides (TGC), total proteins (PT), plasma albumin (AP), alanine amino transferase (ALT), uric acid (AU), urea nitrogen $(B U N)$, globulin (GLO), sodium (Na), potassium (K) and calcium (Ca). Results: No significant differences were found between treatments for the following variables, whose control values were on average as follows: G: $145.9 \pm 43.4 \mathrm{mg} / \mathrm{dl}$; C: 138.7 $\pm 18.2 \mathrm{mg} / \mathrm{dl}$; ALT: $17.8 \pm 2.9 \mathrm{IU} / \mathrm{L} ;$ AST: $223.3 \pm 45.9 \mathrm{lU} / \mathrm{L} ;$ BUN: $3.4 \pm 2.0 \mathrm{mg} /$ dl; PT: $3.2 \pm 0.4 \mathrm{~g} / \mathrm{dl}$; AP: $1.9 \pm 0.4 \mathrm{~g} / \mathrm{dl} ; \mathrm{GLO}: 1.7 \pm 0.5 \mathrm{~g} / \mathrm{dl} ; \mathrm{K}+: 4.9 \pm 0.6 \mathrm{mEq}$ $/ \mathrm{L}$ and $\mathrm{Ca}+2: 7.8 \pm 0.9 \mathrm{mEq} / \mathrm{L}$. Significant differences were found in the TGC parameters (15\% Vs Control): $70.8 \pm 26.0 \mathrm{~b}$ vs $50.7 \pm 9.1 \mathrm{a} \mathrm{mg} \mathrm{/} \mathrm{dl;} \mathrm{AU}(15 \%): 2.9 \pm$ $0.8 \mathrm{~b}$ vs $2.2 \pm 0.4 \mathrm{a} \mathrm{mg} / \mathrm{dl}$ and $\mathrm{Na}+(10 \%): 143.9 \pm 2.0 \mathrm{~b}$ vs $141.5 \pm 2.6 \mathrm{a} \mathrm{mEq} / \mathrm{L}$. The use of HBO in the feeding of broilers at levels of up to $15 \%$, did not cause changes in $77 \%$ of the variables studied. Variations in the TGC, AU and $\mathrm{Na}+$ variables can be attributed to the highest percentages of HBO used. Conclusions: This study indicates the feasibility of including this vegetable resource as an adequate source of vegetable protein in balanced rations for broilers.

Keywords: Plasma biochemistry; poultry; gold button; animal nutrition; vegetal protein. 


\section{Linfoma multicéntrico con presencia de células multinucleadas en un felino de la ciudad de Villavicencio: Reporte de caso}

Multicentric lymphoma with the presence of multinucleated cells in a feline in the city of Villavicencio: Case report

Torres Hernandez Alexander ${ }^{1}$, Salgado Ruiz Stiven ${ }^{1}$ \& Eslava Mocha Pedro Rene ${ }^{2}$

${ }^{1}$ Estudiante de Medicina Veterinaria y Zootecnia Universidad de los Llanos, ${ }^{2} \mathrm{MV}$; M.Sc. Profesor Asociado, Universidad de los Llanos, IALL, Villavicencio, Meta. brayan.torres@unillanos.edu.co jefersson.salgado@unillanos.edu.co pedro.eslava@unillanos.edu.co

\section{RESUMEN}

Se describe un caso clínico de un felino con linfoma multicéntrico y presencia de células multinucleadas; El paciente de 4 años presentó: vómito con vocalizaciones, linfadenomegalia submandibular, dolor abdominal a la palpación, dificultad respiratoria, se tomó muestra de sangre para cuadro hemático y bioquímica sanguínea, se instauró un protocolo de Dipirona: $20 \mathrm{mg} / \mathrm{kg}$, Tramadol: $2 \mathrm{mg} / \mathrm{kg}$ fluidoterapia: $60 \mathrm{ml} / \mathrm{kg} / \mathrm{día}$, Ranitidina: $2 \mathrm{mg} / \mathrm{kg}$.Y se realizó una ecografía en la cual se evidenció una masa a nivel del intestino delgado. Murió 3 horas después de iniciado el tratamiento. Tratándose de un ejercicio de indagación del aula de Patología Sistémica del programa de MVZ de la Unillanos, en este caso se discuten los hallazgos anatomopatológicos macro y micro, los posibles agentes causales de la presentación de linfomas en felinos, la necesidad de efectuar biopsias confirmatorias y marcadores inmunohistoquímicos, con el propósito de acertar en el pronóstico y establecer las correctas formas de manejo de pacientes con linfoma. 
Palabras claves: Linfoma felino, células multinucleadas, multicéntrico, neoplasias en felinos.

\begin{abstract}
A clinical case of a feline with multicentric lymphoma and presence of multinucleated cells is described; The 4-year-old patient presented: vomiting with vocalizations, submandibular lymphadenomegaly, abdominal pain on palpation, respiratory difficulty, blood samples were taken for blood count and blood biochemistry, a Dipirone protocol was established: 20 mg / kg, Tramadol: 2 mg / kg of fluid therapy: $60 \mathrm{ml} / \mathrm{kg} /$ day, Ranitidine: $2 \mathrm{mg} / \mathrm{kg}$. And an ultrasound was performed that showed a mass at the level of the small intestine. He died 3 hours after starting treatment. In the case of a research exercise in the systemic pathology classroom of the Unillanos MVZ program, in this case the macro and micropathological findings, the possible causative agents of the presentation of lymphomas in felines, the need for confirmatory biopsies and immunohistochemical markers, with in order to correct the prognosis and establish the correct ways to manage patients with lymphoma.
\end{abstract}

Keywords: feline lymphoma, multinucleated cells, multicentric feline neoplasms. 


\title{
Descripción Histológica del Sistema Reproductor de la Hembra de Chucha Común (Didelphis marsupialis)
}

\section{Histological Description of the Reproductive System of the Common Chucha Female (Didelphis marsupialis)}

\begin{abstract}
Javier G Cadena B ${ }^{1}$, MVZ; Gustavo G González P², MV, Esp; Maritza Medina R², MVZ, Esp; Nury Trujillo $C^{4}$, Lic. Bio, MV, Esp, MSc.

Escuela de Ciencias Animales; Programa de Medicina Veterinaria y Zootecnia, Facultad de Ciencias Agropecuarias y Recursos Naturales, Universidad de los Llanos, Villavicencio, Colombia). javier.cadena@unillanos.edu.co
\end{abstract}

\section{RESUMEN}

INTRODUCCIÓN La Didelphis marsupialis, es conocida como chucha común o fara, es un mamífero del orden Didelphimorphia que comprende la mayoría de los marsupiales americanos, estos animales son considerados fundamentales en la dinámica de ecosistemas por su papel como controlador de poblaciónes de roedores e insectos, en cuanto a sus características poblacionales pueden ser reservorio de patógenos zoonóticos lo que implica su participación como factor epidemiológico clave en el ciclo de transmisión de la enfermedad de Chagas y la Leishmaniasis. Actualmente, la información disponible sobre esta especie es escasa, especialmente en áreas como la morfología microscópica del sistema reproductivo. OBJETIVO aportar información científica básica de la histología del sistema reproductor de la hembra de la chucha común (D. marsupialis), que servirá como base para futuros estudios en otras áreas como reproducción, patología y la medicina interna de este marsupial. MATERIALES Y MÉTODOS EI estudio se llevó a cabo en la Universidad de los Llanos, ubicada en el kilómetro 12 vía a Puerto López, en el Departamento del Meta (Colombia), en el Laboratorio de Histopatología de la Escuela de Ciencias Animales de la Facultad de Ciencias Agropecuarias y Recursos Naturales. Se utilizaron tejidos previamente fijados en 
formalina bufferada al $10 \%$ de un ejemplar adulto, hembra de la especie Didelphis marsupialis que fueron procesadas en el Laboratorio de Histopatología Veterinaria de la Universidad de los Llanos por los métodos de rutina para tinción de hematoxilina y eosina, como se reportó por Carvajal en 1970. RESULTADOS EI ovario de la chucha común ( $D$. marsupialis) presenta forma ovoide, con una corteza y médula, en la superficie externa está recubierto por un epitelio simple plano; la médula contiene numerosos vasos sanguíneos y linfáticos con tejido conectivo laxo y algunas fibras de músculo liso. La mucosa de cérvix está formada por múltiples pliegues de diferente tamaño, tapizado por un epitelio psuedoestratificado cilíndrico con presencia de cilias y vacuolas. La mucosa de la vagina de la $D$. marsupialis forma pliegues grandes tapizados por un epitelio escamoso estratificado queratinizado, seguida por la túnica muscular y la adventicia. El seno urogenital de la chucha común consta de mucosa, submucosa y túnica muscular. La cloaca de la $D$. marsupialis está recubierta por un epitelio escamoso estratificado queratinizado, la dermis superficial contiene anexos como folículos pilosos y las glándulas sebáceas, de estas últimas es importante recalcar que se distribuye incluso desde la dermis profunda. CONCLUSIONES. El ovario de la D. Marsupialis presento la misma organización y estructura descrita en mamiferos y otros marsupiales. Histologicamente el oviducto presento estructura y caracteristicas similares como son pliegues en la mucosa, tunica muscular y serosa descritos en roedores y otros mamiferos. En el utero a diferencia de otras especies los pliegues de la mucosa son de mayor tamaño y más evidentes, las otras estructuras histologicas son similares al compararlas con otros mamiferos domesticos. En los genitales externos de la chucha comun la caracteristica mas relevante fue la ubicación mas profunda de las glandulas sudoriparas en la dermis al compararla con otras especies de didelphidos.

Palabras clave: marsupial, histología, reproductivo. 


\section{ABSTRACT}

INTRODUCTION Didelphis marsupialis, known as common chucha or fara, is a mammal of the order Didelphimorphia comprising most American marsupials, these animals are considered fundamental in the dynamics of ecosystems for their role as controlling populations of rodents and insects, in terms of their population characteristics can be reservoir of zoonotic pathogens implying their participation as an epidemiological factor key to the cycle of transmission of Chagas disease and Leishmaniasis. Currently, the information available on this species is scarce, especially in areas such as the microscopic morphology of the reproductive system. OBJECTIVE to provide basic scientific information on the histology of the reproductive system of the female of the common chucha (D. marsupialis), which will serve as the basis for future studies in other areas such as reproduction, pathology and internal medicine of this marsupial. MATERIALS AND METHODS The study was carried out at the University of the Llanos, located at kilometer 12 via Puerto López, in the Department of Meta (Colombia), in the Laboratory of Histopathology of the School of Animal Sciences of the Faculty of Sciences Agriculture and Natural Resources. Previously fixed tissues in formlin buffered to $10 \%$ of an adult specimen, female of the species Didelphis marsupialis that were processed in the Histopathology Laboratory Veterinary histopathology of the University of the Plains by routine methods for tintion of hematoxylin and eosin, as reported by Carvajal in 1970. RESULTS The ovary of the common chucha (D. marsupialis) has an ovoid shape, with a cortex and marrow, on the outer surface is coated by a simple flat epithelium; the marrow contains numerous blood and lymph vessels with lax connective tissue and some smooth muscle fibers. The mucosa of cervix is formed by multiple folds of different size, covered by a cylindrical psuedoesttified epithelium with presence of cilia and vacuolas. The mucosa of the vagina of $D$. marsupialis forms large folds upholstered by a keratinized stratified stratified epithelium, followed by the muscular tunic and adventity. The urogenital sinus of the common sucker consists of mucosa, submucosa and muscular tunic. The sewer of $D$. marsupialis is coated by a keratinized stratified squamosque epithelium, the surface dermis contains annexes as hair follicles and the 
sebaceous glands, of the latter it is important to emphasize that it is distributed even from the dermis deep. CONCLUSIONS The ovary of D. Marsupialis presented the same organization and structure described in mammals and other marsupials. Historically the oviduct presented similar structure and characteristics such as folds in the mucosa, muscular tunica and weed described in rodents and other mammals. In the utero unlike other species the mucous membrane folds are larger and more evident, the other histological structures are similar when compared to other domestic mammals. In the external genitalia of the chucha the most relevant feature was the deeper location of the sweat glands in the dermis when compared to other species of didelphidos.

Key words: marsupial, histology, reproductive. 


\title{
Efecto de los probioticos en la produccion de moco y area de la cripta intestinal en pollos de engorde
}

\section{Effect of probiotics on the production of mucus and intestinal crypt area in broilers}

\begin{abstract}
Julieta Esperanza Ochoa Amaya ${ }^{1}$, José Ricardo Corredor Matus², María Ligia Roa Vega ${ }^{31} \mathrm{MVZ}$, MSC, PhD, Docente Universidad de los Llanos, Grupo de Investigación GRIPADS

${ }^{2}$ MVZ, MSc, Docente Universidad de los Llanos, Grupo de Investigación GRIPADS

${ }^{3}$ Zootecnista, MSc, Docente Universidad de los Llanos, Grupo de investigación

AGROFORESTERIA

jcorredor@unillanos.edu.co
\end{abstract}

\section{RESUMEN}

Introducción: Existe una clara necesidad de alternativas seguras parapromotores de crecimiento en la industria avícola diferentes a los antibióticos. Una de estas alternativas eficaces en la producción animal son los probióticos. Tienen el potencial de reducir las enfermedades entéricas, mejorar el desempeño de pollos y disminuir la contaminación de productos avícolas. También permiten establecer y controlar la microflora benéfica y disminuir paulatinamente la patógena. Objetivo: Evaluar el efecto de los probioticos sobre la densidad de la capa de mucina intestinal mediante marcación de las células caliciformes, utilizando tinción de ácido peryódico de Shiff (PAS) y sobre el área de las criptas en pollos de engorde suplementados con probióticos. Metodos: Se obtuvieron muestras intestinales de pollos de engorde que fueron suplementados con los probióticos Saccharomyces cerevisiae (SC); Lactobacillus acidophilus (LA), Bacillus subtilis $(B S)$ y mezcla de $S C+L A+B S$. Las muestras intestinales fueron procesadas por los métodos de rutina para microscopia de luz y secciones histológicas (3-4 $\mu \mathrm{m}$ de grosor) fueron utilizadas para evaluar la densidad de la capa de mucina intestinal mediante marcación de las células caliciformes, utilizando tinción de PAS para detectar la producción de moco. La medición del área de la cripta se determinó 
con el cálculo del diámetro transverso y longitudinal de la cripta. Se realizaron pruebas paramétricas y no paramétricas de "t" para muestras no pareadas. Resultados: Los grupos probióticos presentaron una mayor producción de moco en duodeno $(p=0,0480)(14,48 \pm 1,642) \%$ vs control $(8,674 \pm 0,9708) \%$, en yeyuno $(p=0,0480)(18,02 \pm 1,482) \%$ vs control $(11,50 \pm 1,681) \%$ y una mayor área de la cripta en duodeno $(p=0,0189)(3239 \pm 209,9) \mu m 2$ vs control $(2140 \pm$ $340,2) \mu \mathrm{m} 2$; y en yeyuno $(p=0,0068)(3738 \pm 350,5) \mu \mathrm{m} 2$ vs control $(2243 \pm 202,4)$ $\mu \mathrm{m} 2$. No se encontraron diferencias estadísticas en el íleon con relación a la producción de moco y al área de la cripta. El tratamiento con los probióticos aumentó la producción de moco y el área de la cripta de las vellosidades intestinales del duodeno y yeyuno. No se generaron efectos en estas variables en el íleon. La mayor área intestinal y actividad de las criptas duodenales y del yeyuno con el uso de los probióticos aseguraría a la vez una mayor acción enzimática y área de absorción de nutrientes, lo que deberá reflejarse en un mayor rendimiento en canal. Conclusiones: El uso de probióticos como suplemento en la dieta de pollos de engorde, generó modificaciones en la producción de moco y el área de la cripta intestinal, lo que favorece el proceso digestivo en pollos de engorde.

Palabras clave: Caliciformes, mucina, duodeno, yeyuno, Saccharomyces cerevisiae, Lactobacillus acidophilus

\section{ABSTRACT}

Introduction: There is a clear need for safe alternatives for growth promoters in the poultry industry other than antibiotics. One of these effective alternatives in animal production are probiotics. They have the potential to reduce enteric diseases, improve chicken performance and decrease contamination of poultry products. They also allow to establish and control the beneficial microflora and gradually reduce the pathogen. Objective: To evaluate the effect of probiotics on the density of the intestinal mucin layer by marking the goblet cells, using Shiff's periodic acid staining (PAS) and on the area of the crypts in broilers supplemented 
with probiotics. Methods: Intestinal samples were obtained from broilers that were supplemented with the Saccharomyces cerevisiae (SC) probiotics; Lactobacillus acidophilus (LA), Bacillus subtilis (BS) and mixture of SC + LA + BS. Intestinal samples were processed by routine methods for light microscopy and histological sections (3-4 $\mu \mathrm{m}$ thick) were used to assess the density of the intestinal mucin layer by marking goblet cells, using PAS staining to detect Mucus production. The measurement of the area of the crypt was determined by calculating the transverse and longitudinal diameter of the crypt. Parametric and non-parametric "t" tests were performed for unpaired samples. Results: The probiotic groups had a greater production of mucus in the duodenum $(p=0.0480)(14.48 \pm 1.642) \%$ vs. control $(8.674 \pm 0.9708) \%$, in jejunum $(p=0.0480)(18,02 \pm 1,482) \%$ vs. control $(11.50 \pm$ $1,681) \%$ and a larger area of the crypt in the duodenum $(p=0.0189)(3239 \pm$ 209.9) $\mu \mathrm{m} 2$ vs control $(2140 \pm 340.2) \mu \mathrm{m} 2$; and in jejunum $(p=0.0068)(3738 \pm$ $350.5) \mu \mathrm{m} 2$ vs control $(2243 \pm 202.4) \mu \mathrm{m} 2$. No statistical differences were found in the ileum in relation to mucus production and the area of the crypt. Treatment with probiotics increased mucus production and the crypt area of the intestinal villi of the duodenum and jejunum. No effects were generated on these variables in the ileum. The greater intestinal area and activity of the duodenal and jejunal crypts with the use of probiotics would ensure both greater enzymatic action and nutrient absorption area, which should be reflected in a greater carcass yield. Conclusions: The use of probiotics as a supplement in the diet of broilers, generated changes in the production of mucus and the area of the intestinal crypt, which favors the digestive process in broilers.

Keywords: Goblet, mucin, duodenum, jejunum, Saccharomyces cerevisiae, Lactobacillus acidoph 


\title{
Estudio serológico de Neospora caninum en perros del área urbana y rural del municipio de cumaral, meta.
}

\section{Serological study of Neospora caninum in dogs from the urban and rural area of the municipality of Cumaral, meta.}

\begin{abstract}
Paula Sofía Méndez Ramírez ${ }^{1}$ \& Julián Alberto Marín Henao² ${ }^{1}$ Médico Veterinario y Zootecnista de la Universidad de los Llanos. ${ }^{2}$ Médico Veterinario y Zootecnista de la Universidad de los Llanos. paula.mendez.ramirez@unillanos.edu.co julian.marin@unillanos.edu.co
\end{abstract}

\section{RESUMEN}

Actualmente la neosporosis es una enfermedad de gran importancia en el contexto mundial de la Medicina Veterinaria. Es responsable de grandes pérdidas económicas en las ganaderías debido a las patologías reproductivas que ocasiona, y puede llegar a ser mortal en perros principalmente jóvenes. En Colombia se han realizado pocos estudios especialmente de tipo serológico en caninos. Por lo anterior el presente estudio tuvo como objetivo obtener evidencia serológica de la prevalencia de Neospora caninum en caninos del área urbana y rural del municipio de Cumaral, en el departamento del Meta, donde las condiciones climáticas como temperatura y alta humedad, genera un medio ambiente propicio para incrementar el riesgo de infección a Neospora caninum. Con tal propósito, se colectaron de manera sectorizada y aleatoria $(n=222)$ sueros caninos de diferente edad, sexo, raza y estado reproductivo, se analizaron mediante la técnica de Inmunofluorescencia Indirecta, considerada la técnica de referencia para la detección de Neospora caninum (Palavicini; 2007). Junto al muestreo se realizó una encuesta epidemiológica para determinar los factores de riesgo (raza edad, sexo, manejo, estado general de salud, etc.). La relación entre la seroprevalencia y las variables evaluadas se determinó mediante una prueba de chi cuadrado. El 36,9\% (82/222) presentó anticuerpos contra el parásito. En la 
zona urbana el 38,4\% (43/112) y en la zona rural $25,5 \%$ (39/110). La prueba de chi cuadrado no demostró estadística significativa para ningún factor evaluado ( $p>$ $0,05)$. Con los resultados obtenidos se concluye la presencia del parásito Neospora caninum en el municipio de Cumaral, y se sugiere una transmisión del parásito entre el perro y el ganado de acuerdo con una mayor exposición a las fuentes ambientales de infección.

Palabras claves: Neospora caninum, Inmunofluorescencia indirecta, caninos, situación epidemiológica.

\section{ABSTRACT}

Currently, neosporosis is a disease of great importance in the global context of Veterinary Medicine. It is responsible for large economic losses in livestock because the reproductive pathologies that it produces in the other hand it can be fatal in mainly young dogs. In Colombia, few serological studies have been carried out in canines. Therefore, the goal to the present study aimed to obtain serological evidence of the prevalence of Neospora caninum in canines from the urban and rural areas of the municipality of Cumaral, in the department of Meta, where climatic conditions such as temperature and high humidity generate an environment that to increase the risk of infection to Neospora caninum. For this purpose, they were collected in a sectorized and random sanpling $(n=222)$ canine serum of different age, sex, race and reproductive status were analyzed using the Indirect Immunofluorescence technique, considered the reference technique for the detection of Neospora caninum (Palavicini, 2007). Associated with the sampling we carry out an epidemiological survey to determine the risk factor (breed, age, sex, management, general health status, etc.). The relationship between seroprevalence and the evaluated variables are determined by a chi-squared test. The $36.9 \%$ (82/222) presented antibodies against the parasite. In the urban area, $38.4 \%$ (43/112) and in the rural area 25.5\% (39/110). The chi-squared test did not show significant statistics for any factor evaluated $(p>0.05)$. The results obtained conclude the presence of the parasite Neospora caninum in the municipality of 
Cumaral and suggests a transmission of the parasite between the dog and the cattle according to a greater exposure to environmental sources of infection.

Key words: Neospora caninum, indirect immunoflorescence, canines, epidemiological situation. 
Circovirus porcino tipo 2 (PCV 2) y factores de riesgo en granjas de pequeños productores en municipios del Meta, Colombia

\title{
Swine circovirus type 2 (PCV 2) and risk factors in smallholder farms in municipalities of Meta and Casanare, Colombia
}

\begin{abstract}
Sefair Anzola Rozo ${ }^{1}$ Jorge Luis Parra Arango ${ }^{2}$, Agustín Góngora Orjuela ${ }^{3}$ ${ }^{1}$ Magister en Sistemas Sostenibles de Salud-Producción Animal Tropical ${ }^{2} \mathrm{MV}$, MSc, Docente Universidad de los Llanos, Grupo de Investigación en Reproducción y Genética Animal.

${ }^{3} \mathrm{MV}, \mathrm{MSc}$, Dr.Sci Docente Universidad de los Llanos, Grupo de Investigación en Reproducción y Genetica Animal.

sefamvz76@gmail.com

ilparra@unillanos.edu.co

agongora@unillanos.edu.co
\end{abstract}

\section{RESUMEN}

INTRODUCCIÓN. Circovirus porcino-2 (PCV-2) es un virus DNA desnudo, asociado a síndrome de desgaste multisistémico posdesdete, dermatitis, nefropatía, neumonía y desórdenes digestivos y reproductivos e inmunodepresión. OBJETIVO. Identificar mediante pruebas serológicas la presencia de PCV2 e identificar factores de riesgo asociados a la infección en municipios del Meta, Colombia. MATERIALES Y MÉTODOS. Se hizo estudio epidemiológico transversal a PCV-2 en pequeñas piaras del municipio de Acacías y Guamal, departamento del Meta, Colombia, para cuantificar magnitud y distribución. Se seleccionaron 10 piaras por conveniencia, con dos niveles de muestreo en predios, por población y por grupos etarios. Además se analizaron otro grupo de muestras de animales a nivel de frigorífico. Los sueros se congelaron a $-70 \circ \mathrm{C}$, hasta correrles dos pruebas de Elisa de bloqueo, para IgM e IgG a PCV-2. Se levantó una encuesta breve sobre infraestructura, manejo, salud y producción por piara. La seroprevalencia se determinó con los reactores a IgG por encima del 
punto de corte, de acuerdo a instrucciones del fabricante. El contraste entre las densidades ópticas (DO) de lgG e IgM, clasificó los animales con: infección activa, infección reciente, infección antigua y seronegativos. La asociación entre, seroprevalencia con predio, sexo, grupos etáreos y clasificación serológica, se hizo por $\mathrm{X}^{2}$ de independencia. Los factores asociados a la seroprevalencia y de ésta con variables de salud y reproducción, se determinó por razón de prevalencias (RP) e intervalos de confianza de RP (ICRP) mediante el software epidat 3.1. RESULTADOS. La seroprevalencia a IgM e IgG contra PCV-2 fue: 14,8 y $69,6 \%$, siendo significativamente diferentes ( $p<0,01$ ). El sexo no influenció La seroprevalencia, siendo: machos $5,4 \%$ y hembras $25 \%$ ( $p>0,05$ ); el grupo etáreo fue independiente de la seroprevalencia $(p>0,05)$ siendo: Lactantes $61,1 \%$, destetos: 72,7, cerdas en lactancia $85,7 \%$, Cerdas gestantes $72,7 \%$, cerdo(a)s en ceba $70,6 \%$ y reproductores $50 \%$ ( $p>0,05)$. La piara influenció significativamente la respuesta serológica a PCV-2 $(p<0,01)$ con un rango de seropositivos entre $15,4 \%$ y 100\%. La clasificación serológica fue: infección activa 2/135 = 1,5 \%; Infección reciente $18 / 135=13,3 \%$, Infección antigua $75 / 135=55,6$ y seronegativos $40 / 135=$ $29,6 \%$, esta distribución fue independiente del grupo etáreo $(p>0,05)$. La población del predio: ( $\geq 95$ cerdos), la no colecta sistemática de estiércol $(p<0,01)$, la presencia de otras especies pecuarias como: Bovinos y equinos $(p<0,01)$, animales de compañía: felinos $(p<0,01)$ y la aplicación de vacunas contra mycoplasmosis y $E$. coli $(p<0,01)$, fueron factores causales asociados a la seroprevalencia en piaras, así: Población del predio: $R P=1,51 \mathrm{Li}=1,14 \mathrm{Ls}=2,01$; la no colecta sistemática de estiércol: $\mathrm{RP}=1,39 \mathrm{Li}=1,13 \mathrm{Ls}=1,71$; presencia de ganadería bovina: $\mathrm{RP}=1,4 \mathrm{Li}=1,18 \mathrm{Ls}=1,68$; presencia de equinos: $1,4 \mathrm{Li}=1,14$; $L s=1,67$; presencia de gatos domésticos: $R P=3,4 \mathrm{Li}=1,67 ; \mathrm{Ls}=6,81$; aplicación de vacuna contra micoplasma: $\mathrm{RP}=1,4 \mathrm{Li}=1,12 \mathrm{Ls}=1,85$ y la aplicación de vacuna contra $E$. coli: $\mathrm{RP}=1,3 \mathrm{Li}=1,01 \mathrm{Ls}=1,72$. La seropositividad a PCV-2, no se encontró asociada a enflaquecimiento, diarreas, abortos y momias, $(p>0,05)$, pero si a la repetición de servicios, descarte por repetición de servicios y por bajo número de lechones $(p<0,01)$. La seroprevalencia fue factor causal asociado a: Repetición de servicios: $\mathrm{RP}=11,26 \mathrm{Li}=1,58$; $\mathrm{Ls}=80,26$; descarte por repetición 
de servicios: $R P=1,18 \mathrm{Li}=0,99 ; \mathrm{Ls}=1,41$ y descarte por bajo número de lechones: $\mathrm{RP}=4,7 \mathrm{Li}=2,22$; $\mathrm{LS}=9$ 9,94. CONCLUSIONES. PCV-2, es entidad patológica, establecida en piaras de pequeños productores del Piedemonte Llanero con efectos en salud y producción.

Palabra clave: factores de riesgo, Circovirus porcino 2, estudio transversal, epidemiologia.

\section{ABSTRACT}

INTRODUCTION. Porcine-2 circovirus (PCV-2) is a naked DNA virus, associated with post-weaning multisystemic wear syndrome, dermatitis, nephropathy, pneumonia and digestive and reproductive disorders and immunosuppression. OBJECTIVE. Identify the presence of PCV2 through serological tests and identify risk factors associated with infection in municipalities of Meta. MATERIALS AND METHODS. A cross-sectional epidemiological study of PCV-2 was carried out in small piaras in the municipality of Acacías and Guamal, department of Meta, Colombia, to quantify magnitude and distribution. Ten piaras were selected for convenience, with two levels of sampling on land, by population and by age groups. In addition, another group of animal samples was analyzed at the refrigerator level. The sera were frozen at $-70, C$, until they were run two tests of Elisa blocking, for $\operatorname{lgM}$ and $\operatorname{lgG}$ to PCV-2. A brief survey on infrastructure, management, health and production by piara was carried out. Seroprevalence was determined with the $\operatorname{lgG}$ reactors above the cut-off point, according to the manufacturer's instructions. The contrast between the optical densities (OD) of IgG and $\lg \mathrm{M}$, classified the animals with: active infection, recent infection, old infection and seronegative. The association between seroprevalence with land, sex, age groups and serological classification was made by $x^{2}$ of independence. The factors associated with seroprevalence and the latter with health and reproduction variables, were determined by prevalence (RP) and RP confidence intervals (ICRP) using epidat 3.1 software RESULTS. The seroprevalence to $\lg M$ and $\lg G$ 
against PCV-2 was: 14.8 and $69.6 \%$, being significantly different $(p<0.01)$. Sex did not influence seroprevalence, being: males $5.4 \%$ and females $25 \%$ ( $p>0.05)$; the age group was independent of seroprevalence ( $p>0.05$ ) being: Infants $61.1 \%$, weaning: 72.7 , sows in lactation $85.7 \%$, pregnant sows $72.7 \%$, pig (s) in baits $70.6 \%$ and breeders $50 \%$ ( $p>0.05$ ). The piara significantly influenced the serological response to PCV-2 $(p<0.01)$ with a seropositive range between $15.4 \%$ and $100 \%$. The serological classification was: active infection $2 / 135=1.5 \%$; Recent infection 18/135 $=13.3 \%$, Old infection $75 / 135=55.6$ and seronegative $40 / 135=29.6 \%$, this distribution was independent of the age group ( $p>0.05$ ). The population of the farm: ( $\geq 95$ pigs), the systematic non-collection of manure $(p<0.01)$, the presence of other livestock species such as: Bovines and horses $(p<0.01)$, pets: felines $(p<0.01)$ and the application of vaccines against mycoplasmosis and E. coli $(p<0.01)$, were causal factors associated with seroprevalence in herds, as follows: Population of the property: $\mathrm{RP}=1.51 \mathrm{Li}=1$, $14 \mathrm{Ls}=2.01$; non-systematic collection of manure: $\mathrm{RP}=1.39 \mathrm{Li}=1.13 \mathrm{Ls}=1.71$; presence of cattle: $\mathrm{RP}=1.4 \mathrm{Li}=1.18 \mathrm{Ls}=1.68$; presence of horses: $1.4 \mathrm{Li}=1.14$; $\mathrm{LS}=1.67$; presence of domestic cats: $\mathrm{RP}=3.4 \mathrm{Li}=1.67 ; \mathrm{Ls}=6.81 ;$ Mycoplasma vaccine application: $\mathrm{RP}=1.4 \mathrm{Li}=1.12 \mathrm{Ls}=1.85$ and the $\mathrm{E}$. coli vaccine application: $\mathrm{RP}=1.3 \mathrm{Li}=1.01 \mathrm{Ls}=1.72$. The seropositivity to PCV-2 was not found associated with thinning, diarrhea, abortions and mummies, ( $p>0.05)$, but if the repetition of services, discard by repetition of services and by low number of piglets $(p<0.01)$. Seroprevalence was a causal factor associated with: Repetition of services: $\mathrm{RP}=11.26 \mathrm{Li}=1.58$; $\mathrm{Ls}=80.26$; discard by repetition of services: $\mathrm{RP}$ $=1.18 \mathrm{Li}=0.99 ; \mathrm{Ls}=1.41$ and discard by low number of piglets: $\mathrm{RP}=4.7 \mathrm{Li}=$ 2.22; Ls $=9.94$. CONCLUSIONS PCV-2, is a pathological entity, established in piaras of small producers of Piedemonte Llanero with effects on health and production.

Key words: Palabra clave: risk factors, PCV2, cross-sectional study, epidemiology. 


\section{Efectos de la adición de probióticos en la morfología intestinal en pollos de engorde}

\section{Effects of addition of probiotics in intestinal morphology in broilers}

Owens J Barros Barrios ${ }^{1}$, Est Med Vet Zoo; Julieta E Ochoa Amaya ${ }^{1}$, Med Vet Zoot, MsC, PhD; José R Corredor Matus ${ }^{1}$, Med Vet Zoot, MSc; Gustavo González Paya $^{1}$, Med Vet , Esp; Maria L Roa Vega ${ }^{2}$, Zoot, MSc

*Proyecto "Efectos de la adición de probióticos de la morfología intestinal en pollos de engorde" financiado por DGI Universidad de los Llanos. 'Grupo de Investigación en Patología en Animales domésticos y silvestres (GRIPADS), Facultad de Ciencias Agropecuarias y Recursos Naturales, Universidad de los Llanos, Villavicencio, Colombia. ${ }^{2}$ Grupo de investigación en Agroforesteria, Universidad de los Llanos, Villavicencio, Colombia. owens.barros@unillanos.edu.co

\section{RESUMEN}

INTRODUCCIÓN: Existe una clara necesidad de alternativas seguras para promotores de crecimiento en la industria avícola diferentes a los antibióticos. Una de estas alternativas eficaces en la producción animal son los probióticos. Tienen el potencial de reducir las enfermedades entéricas, mejorar el desempeño de pollos y disminuir la contaminación de productos avícolas. OBJETIVOS: Se estudió el efecto de probióticos sobre la morfometria intestinal. Fue cuantificada en porcentaje (\%) la capa de mucina intestinal y las áreas de las criptas en el intestino delgado, en pollos de engorde suplementados con probióticos y sus controles. MATERIALES Y MÉTODOS: Se trabajaron dos grupos experimentales, el Grupo Control (GC) correspondiente al tratamiento 1 (T1) sin probióticos y Grupo Probióticos (GP) que agrupa los tratamientos: T2 con Saccharomyces cerevisiae (SC), T3 con Lactobacillus acidophilus (LA), T4 con Bacillus subtilis (BS) y $\mathrm{T} 5$ con una mezcla de $\mathrm{SC}+\mathrm{LA}+\mathrm{BS}$. Las muestras intestinales fueron procesadas por los métodos de rutina para microscopia de luz y se realizaron secciones histológicas. La longitud de la vellosidad en las diferentes porciones del intestino delgado fue calculada midiendo la distancia entre la punta de la 
vellosidad y su base, excluyendo la cripta. Por cada sección intestinal se realizaron cinco mediciones, se promediaron y el área de la vellosidad se calculó así: Área de vellosidad $=$ (Ancho basal + ancho apical $) \times$ altura de la vellosidad. Para evaluar la capa de mucina intestinal mediante marcación de células caliciformes, fue utilizada tinción de PAS para la producción de moco (\%). La medición del área de la cripta se determinó con el cálculo del diámetro transverso y longitudinal de la cripta. Se realizaron pruebas paramétricas y no paramétricas de "t" para muestras no pareadas. RESULTADOS: los grupos probióticos presentaron una mayor área $(p=0,0127)(368700 \pm 47170) \mu \mathrm{m}^{2}$ vs control $(200300$ $\pm 10910) \mu m^{2}$; ancho basal $\mathrm{p}=0,0049(155,4 \pm 13,90) \mu \mathrm{m}$ vs control $(103,9 \pm$ $8,74) \mu \mathrm{m}$; ancho apical $(p=0,0024)(90,62 \pm 5,205) \mu \mathrm{m}$ vs control $(61,13 \pm 4,490) \mu \mathrm{m}$ en el duodeno. No se encontraron diferencias estadísticas en el yeyuno e íleon. El tratamiento con los probióticos aumentó el área total, ancho basal y apical de la vellosidad intestinal duodenal. Los grupos probióticos presentaron una mayor producción de moco en duodeno $(\mathrm{p}=0,0480)(14,48 \pm 1,642) \%$ vs control $(8,674 \pm$ $0,9708) \%$, en yeyuno $(p=0,0480)(18,02 \pm 1,482) \%$ vs control $(11,50 \pm 1,681) \%$ y una mayor área de la cripta en duodeno $(p=0,0189)(3239 \pm 209,9) \mu m^{2}$ vs control $(2140 \pm 340,2) \mu \mathrm{m}^{2}$; y en yeyuno $(\mathrm{p}=0,0068)(3738 \pm 350,5) \mu \mathrm{m}^{2}$ vs control $(2243 \pm 202,4) \mu m^{2}$. No se encontraron diferencias estadísticas en el íleon con relación a la producción de moco y al área de la cripta. CONCLUSIONES: El uso de probióticos modificó la morfometría intestinal duodenal, en las áreas, anchos basales y apicales. No se generaron efectos en yeyuno e íleon. No hubo cambios en la longitud de las vellosidades de duodeno, yeyuno e íleon con respecto a su control. El tratamiento con los probióticos aumentó la producción de moco y el área de la cripta de las vellosidades intestinales del duodeno y yeyuno.

Palabra clave: Pollos de engorde, probióticos, histomorfología intestinal 


\section{ABSTRACT}

INTRODUCTION: There is a clear need for safe alternatives for growth promoters in the poultry industry other than antibiotics. One of these effective alternatives in animal production are probiotics. They have the potential to reduce enteric diseases, improve chicken performance and decrease contamination of poultry products. OBJECTIVES: The effect of probiotics on intestinal morphometry was studied. The intestinal mucin layer and the crypt areas in the small intestine, in broilers supplemented with probiotics and their controls, were quantified in percentage (\%). MATERIALS AND METHODS: Two experimental groups, the Control Group (GC) corresponding to treatment 1 (T1) without probiotics and Probiotic Group (GP) that groups the treatments: T2 with Saccharomyces cerevisiae (SC), T3 with Lactobacillus acidophilus (LA) ), T4 with Bacillus subtilis (BS) and T5 with a mixture of SC + LA + BS. Intestinal samples were processed by routine light microscopy methods and histological sections were performed. Villus length in different portions of the small intestine was calculated by measuring the distance between the tip of the villus and its base, excluding the crypt. Five measurements were made for each intestinal section, averaged and the villus area was calculated as follows: Villus area $=($ Basal width + apical width $) \times$ Villus height. To evaluate the intestinal mucin layer by labeling goblet cells, PAS staining was used for mucus production (\%). The measurement of the area of the crypt was determined by calculating the transverse and longitudinal diameter of the crypt. Parametric and non-parametric " $t$ " tests were performed for unpaired samples. RESULTS: the probiotic groups presented a greater area $(p=0.0127)(368700 \pm$ 47170) $\mu \mathrm{m} 2$ vs control $(200300 \pm 10910) \mu \mathrm{m} 2$; basal width $\mathrm{p}=0.0049(155.4 \pm$ 13.90) $\mu \mathrm{m}$ vs control $(103.9 \pm 8.74) \mu \mathrm{m}$; apical width $(p=0.0024)(90.62 \pm 5.205)$ $\mu \mathrm{m}$ vs control $(61.13 \pm 4.490) \mu \mathrm{m}$ in the duodenum. No statistical differences were found in the jejunum and ileum. Treatment with probiotics increased the total, basal and apical width of the duodenal intestinal villus. The probiotic groups had a higher production of mucus in the duodenum $(p=0.0480)(14.48 \pm 1.642) \%$ vs. control $(8.674 \pm 0.9708) \%$, in jejunum $(p=0.0480)(18.02 \pm 1,482) \%$ vs control $(11.50 \pm$ $1,681) \%$ and a larger area of the crypt in the duodenum $(p=0.0189)(3239 \pm$ 
209.9) $\mu \mathrm{m} 2$ vs control $(2140 \pm 340.2) \mu \mathrm{m} 2$; and in jejunum $(p=0.0068)(3738 \pm$ $350.5) \mu \mathrm{m} 2$ vs control $(2243 \pm 202.4) \mu \mathrm{m} 2$. No statistical differences were found in the ileum in relation to mucus production and the area of the crypt. CONCLUSIONS: The use of probiotics modified duodenal intestinal morphometry, in the areas, basal and apical widths. No effects on jejunum and ileum were generated. There were no changes in the length of the villi of the duodenum, jejunum and ileum with respect to their control. Treatment with probiotics increased mucus production and the crypt area of the intestinal villi of the duodenum and jejunum.

Key words: Broiler, probiotic, intestinal histomorphology 


\title{
Adenocarcinoma mamario metastásico felino: reporte de caso
}

\section{Feline metastatic mammary adenocarcinoma: case report}

\author{
Sierra Martinez Zully Esmeralda ${ }^{1}$, Velasquez Peña Maria Alejandra ${ }^{1}$ \& Eslava \\ Mocha Pedro Rene ${ }^{2}$ \\ ${ }^{1}$ Estudiante de Medicina Veterinaria y Zootecnia Universidad de los Llanos, \\ ${ }^{2}$ MV; M.Sc. Profesor Asociado, curso de Patología Sistémica, Universidad de los \\ Llanos, IALL, Villavicencio, Meta. \\ zully.sierra@unillanos.edu.co \\ maria.velasquez.pena@unillanos.edu.co \\ pedro.eslava@unillanos.edu.co
}

\section{RESUMEN}

INTRODUCCIÓN La agresividad del tumor es característica en felinos, invade el circuito linfático y metastatiza a distancia con rapidez: la influencia hormonal está involucrada en la patogénesis de los tumores mamarios en gatos por esta razón se ha observado que gatas ovariohisterectomizadas antes de los seis meses de edad muestran efectos protectores evidenciados en una reducción hasta de siete veces el riesgo de desarrollar cáncer mamario, comparado con gatas intactas, se cree que existe una fuerte asociación entre progestágenos o estrógenos sintéticos donde se ha demostrado una posible dependencia de los tumores a hormonas esteroidales en estudios inmunohistoquímicos.(Buracco, 2014; Ortiz, 2013) La positividad a receptores de progesterona sugiere un posible rol de esta hormona en el crecimiento temprano tumoral en gatas, y la inmunomarcación a receptores de estrógeno está relacionada con el fenotipo y el comportamiento agresivo de algunos carcinomas de tipo invasivo (Fidalgo, 2003). DESCRIPCIÓN DEL CASO Se reporta el caso de un felino, raza mestizo, sexo hembra, edad diez años, atendido en una clínica particular como motivo de consulta dehiscencia de puntos debido a mastectomía parcial realizada 15 días antes. A la paciente le había realizado ovariohisterectomía hace un año debido a la presentación de piometra, cabe resaltar que tuvo más de cinco aplicaciones de progestágenos; a los seis 
meses de este procedimiento, presentó pequeñas masas semiduras en las glándulas mamarias izquierdas las cuales se extirparon. Al examen clínico presento anorexia, inapetencia, mucosas pálidas, hipertermia localizada en el abdomen y herida abierta de tres centímetros de ancho por ocho centímetros de largo en el abdomen con cambio de coloración rojo negruzca y restos de fibrina en los bordes de la herida. Luego de hacérsele las pruebas diagnósticas necesarias al siguiente día fallece. A la necropsia se encontró masa en alto relieve de color blanquecino de forma redondeada en el lóbulo caudal izquierdo del pulmón de dos centímetros, en el lóbulo medial derecho del hígado se evidencio una pequeña masa de forma irregular de color blanco amarillento, se observaron masas gelatinosos de fibrina adheridas al bazo, pericardio, cavidad torácica intestino, mesenterio. se recolectó muestra de órganos afectados fijadas en formol bufferado al $10 \%$, procesada para análisis histopatológico, en el laboratorio de patología de la Universidad de los Llanos, mediante la técnica de hematoxilina y eosina de rutina. La histopatología mostró estructuras en forma de túbulos ramificados con epitelio cúbico y células pleomórficas con citoplasma acidófilo intenso. DISCUSIÓN: Por la historia clínica e histopatología se diagnosticó una Adenocarcinoma mamario, con metástasis en pulmones, hígado, bazo, páncreas, riñón y serosas de intestinos; y peritonitis quirúrgica con respuesta inflamatoria plasmocítica severa en los órganos mencionados anteriormente. el uso de progestágenos en gatos aumenta el desarrollo de tumores malignos por ende es un suceso muy común en felinos (Morris y Dobson,2001). CONCLUSIÓN: Por morfología de los focos metastásicos se determina la presentación de un Adenocarcinoma mamario asociado a tratamiento con progestágenos.

Palabra clave: Adenocarcinoma mamario, peritonitis quirugica, felino, prostagenos, metastasis. 


\section{ABSTRACT}

INTRODUCTION The aggressiveness of the tumor is characteristic in felines, it invades the lymphatic circuit and metastasizes at a distance quickly: the hormonal influence is involved in the pathogenesis of mammary tumors in cats for this reason it has been observed that ovariohysterectomized cats before six months of age show protective effects evidenced in a reduction of up to seven times the risk of developing breast cancer, compared to intact cats, it is believed that there is a strong association between progestogens or synthetic estrogens where a possible dependence of tumors to steroidal hormones has been demonstrated in studies immunohistochemicals (Buracco, 2014; Ortiz, 2013) Progesterone receptor positivity suggests a possible role of this hormone in early tumor growth in cats, and immunolabeling to estrogen receptors is related to the phenotype and aggressive behavior of some invasive carcinomas (Fidalgo, 200 3). CASE DESCRIPTION The case of a feline, mestizo race, female sex, age ten years, attended in a particular clinic as a reason for consultation of point dehiscence due to partial mastectomy performed 15 days before is reported. The patient had had an ovariohysterectomy a year ago due to the presentation of pyometra, it should be noted that she had more than five applications of progestogens; Six months after this procedure, he presented small semi-hard masses in the left mammary glands, which were removed. The clinical examination showed anorexia, lack of appetite, pale mucous membranes, hyperthermia located in the abdomen and an open wound three centimeters wide and eight centimeters long in the abdomen with a change of blackish red color and fibrin remains on the edges of the wound. After having the necessary diagnostic tests the next day he dies. At necropsy, a highrelief mass of whitish color was found in a rounded form in the left caudal lobe of the lung of two centimeters, in the right medial lobe of the liver, a small irregular mass of yellowish white color was evident, gelatinous masses were observed of fibrin attached to the spleen, pericardium, thoracic bowel cavity, mesentery. A sample of affected organs fixed in $10 \%$ buffered formalin, processed for histopathological analysis, was collected in the pathology laboratory of the University of Los Llanos, using the routine hematoxylin and eosin technique. 
Histopathology showed structures in the form of branched tubules with cubic epithelium and pleomorphic cells with intense acidophilus cytoplasm.

DISCUSSION: Due to the clinical history and histopathology, a mammary adenocarcinoma was diagnosed, with metastases in the lungs, liver, spleen, pancreas, kidney and serous intestines; and surgical peritonitis with severe plasmocytic inflammatory response in previously treated organs. The use of progestogens in cats increases the development of malignant tumors; therefore it is a very common success in felines (Morris and Dobson, 2001). CONCLUSION:

The presentation of a mammary adenocarcinoma associated with progestogen treatment is determined by morphology of the metastatic foci.

Key words: Mammary adenocarcinoma, surgical peritonitis, feline, progestogens, metastases. 
Identificación de biomarcadores con alta sensibilidad en ambientes acuáticos potencialmente contaminados por hidrocarburos - hallazgos en la inducción de CYP 4501A

\section{Identification of biomarkers with high sensitivity in aquatic environments potentially contaminated by hydrocarbons - findings in the induction of CYP} $450 \mathrm{~A}$

Rodríguez-Jiménez Jessica $Y^{1}$, Corredor-Santamaría Wilson ${ }^{1}$, Mora-Solarte Diego ${ }^{1}$, Calderón-Delgado Ivonne ${ }^{1}$, Navas-Antón José María ${ }^{2}$, VelascoSantamaría Yohana*1

1 Universidad de los Llanos /Grupo de Investigación en Biotecnología y Toxicología Acuática y Ambiental BioTox - FCARN

2 INIA, Instituto Nacional de Investigación y Tecnología Agraria y Alimentaria, Departamento de Medio Ambiente ymvelascos@unillanos.edu.co

\section{RESUMEN}

INTRODUCCIÓN. La contaminación ambiental es claramente un tema que en los últimos años ha tomado importancia en diferentes sectores. Principalmente en el departamento del Meta, la producción de hidrocarburos es una de las actividades que atrae mayor atención, debido a que es considerada como una de las actividades que mayor riesgo ambiental pueden producir y aunque son evidentes algunos impactos ambientales como las emisiones atmosféricas y/o alteración de la calidad del agua, la reglamentación ambiental es laxa en este aspecto. Por tal motivo, la evaluación de respuestas celulares en los organismos que están expuestos en estos ambientes, constituyen una herramienta importante para la evaluación del riesgo. La evaluación de la actividad EROD permite identificar si un organismo ha sido expuesto a compuestos planares como los hidrocarburos y de esta forma evaluar los riesgos asociados a su metabolismo. OBJETIVO. Evaluar la actividad EROD en peces de la cuenca de la Orinoquia en campo, utilizando zonas potencialmente contaminadas y zonas con baja probabilidad de 
contaminación. MATERIALES Y MÉTODOS. En este estudio se realizaron muestreos de campo durante la temporada de verano (aguas bajas) y de invierno (aguas altas). Se colectaron ejemplares de juveniles de cachama blanca (Piaractus brachypomus) en 3 estaciones piscícolas y, en el río Acacias se capturaron ejemplares de luminosa (Aequidens metae) en zonas con potencial contaminación de hidrocarburos. Adicionalmente, fueron capturados ejemplares de luminosa en el caño Cuncia, como organismos ede referencia. De cada especie se tomaron muestras de hígado, se almacenaron en vapores de nitrógeno y se transportaron al laboratorio para su evaluación. La determinación de la actividad enzimática EROD se evaluó a través de fluorescencia expresando los resultados en función de la concentración de proteína. RESULTADOS. Se encontró que la actividad EROD fue más elevada en las zonas donde se tenía sospecha de contaminación. Dos de las tres granjas piscícolas presentaron valores elevados de contaminación en aguas altas, mientras que en aguas bajas solamente una de las dos presentó valores significativamente más elevados. Mientras en el río Acacías, los peces capturados en la zona con mayor potencial de contaminación por hidrocarburos presentaron valores significativamente más altos que los peces capturados en el sitio de referencia, tanto en aguas altas como aguas bajas. CONCLUSIONES. La determinación de la actividad EROD es una herramienta confiable para evidenciar la presencia de compuestos planares como los hidrocarburos y su efecto potencial en zonas donde no se han evidenciado evidentes y cuantificables impactos ambientales.

Palabra clave: Actividad enzimática, EROD, hidrocarburos, Orinoquia, peces.

\section{ABSTRACT}

INTRODUCTION. Environmental pollution is clearly an issue that in recent years has taken importance in different sectors, mainly in the department of Meta, in which the production of hydrocarbons is one of the activities that attracts more attention, because it is considered as one of the activities that greater 
environmental risk can produce and although some environmental impacts are evident as the atmospheric emissions and/or alteration of the quality of the water, the environmental regulation is lax in this aspect. For this reason, the evaluation of cellular responses in the organisms that are exposed in these environments constitute an important tool for risk assessment. The evaluation of the EROD activity allows to identify if an organism has been exposed to planar compounds such as hydrocarbons and in this way to evaluate the risks associated to its metabolism. OBJECTIVE. Evaluate EROD activity in fish from the Orinoquia basin in the field, using potentially contaminated areas and areas with low probability of contamination. MATERIALS AND METHODS. In this study field sampling was carried out during the summer (low water) and rainy seasons (high water). Juveniles of cachama blanca (Piaractus brachypomus) were collected in 3 fish farming stations and, in the Acacias river, luminous specimens (Aequidens metae) were caught in areas with potential hydrocarbon contamination. Additionally, luminous specimens were caught in the Cuncia river as reference organisms. Liver samples were taken from each species, stored in nitrogen vapors and transported to the laboratory for evaluation. The determination of the enzymatic activity EROD was evaluated through fluorescence expressing the results in function of the protein concentration. CONCLUSIONS. The determination of EROD activity is a reliable tool to demonstrate the presence of planar compounds such as hydrocarbons and their potential effect in areas where there have not been evident and quantifiable environmental impacts.

Key words: Enzymatic activity, EROD, fish, hydrocarbons, Orinoquia. 


\title{
Plan de acción: para el mejoramiento de la producción de los pequeños productores dedicados a la actividad cuyicola en la orinoquia: actividades de implementación.
}

\section{Action plan: for the improvement of the production of small producers dedicated to cuyicola activity in the orinoquia: implementation activities.}

\author{
Pedronel Parrado Vazcoㅜ; Luis Carlos Ramírez Villa²; Angela Yineth Murcia \\ Rozo ${ }^{1}$ \\ ${ }^{1}$ Estudiante MVZ Integrante del Semillero de Investigación ECODER, \\ ${ }^{2}$ Docente Universidad de los Llanos, Grupo de Investigación Agroforestería, \\ Líder Semillero de Investigación ECODER \\ Pedronel.parrado@unillanos.edu.co \\ Icramirez@unillanos.edu.co \\ angela.murcia@unillanos.edu.co
}

\section{RESUMEN.}

INTRODUCCION. El presente proyecto se realizó como parte especifica de la propuesta de Proyección Social titulada "Fortalecimiento organizativo de los productores de Cuy (Cavias porcellus) de los Llanos Orientales, una estrategia para garantizar la seguridad alimentaria en las poblaciones rurales". En la primera fase se encontró un riesgo en la seguridad alimentaria en las zonas rurales de Villavicencio, por lo que se generó un plan de acción con la implementación de un sistema de producción de cuy que tuvo un componente de capacitación y otro de asesoría en campo. OBJETIVO. Implementar el plan de capacitación y desarrollar el plan de producción de cuyes a pequeños productores del piedemonte de la Orinoquia Colombiana. MATERIALES Y METODOS. El enfoque investigativo fue cualitativo, se realizaron procesos de Investigación Acción Participativa, primero se realizaron diferentes capacitaciones teóricas y prácticas a 12 pequeños productores del piedemonte de la Orinoquia acerca de las generalidades, 
establecimiento, manejo, nutrición y reproducción de cuye. Posteriormente se inició un proceso de asesoría en los predios de cada uno de los productores, para orientar al establecimiento de las jaulas o pozas donde recibirían la unidad productiva de cuyes, motivando al uso de materias primas obtenidas en el mismo predio, es trabajo se hizo en compañía de los productores, lo que dio paso a un proceso de priorización y selección de siete (7) familias productoras fueron beneficiados con la entrega de una unidad productiva conformada por 4 hembras y 1 macho, se realizaron visitas técnicas para evaluar el desempeño productivo de la unidad entregada y las experiencias de cada una de las familias beneficiadas.

RESULTADOS. Se logra determinar que en casi todos los casos hubo una pérdida de animales debido principalmente a un mal manejo en la nutrición, específicamente la no combinación de suplementos alimenticios como el concentrado junto con la dieta basada en forrajes verdes, lo cual causó, pérdidas de peso, decaimiento, abortos por mal nutrición entre otras causas de muerte de los animales. Se logró identificar que los productores capacitados para el establecimiento de la unidad productiva de cuyes, lograron mantener el pie de cría inicial e inclusive aumentarlo, a pesar de las pérdidas generadas, gracias a las herramientas prácticas brindadas en las capacitaciones previas, en general cada uno de ellos continúan con la iniciativa y motivación de llegar a un punto de producción en donde puedan comercializar la carne de cuy como plato especial y por consiguiente generar un ingreso para la sostenibilidad alimentaria de la familia campesina. CONCLUSIONES. Se evidenció un aporte importante en las diferentes familias que iniciaron y mejoraron el sistema de producción de cuyes estableciendo criterios óptimos para el comercio y la incorporación de la carne de cuy en la canasta familiar, como también el deseo por aumentar su producción y comercializar sus animales ya que han visto las virtudes de esta especie y sus actitudes productivas con buen manejo frente a otros sistemas de producción pecuarios que requieren más inversión para una menor ganancia. A lo largo del proyecto, los productores desarrollaron destrezas y mejoras en la cría de sus cuyes motivados por el rendimiento y los buenos índices de natalidad que lograron evidenciar. Se logró generar un vínculo entre los productores y la Universidad de 
los Llanos para continuar con el progreso de estas familias y generar una cadena aliada para lograr el comercio de estos animales.

Palabras claves: sostenibilidad, sistemas de producción, familias productoras.

\section{ABSTRACT}

INTRODUCTION. This project was carried out as a specific part of the Social Projection proposal entitled "Organizational strengthening of the guinea pig producers (Cavia porcellus) of the Eastern Plains, a strategy to guarantee food security in rural populations". In the first phase, there was a risk in food security in the rural areas of Villavicencio, so an action plan was generated with the implementation of a guinea pig production system that had a training component and a field advisory component. OBJECTIVE. Implement the training plan and develop the guinea pig production plan to small producers of Piedmont of the Colombian Orinoquia. MATERIALS AND METHODS. The research approach was qualitative, Participatory Action Research processes were carried out, first different theoretical and practical trainings were carried out to 12 small producers of the Orinoquia foothills about the generalities, establishment, management, nutrition and reproduction of guinea pigs. Subsequently, an advisory process began on the farms of each of the producers, to guide the establishment of the cages or ponds where they would receive the productive unit of guinea pigs, motivating the use of raw materials obtained on the same site, it is work was done in the company of the producers, which gave way to a process of prioritization and selection of seven (7) producing families were benefited with the delivery of a productive unit consisting of 4 females and 1 male, technical visits were made to evaluate the productive performance of the unit delivered and the experiences of each of the families benefited. RESULTS It is possible to determine that in almost all cases there was a loss of animals due mainly to poor management in nutrition, specifically the noncombination of dietary supplements such as the concentrate together with the diet based on green forages, which caused weight loss, decay, abortions due to poor 
nutrition among other causes of death of animals. It was possible to identify that the producers trained for the establishment of the guinea pig production unit, managed to maintain the initial breeding foot and even increase it, despite the losses generated, thanks to the practical tools provided in the previous trainings, in general each one of them they continue with the initiative and motivation to reach a production point where they can market guinea pig meat as a special dish and therefore generate an income for the food sustainability of the peasant family. CONCLUSIONS An important contribution was evidenced in the different families that initiated and improved the guinea pig production system establishing optimal criteria for trade and the incorporation of guinea pig meat in the family basket, as well as the desire to increase their production and market their animals since they have seen the virtues of this species and their productive attitudes with good management compared to other livestock production systems that require more investment for a lower profit. Throughout the project, the producers developed skills and improvements in the breeding of their guinea pigs motivated by performance and the good birth rates that they managed to show. It was possible to generate a link between the producers and the University of Los Llanos to continue the progress of these families and generate an allied chain to achieve trade in these animals.

Keywords: sustainability, production systems, producing families. 
Evaluación del efecto de la inclusión de tres niveles de dos cepas comerciales de probióticos sobre la morfología intestinal de alevinos de cachama blanca (Piaractus brachypomus)

\title{
Evaluation of the effect of the inclusion of three levels of two commercial strains of probiotics on the intestinal morphology of white-faced fry (Piaractus brachypomus)
}

\begin{abstract}
Aguirre- Rivera Álvaro Andrés ${ }^{1}$, Figueredo-Matheus Julieth Andrea ${ }^{2}$, Burgos-Rada Alejandro ${ }^{3}$, Ramirez-Merlano Juan Antonio ${ }^{3}$, Mira-López Tatiana María ${ }^{3}$.

${ }^{1}$ Estudiante de MVZ Universidad de los Llanos, 2 Estudiante MVZ Universidad Cooperativa de Colombia, ${ }^{3}$ Grupo de Investigación en Reproducción y Toxicología de Organismos Acuáticos - GRITOX Universidad de los Llanos. tmira@unillanos.edu.co
\end{abstract}

\section{RESUMEN}

INTRODUCCIÓN. En piscicultura, el uso de probióticos ha permitido obtener mejores resultados en el crecimiento de los peces, disminuyendo los costos de producción y el tiempo de cultivo necesario para cada ciclo de producción. La inclusión de probióticos en la dieta promueve el balance benéfico de microorganismos que hacen parte de la microbiota intestinal debido a la inhibición de proliferación de agentes patógenos, mejoramiento de la digestibilidad y de la absorción de nutrientes. OBJETIVO. Evaluar el efecto de la inclusión de tres niveles de dos cepas comerciales de probióticos sobre la morfología intestinal de alevinos de cachama blanca Piaractus brachypomus. MATERIALES $\mathbf{Y}$ MÉTODOS. Este estudio se realizó en las instalaciones del Instituto de Acuicultura y Pesca de los Llanos - Universidad de los Llanos (IALL-UNILLANOS) ubicado en la ciudad de Villavicencio, Colombia. Fueron seleccionados al azar, alevinos de la especie con 60 días de edad y distribuidos en tanques plásticos de $500 \mathrm{~L}$ de acuerdo a cada tratamiento (18 individuos por tanque). Se evaluaron por triplicado 7 tratamientos en total, que consistían en la adición de dos cepas de probióticos (Bio-mos $\AA$ y Keeton $\AA$ ) incluidos en la dieta (35\%PB) en tres niveles distintos: 2, 4 
y $6 \%$ y un tratamiento control el cual no llevaba ninguna adición de probiótico. Para la evaluación de los cambios en la morfología intestinal, se tomaron muestras de una porción del intestino al final de los experimentos, fueron fijadas en formol al $4 \%(\mathrm{pH} 7)$ y sometidas a procesos convencionales de histología y tinción en hematoxilina- eosina. En las placas histológicas se observó el estado e integridad general y se evaluaron, el número y longitud de vellosidades intestinales. Todas las observaciones y mediciones fueron realizadas con un microscopio Carl Zeizz, Cámara digital (MotiCam 2000) y un software analizador de imágenes (Motic Images Plus 2.0). RESULTADOS. La inclusión de probióticos Keeton® y Bio$\operatorname{mos}{ }^{\circledR}$ no presentaron diferencias significativas respecto al grupo control (dieta comercial sin probióticos). Sin embargo, niveles de $4 \%$ y $6 \%$ de inclusión generaron un aumento significativo en la longitud de las vellosidades de los juveniles de cachama blanca evaluados con respecto al de menor inclusión (2\%) dónde no se presentó la misma eficiencia. En cuanto a la densidad de las vellosidades por cada $500 \mu \mathrm{m}$ no se presentaron diferencias significativas en ninguno de los tratamientos evaluados. CONCLUSIONES. Los resultados obtenidos nos permiten concluir que el uso de probióticos es viable en juveniles de Cachama blanca y que su inclusión no afecta la morfología intestinal, siendo necesario evaluar parámetros productivos y de bienestar que nos permitan dilucidar si el uso de estos, podría mejorar la producción en términos de crecimiento y sobrevivencia, especialmente en aquellos tratamientos con mayores niveles de inclusión.

Este trabajo se realizó en el marco del Proyecto "INCLUSIÓN DE TRES NIVELES DE DOS CEPAS PROBIÓTICAS (Keeton® y Bio-mos®) EN LA DIETA DE ALEVINOS DE CACHAMA BLANCA (Piaractus brachypomus)" Financiado por la Dirección General de Investigaciones de la Universidad de los Llanos (C01-F01012-2016).

Palabra clave: Bio-mos $\AA$, Keeton $\AA$, Microorganismos, Acuicultura, Especies nativas 


\section{ABSTRACT}

INTRODUCTION. In aquaculture, the use of probiotics has allowed to obtain better results in fish growing, reducing production costs and breeding time for each production cycle. Its inclusion in diets promotes the beneficial balance of microorganisms that are part of the intestinal microbiota due to the inhibition of proliferation of pathogens, improvement of digestibility and nutrients absorption. OBJECTIVE. To evaluate the effect of two probiotics commercial strains at three inclusion levels on the intestinal morphology of white cachama juveniles Piaractus brachypomus. MATERIALS AND METHODS. This study was carried out in the facilities of the Instituto de Acuicultura y Pesca de los Llanos - Universidad de los Llanos (IALL-UNILLANOS) located in the city of Villavicencio, Colombia. 60 days age juveniles of the species were randomly selected and distributed in $500 \mathrm{~L}$ plastic tanks according to each treatment (18 individuals per tank). A total of 7 treatments were evaluated in triplicate, which consisted of the addition of two strains of probiotics (Bio-mos ${ }^{\circledR}$ and Keeton $\AA$ ) included in the diet $(35 \%$ PB) at three different levels: 2, 4 and $6 \%$ and one control treatment which did not carry any probiotic addition. For the evaluation of changes in intestinal morphology, samples of a portion of the intestine were taken at the end of the experiments, fixed in $4 \%$ formalin $(\mathrm{pH} 7)$ and subjected to conventional histology and staining processes in hematoxylin-eosin. In the histological plates the general state and integrity were observed and the number and length of intestinal villi were evaluated. All observations and measurements were made with a Carl Zeizz microscope, digital camera (MotiCam 2000) and image analyzer software (Motic Images Plus 2.0). RESULTS The inclusion of Keeton $\AA$ and Bio-mos $\AA$ probiotics did not show significant differences with respect to the control group (commercial diet without probiotics). However, levels of $4 \%$ and $6 \%$ of inclusion generated a significant increase in the length of the villi in the white cachama juveniles evaluated, in comparison with the lower inclusion (2\%), where the same efficiency did not occur. Regarding the density of the villi per $500 \mu \mathrm{m}$, there were no significant differences in any of the treatments evaluated. CONCLUSIONS. The 
results obtained allow us to conclude that the use of probiotics is viable in juveniles of white Cachama and that their inclusion does not affect the intestinal morphology, being necessary to evaluate productive and welfare parameters that allow us to elucidate whether the use of these could improve production in terms of growth and survival, especially in those treatments with higher levels of inclusion.

This work was carried out within the framework of the Project "INCLUSIÓN DE TRES NIVELES DE DOS CEPAS PROBIÓTICAS (Keeton® y Bio-mos®) EN LA DIETA DE ALEVINOS DE CACHAMA BLANCA (Piaractus brachypomus)" Financed by Dirección General de Investigaciones de la Universidad de los Llanos (C01-F01-012-2016).

Key words: Bio-mos ${ }^{\circledR}$, Keeton $\AA$, Microorganisms, Aquaculture, Native species 


\title{
Actividad amilolítica en el intestino del coporo \\ (Prochilodus mariae)
}

\section{Amylolytic activity in the intestine of the coporo (Prochilodus mariae)}

\author{
Martin Roger ${ }^{1}$ y Yossa Martha ${ }^{2}$ \\ ${ }^{1}$ Estudiante de Medicina Veterinaria y Zootecnia, Estudiante de Pasantia \\ Investigativa-EPI Grupo Granac-. Universidad de los Llanos. \\ ${ }^{2} Z$ Zootecnista, Dr. Mg., Profesora adscrita al Instituto de Acuicultura de los Llanos. \\ Universidad de los Llanos. \\ llanos.granac.iall@unillanos.edu.co
}

\section{RESUMEN}

INTRODUCCIÓN. Con las determinaciones enzimáticas se aporta al conocimiento de la fisiología nutricional de los peces y su capacidad para aprovechar los nutrientes lo cual permite el desarrollo de dietas en función de dicha capacidad. OBJETIVO. Determinar la actividad de la enzima amilasa y su relación con la tasa de llenado en la porción anterior del intestino del coporo, bajo condiciones experimentales. MATERIALES Y MÉTODOS. En el Instituto de Acuicultura de los Llanos en la Universidad de Los Llanos, juveniles de coporo de 126,6 g. estuvieron durante 15 días en tanques de $500 \mathrm{~L}$ a temperatura constante de $28^{\circ} \mathrm{C}$, con una dieta de $34 \%$ de proteína. Después del día 13, mediante choque térmico para insensibilización y corte medular, los peces fueron medidos, pesados y sacrificados antes $(n=16)$ y después $(n=18)$ de alimentarlos (9:00 am y 15:00 pm); el intestino fue medido y diseccionado para establecer la tasa de llenado siguiendo el método de Prejs (1978), luego la porción anterior fue conservada en nitrógeno liquido para la preparación del homogenizado crudo y posterior determinación enzimática con el kit Amilasa CNPG Liquiform LABTEST ${ }^{\circledR}$. RESULTADOS. La actividad amilolítica fue: prepandial am $=1738 \pm 498$; posprandial am $=3125 \pm 878$; preprandial $p m=1847 \pm 799$ y posprandial $p m=2097 \pm 588 \mathrm{U} / \mathrm{L}$. La menor actividad prandial coincidio con la ausencia de contenido intestinal en el $90 \%$ de los peces, 
mientras que en la mayor actividad enzimática, $60 \%$ de los peces presentaron llenado total. La relación de la actividad de la amilasa y el llenado del intestino no fue proporcional. Se observó que la actividad amilolítica se incrementó una hora despues de recibir alimento siendo más alto en el horario de la mañana. CONCLUSIONES. Los resultados sugieren que la actividad amilolítica en la porción anterior del intestino no está relacionada directamente con la cantidad de alimento consumido, aunque si puede estar relacionada la presencia de alimento con el aumento de la actividad amilolítica.

Palabras clave: peces, preprandial, posprandial, amilasa, contenido intestinal

\section{ABSTRACT}

INTRODUCTION. Enzymatic determinations contribute to the knowledge of the nutritional physiology of fish and their ability to use nutrients, which allows the development of diets based on this capacity. OBJECTIVE. Determine the activity of the enzyme amylase and its relation to the filling rate in the anterior portion of the intestine of the coporo, under experimental conditions. MATERIALS AND METHODS. At the Llanos Aquaculture Institute at the University of Los Llanos, $126.6 \mathrm{~g}$ coporo juveniles spent 15 days in $500 \mathrm{~L}$ tanks at a constant temperature of $28{ }^{\circ} \mathrm{C}$, with a $34 \%$ protein diet. After day 13 , by means of thermal shock for insensitization and spinal cutting, the fish were measured, weighed and slaughtered before $(n=16)$ and after $(n=18)$ feeding them $(9: 00$ am and 3:00 pm); The intestine was measured and dissected to establish the filling rate following the method of Prejs (1978), then the anterior portion was preserved in liquid nitrogen for the preparation of the crude homogenate and subsequent enzymatic determination with the Amilase CNPG Liquiform LABTEST® kit. RESULTS. The amylolytic activity was: prepandial am $=1738 \pm 498$; postprandial am $=3125 \pm$ 878; preprandial pm $=1847 \pm 799$ and postprandial pm $=2097 \pm 588 \mathrm{U} / \mathrm{L}$. The lower prandial activity coincided with the absence of intestinal content in $90 \%$ of 
the fish, while in the greater enzymatic activity, $60 \%$ of the fish presented total filling. The relationship of amylase activity and bowel filling was not proportional. It was observed that amylolytic activity increased one hour after receiving food being higher in the morning schedule. CONCLUSIONS. The results suggest that the amylolytic activity in the anterior portion of the intestine is not directly related to the amount of food consumed, although the presence of food may be related to the increase in amylolytic activity.

Key words: fish, preprandial, postprandial, amylase, intestinal content 


\section{Evaluación de la ganancia de peso en vacas de descarte ovariectomizadas por el método de emasculación en el piedemonte llanero.}

\section{Evaluation of weight gain in discarded cows} ovariectomized by the emasculation method in the piedmont footland

Lopez-Chaquea Cielo Almeira ${ }^{1}$; Quintana-Orduz Jorge Enrique ${ }^{1}$; Fuentes-Reyes Edgar Edilberto ${ }^{2}$

'ZOOTECNISTA, Programa de Zootecnia, Universidad Agraria de Colombia, Bogotá.

${ }^{2} \mathrm{MVZ}$, MSc, PhD, Docente Departamento de Producción animal, FCARN, Universidad de los Llanos, Villavicencio, Colombia. Semillero de Investigación METABOLISMO.

efuentes@unillanos.edu.co

\section{RESUMEN}

INTRODUCCION. La ovariotomía en hembras bovinas por vía trans vaginal, es una técnica quirúrgica simple, económica y con mínimas complicaciones post operatorias, que podría fácilmente implementarse bajo condiciones de campo, constituye entonces una alternativa que, bajo ciertas circunstancias, podría resultar beneficiosa para el productor de carne independientemente de la mayor eficiencia en la conversión de alimentos en carne, ya que el solo beneficio de manejo podría ser una ventaja interesante. OBJETIVO. Con el propósito de evaluar el efecto de la ovariectomia en vacas de despaje Cebú comercial por el método de emasculación alimentadas con pasto Brachiaria decumbens. MATERIALES Y METODOS. Utilizamos 20 bovinos con edad promedio de 9 a 11 años y peso promedio de $319 \mathrm{~kg}$, divididas en dos grupos experimentales, ovariectomizadas $(n=10)$ y no ovariectomizadas $(n=10)$ por un periodo de ceba de 120 días. La ovariectomia se realizó vía transvaginal por el método de emasculación. Se cuantifico la biomasa por metro cuadrado y se efectuó análisis bromatológico en época de lluvia y sequía; se pesaron los animales a los 0, 30, 
60, 90 y 120 días. RESULTADOS. Se evidencio una disponibilidad de materia seca de $23.1 \% ; 26.8 \%$ y proteína cruda de $5.1 \% ; 6.0 \%$ en época de lluvia y sequía respectivamente. Se calculó un déficit de proteína cruda en materia seca del pasto Brachiaria decumbens de $24.3 \%$ y $33 \%$ de Mcal para los 20 bovinos en los 120 días del periodo de ceba. Las vacas ovariectomizadas y alimentadas con pasto Brachiaria decumbens y suplementado con sal mineralizada a voluntad evidenciaron una ganancia de peso promedio de $773 \mathrm{gr}$ (7.1\%); 833gr (15\%); $803 g r$ (22.5) y 763gr (26.6)a los 30, 60, 90 y 120 días respectivamente. De otro lado las vacas no ovariectomizadas y alimentadas con pasto Brachiaria decumbens y suplementadas con sal mineralizada a voluntad evidenciaron una ganancia de peso promedio de $670 \mathrm{gr}$ (6.5\%); 697gr (13\%); $670 \mathrm{gr}(19.4 \%)$ y $620 \mathrm{gr}$ (25.2\%) a los 30,60, 90 y 120 días respectivamente. CONCLUSIONES. Por los resultados obtenidos se concluye que las vacas ovariectomizadas ganaron mayor peso en porcentaje diario en comparación con las vacas no ovariectomizadas. Con un (C.V\%) porcentaje de coeficiente de variación $(5.9-6.4 \%)$ a pesar de que estadísticamente no hubo diferencia significativa ( $p>0.05)$.

Palabra clave: Ovariectomia, emasculación, ganancia de peso, nutrición, bromatológico, Brachiaria decumbens, bovinos.

\section{ABSTRACT}

INTRODUCTION. The ovariotomy in bovine females by vaginal trans route, is a simple, economical surgical technique and with minimal postoperative complications, which could easily be implemented under field conditions, is then an alternative that, under certain circumstances, could be beneficial for the producer of meat regardless of the greater efficiency in the conversion of food into meat, since the sole benefit of handling could be an interesting advantage. OBJECTIVE. With the purpose of evaluating the effect of ovariectomy in commercial Zebu cows 
by the emasculation method fed with Brachiaria decumbens grass. MATERIALS AND METHODS. We use 20 cattle with an average age of 9 to 11 years and an average weight of $319 \mathrm{~kg}$, divided into two experimental groups, ovariectomized ( $\mathrm{n}$ $=10)$ and non-ovariectomized $(n=10)$ for a 120-day fattening period. The ovariectomy was performed transvaginally by the emasculation method. Biomass was quantified per square meter and bromatological analysis was carried out during the rainy and dry seasons; the animals were weighed at 0, 30, 60, 90 and 120 days. RESULTS A dry matter availability of $23.1 \%$ was evidenced; $26.8 \%$ and $5.1 \%$ crude protein; $6.0 \%$ in times of rain and drought respectively. A crude protein deficit in dry matter of Brachiaria decumbens grass of $24.3 \%$ and $33 \%$ of Mcal was calculated for the 20 cattle in the 120 days of the fattening period. The cows ovariectomized and fed with Brachiaria decumbens grass and supplemented with mineralized salt at will showed an average weight gain of $773 \mathrm{gr}(7.1 \%)$; $833 \mathrm{gr}$ (15\%); 803gr (22.5) and 763gr (26.6) at 30, 60, 90 and 120 days respectively. On the other hand, cows not ovariectomized and fed with Brachiaria decumbens grass and supplemented with mineralized salt at will showed an average weight gain of $670 \mathrm{gr}$ (6.5\%); 697gr (13\%); 670gr (19.4\%) and 620gr (25.2\%) at 30, 60, 90 and 120 days respectively. CONCLUSIONS. From the results obtained, it is concluded that ovariectomized cows gained greater weight in daily percentage compared to non-ovariectomized cows. With a (C.V\%) percentage of coefficient of variation (5.9 - 6.4\%) although there was no statistically significant difference ( $p>0.05)$.

Key word: Ovariectomy, emasculation, weight gain, nutrition, bromatological, Brachiaria decumbens, cattle. 


\title{
CIENCIAS AGRICOLAS
}

\section{Evaluación de parámetros de producción y componentes del racimo en el cultivar Híbrido OxG con la aplicación del ácido naftalenacético (ANA) en el Campo Experimental Palmar de las Corocoras (Cenipalma)}

\section{Evaluation of production parameters and cluster components in the OxG Hybrid cultivar with the application of naphthalenacetic acid (ANA) in the Palmar de las Corocoras Experimental Field (Cenipalma)}

\author{
Rojas Yepes Lina Fernanda ${ }^{1}$ \& Carrillo Nydia Carmen ${ }^{2}$ \\ ${ }^{1}$ Estudiante de Ingeniería Agronómica Universidad de los Llanos, \\ 2 Ingeniero Agrónomo Esp. MSc, Docente de la Universidad de los Llanos \\ lina.rojas.yepes@unillanos.edu.co \\ ncarmen@unillanos.edu.co
}

\section{RESUMEN}

INTRODUCCIÓN. Colombia es el cuarto productor mundial de aceite de palma crudo después de Indonesia, Malasia y Tailandia, no obstante, el rendimiento de producción por hectárea no es el deseado. Así pues, y considerando que la prevalencia de problemas fitosanitarios, demanda también la selección de genotipos con alguna tolerancia a enfermedades y otras características de interés agronómico, como es el caso del híbrido interespecífico OxG (Elaeis oleífera $x$ Elaeis guineensis) genotipo promisorio por su resistencia parcial a la Pudrición del Cogollo (PC), enfermedad más limitante del cultivo en el país, la investigación del sector palmicultor se encamina en proveer tecnologías eficientes y validadas que permitan incrementar la eficiencia y productividad del cultivo, entre las que actualmente se encuentra el estudio de la polinización artificial con el uso del regulador de crecimiento (ANA), como una alternativa a la polinización asistida 
tradicional, actividad indispensable en el híbrido OxG. OBJETIVO. Evaluar parámetros de producción y componentes del racimo en cultivar híbrido OxG al aplicar ácido naftalenacético (ANA) en el Campo Experimental Palmar de las Corocoras. MATERIALES Y MÉTODOS. Este trabajo se realizó en el Campo Experimental Palmar de Las Corocoras, ubicado en Paratebueno-Cundinamarca, utilizando la información registrada en el ensayo experimental durante el desarrollo del proyecto de pasantía en los meses de marzo y agosto. La evaluación del uso del ANA se realizo en un diseño completo al azar dispuesto en cuatro bloques con los siguientes tratamientos: ANA+talco (T1), ANA líquido (T2) y ANA+talco+polen (T3) y el control (T4 Polen). RESULTADOS: Para el análisis y evaluación de parámetros de producción y los componentes del racimo se utilizó la información de medidas vegetativas, muestreo y registro de producción, así como los datos de 114 análisis de racimos y 34 análisis de extracción de aceite total a racimo, información correspondiente al $48 \%$ del total esperado en el ensayo. Comparando la información mediante un análisis descriptivo no se encontraron alteraciones en el crecimiento vegetativo de las palmas tratadas con el regulador de crecimiento ANA. En la conformación del racimo, el llenado de frutos (fruit set) fue mayor en el T1 con un $73.75 \%$, seguido del T3 con un $72.04 \%$, respecto a un $64.99 \%$ del T4. Entre tanto, el aceite total a racimo fue mayor en los tratamientos con ANA, así, el mayor porcentaje de aceite a racimo correspondió al T3 con un $32.32 \%$, respecto al $26.97 \%$ del T4; en la estimación de los parámetros de producción como los racimos de fruta fresca (RFF) $\left(t h a^{-1} a n ̃ o^{-1}\right)$, el número de racimos (NR) por hectárea y el peso medio de racimos (PMR), en general, no mostraron diferencias entre los tratamientos; por el contrario se observó un incremento en el contenido de aceite (CA) en los tratamientos con ANA, siendo mayor en el T1 con 8.1 $t h a^{-1} a \tilde{n} o^{-1}$, respecto a $6.5 t h a^{-1} a \tilde{n} o^{-1}$ del tratamiento control. CONCLUSIONES. Los resultados indicaron un aumento del potencial de extracción y un incremento en el contenido de aceite de los racimos al implementar el uso del ANA, en comparación con la polinización asistida tradicional.

Palabra clave: partenocárpia, fitohormona, punto óptimo de cosecha. 


\section{ABSTRACT}

INTRODUCTION. Colombia is the fourth largest producer of crude palm oil after Indonesia, Malaysia and Thailand, however, the production yield per hectare is not as desired. Thus, and considering that the prevalence of phytosanitary problems, it also demands the selection of genotypes with some tolerance to diseases and other characteristics of agronomic interest, such as the case of the interspecific OxG hybrid (Elaeis oleífera x Elaeis guineensis) promising genotype for its resistance Partial to the rot of the Cogollo (PC), the most limiting disease of the crop in the country, the research of the palm-growing sector is aimed at providing efficient and validated technologies that allow increasing the efficiency and productivity of the crop, among which the study is currently of artificial pollination with the use of the growth regulator (ANA), as an alternative to traditional assisted pollination, an indispensable activity in the OxG hybrid. OBJECTIVE. Evaluate production parameters and components of the cluster in cultivating OxG hybrid by applying naphthalenacetic acid (ANA) in the Palmar de Las Corocoras Experimental Field. MATERIALS AND METHODS. This work was carried out in the Palmar Experimental Field of Las Corocoras, located in ParatebuenoCundinamarca, using the information recorded in the experimental trial during the development of the internship project in the months of March and August. The evaluation of the use of ANA was carried out in a randomized complete design arranged in four blocks with the following treatments: ANA + talc (T1), liquid ANA (T2) and ANA + talc + pollen (T3) and control (T4 Pollen). RESULTS. For the analysis and evaluation of production parameters and cluster components, information on vegetative measures, sampling and production record was used, as well as data from 114 cluster analyzes and 34 analyzes of total oil extraction to cluster, corresponding information to $48 \%$ of the total expected in the trial. Comparing the information through a descriptive analysis, no changes were found in the vegetative growth of the palms treated with the ANA growth regulator. In the conformation of the cluster, the filling of fruits (fruit set) was greater in T1 with $73.75 \%$, followed by T3 with $72.04 \%$, compared to $64.99 \%$ of T4. Meanwhile, total 
cluster oil was higher in ANA treatments, thus, the highest percentage of cluster oil corresponded to T3 with $32.32 \%$, compared to $26.97 \%$ of T4; in the estimation of production parameters such as fresh fruit clusters (RFF) $\left(t h a^{-1}\right.$ year $\left.\left.^{-1}\right),\right)$, the number of clusters (NR) per hectare and the average weight of clusters (PMR), in general, showed no differences between treatments; on the contrary, an increase in the oil content (CA) was observed in the ANA treatments, being higher in T1 with 8.1 ( $t h a^{-1}$ year $\left.^{-1}\right)$, compared to $6.5\left(t h a^{-1}\right.$ year $\left.^{-1}\right)$, of the control treatment. CONCLUSIONS. The results indicated an increase in the extraction potential and an increase in the oil content of the clusters when implementing the use of ANA, compared to traditional assisted pollination.

Key words: parthenocarp, phytohormone, optimal harvest point. 


\title{
Funciones de pedotransferencia para determinar la microporosidad de un typic hapludox con dos usos diferentes
}

\section{Pedotransfer functions to determine the microporosity of a hapludox typic with two different uses.}

\author{
Reyes Alvarez Edwin Esteban ${ }^{1}$ \& Parra Gonzalez Sergio David ${ }^{2}$ \\ ${ }^{1}$ Estudiante de Ingeniería Agronómica de la Universidad de los Llanos, \\ ${ }^{2}$ Ing. Agrónomo. MSc, Docente de la Universidad de los Llanos, Escuela de \\ ciencias agrícolas. \\ edwin.reyes@unillanos.edu.co \\ sdparra@unillanos.edu.co
}

\begin{abstract}
RESUMEN
La microporosidad es una propiedad de importancia agronómica por su relación con el crecimiento de las plantas, pero como otras, presenta complejidad en su determinación por el uso de equipos y/o metodologías costosas, el difícil manejo de la información, además de la variedad de metodologías propuestas. Se plantea el uso de funciones de pedotransferencia de tipo continua con regresiones lineales múltiples para estimar la microporosidad de un suelo Typic Hapludox en la vereda Barcelona de Villavicencio (Meta) usando un set de datos con 12 propiedades entre físicas y químicas, de dos lotes sometidos a diferentes usos. Se tomaron 24 puntos de muestreo por cada lote en una cuadricula de $17 \times 17 \mathrm{~m}$, creada en el software QGis $\AA$; para los procedimientos estadísticos se usó Infostat $\circledast$. El uso y manejo del suelo modifica significativamente propiedades como la capacidad de retención de humedad, el contenido de arcillas, el contenido fosforo y el $\mathrm{pH}$, las funciones de pedotransferencia permitieron estimar la microporosidad con $\mathrm{R}^{2}$ de 0,49 y 0,41 usando la capacidad de campo y la conductividad hidráulica saturada como variables regresoras; otras funciones mostraron un $R^{2}$ de 0,65 y 0,64 , donde se relacionan propiedades hidrodinámicas y fisicas como capacidad de campo y arcillas, entre otras, con un poder de predicción moderado pero con posibilidad de mejora si se incluyen más variables independientes que estén muy relacionadas
\end{abstract}


con la naturaleza de la variable dependiente. La correlación entre valores predichos por una función y los valores determinados en el set de datos, es una herramienta para la validación puesto que permite diagnosticar su poder predictivo, la correlación más alta fue de 0,77 para la capacidad de campo en función de la conductividad hidráulica saturada. Los parámetros hidrodinámicos de los suelos evaluados se pueden estimar usando funciones de pedotransferencia pero con sus respectivas mejoras.

Palabras clave: Correlación de Pearson, porosidad del suelo, propiedades físicas del suelo, regresiones lineales, $\mathrm{R}^{2}$, set de datos.

\section{ABSTRACT}

Microporosity is a property of agronomic importance due to its relation with the growth of plants, but like others, it presents complexity in its determination by the use of expensive equipment and / or methodologies, the difficult handling of information, as well as the variety of proposed methodologies. The use of continuous-type pedotransference functions with multiple linear regressions is proposed to estimate the microporosity of a Typic Hapludox soil in the Barcelona district of Villavicencio (Meta) using a data set with 12 properties between physics and chemistries, of two batches submitted to different uses. 24 sampling points were taken for each batch in a grid of $17 \times 17 \mathrm{~m}$, created in the QGis ${ }^{\circledR}$ software; for the statistical procedures, Infostat $\AA$ was used. The use and management of soil significantly modified properties such as moisture retention capacity, clay content, phosphorus content and $\mathrm{pH}$, pedotransference functions allowed to estimate microporosity with $\mathrm{R}^{2}$ of 0.49 and 0.41 using the capacity field and saturated hydraulic conductivity as return variables; other functions showed an $R^{2}$ of 0.65 and 0.64 , where hydrodynamic and physical properties are related as field capacity and clays, among others, with a moderate prediction power but with the possibility of improvement if more independent variables are included. very related to the 
nature of the dependent variable. The correlation between values predicted by a function and the values determined in the data set, is a tool for validation since it allows to diagnose its predictive power, the highest correlation was 0.77 for the field capacity according to the saturated hydraulic conductivity. The hydrodynamic parameters of the evaluated soils can be estimated using pedotransference functions but with their respective improvements.

Key words: Pearson correlation, soil porosity, soil physical properties, linear regressions, $\mathrm{R}^{2}$, data set. 


\section{Efecto de cinco métodos de adecuación de suelo sobre componentes} vegetativos y el rendimiento de la variedad fedearroz 174 en arroz secano, en la vereda santa rosa del departamento del meta

Effect of five methods of soil adaptation on vegetative components and the yield of fedearroz 174 variety in dry rice, in the Santa Rosa village of the meta department.

Morales Tejeiro Laura Viviana ${ }^{1} \&$ Cifuentes Giraldo Andrés ${ }^{2}$ ${ }^{1}$ Ingeniero Agrónomo, Estudiante Especialización Gestión Ambiental Sostenible de la Universidad de los Llanos, Grupo de Investigación Gigas 2Ingeniero Agrónomo Universidad de los Llanos laura.morales@unillanos.edu.co andresagro4@gmail.com

\section{RESUMEN}

INTRODUCCIÓN. Los planes de adecuación de suelo en el cultivo de arroz en Colombia, se encuentran preestablecidos de manera tradicional de acuerdo a las costumbres de los agricultores. La evaluación de cinco métodos de preparación de suelo frente a los componentes vegetativos y de rendimiento al establecer un cultivo de arroz pretende definir y generar resultados los cuales sirvan para realizar un ajuste más equilibrado y puntual, no solo acorde a la implementación del método más eficiente para que la planta absorba de manera eficaz los nutrientes y presente mejores rendimientos, sino también ayude a determinar la maquinaria y fertilizantes necesarios para realizar el establecimiento del cultivo disminuyendo sus costos. OBJETIVO. Evaluar el efecto de cinco métodos de adecuación de suelos sobre las propiedades físicas del suelo, componentes vegetativos y de rendimiento utilizando la variedad Fedearroz 174. MATERIALES Y MÉTODOS. la investigación se realizó en la estación experimenta Santa Rosa, ubicada en el Departamento del Meta, municipio de Villavicencio, fue llevada a cabo utilizando un diseño experimental de bloques al azar con los cinco métodos 
de preparación de suelos, realizando cuatro repeticiones; en un área total de 5000 $\mathrm{m}^{2}$, las parcelas fueron de $10 \mathrm{~m} \times 50 \mathrm{~m}$, separación entre tratamientos de 1,0 m, entre bloques de $1,5 \mathrm{~m}$. Los tratamientos evaluados en este proceso fueron: labranza convencional: dos pases de rastra y dos de pulidor (testigo), labranza vertical: 1 pase de cincel vibratorio y 1 pase de pulidor, labranza reducida: 1 pase de rastra, labranza 0 : siembra y 1 pase de pulidor (tape), labranza convencional: 1 pase de cincel, siembra y tape; se evaluaron variables de crecimiento y desarrollo; variables del componente de rendimiento; y variables del suelo, las cuales se tomaron antes, durante y luego de finalizado el ciclo del cultivo. RESULTADOS. El tratamiento un pase de cincel que la capacidad de infiltración del agua pasó de $0,1814 \mathrm{~cm} /$ hora a $0,7230 \mathrm{~cm} /$ hora, aumentando de manera significativa después de realizar adecuación de suelos, lo que indica que el implemento utilizado, des compacto el suelo hasta donde es útil para el cultivo facilitando la entrada de agua, con esto podemos identificar que la implementación de este tipo de implemento agrícola contribuye de manera satisfactoria para el mejoramiento de la capacidad de infiltración del suelo, generando las condiciones adecuadas para el establecimiento y buen desarrollo del cultivo de arroz. CONCLUSIONES. Se presentó efecto de los tratamientos de métodos de adecuación de suelo sobre los componentes vegetativos y de rendimiento de la variedad de arroz Fedearroz 174; el tratamiento con un pase de cincel más un pase de pulidor y un pase de cincel presentaron resultados positivos en la variedad Fedearroz 174, incrementando algunas de sus variables de establecimiento y de rendimiento, siendo mejores que los manejos utilizados por los agricultores. El tratamiento de preparación de un pase cincel presento un incremento en calidad molinera, mejorando el rendimiento e índice de pilada, \% de grano integral y menor porcentaje de grano partido en la variedad Fedearroz 174.

Palabras claves: Adecuación, suelo, métodos de adecuación, análisis físico. 


\section{ABSTRACT}

INTRODUCTION. The plans of adaptation of soil in the cultivation of rice in Colombia, are preset in a traditional way according to the customs of the farmers. The evaluation of five methods of soil preparation against vegetative and yield components when establishing a rice crop is intended to define and generate results which serve to make a more balanced and timely adjustment, not only according to the implementation of the most efficient method so that the plant efficiently absorbs nutrients and presents better yields, but also helps determine the machinery and fertilizers necessary to carry out the establishment of the crop, reducing its costs. OBJECTIVE. To evaluate the effect of five methods of soil adaptation on the physical properties of the soil, vegetative components and yield using the Fedearroz variety 174. MATERIALS AND METHODS. The investigation was carried out in the Santa Rosa Experiment Station, located in the Department of Meta, municipality of Villavicencio, was carried out using an experimental design of randomized blocks with the five methods of soil preparation, performing four repetitions; in a total area of $5000 \mathrm{~m} 2$, the plots were $10 \mathrm{~m} \times 50 \mathrm{~m}$, separation between treatments of $1.0 \mathrm{~m}$, between blocks of $1.5 \mathrm{~m}$. The treatments evaluated in this process were: conventional tillage: two dredge and two polisher passes (control), vertical tillage: 1 vibrating chisel pass and 1 polisher pass, reduced tillage: 1 dredge pass, tillage 0 : sowing and 1 polisher pass (tape), conventional tillage: 1 chisel pass, sowing and tape; growth and development variables were evaluated; performance component variables; and soil variables, which were taken before, during and after the end of the crop cycle. RESULTS The treatment was a chisel pass that the infiltration capacity of the water went from $0.1814 \mathrm{~cm} /$ hour to $0.7230 \mathrm{~cm} /$ hour, increasing significantly after making soil adaptation, indicating that the implement used, compact the soil to where it is useful for cultivation facilitating the entry of water, with this we can identify that the implementation of this type of agricultural implement contributes satisfactorily to the improvement of the infiltration capacity of the soil, generating the appropriate conditions for the establishment and good development of rice cultivation. CONCLUSIONS. The effect of the treatments of soil adaptation methods on the vegetative and yield 
components of the Fedearroz rice variety 174 was presented; the treatment with a chisel pass plus a polisher pass and a chisel pass presented positive results in the Fedearroz 174 variety, increasing some of its establishment and performance variables, being better than the handling used by farmers. The preparation treatment of a chisel pass showed an increase in milling quality, improving the yield and index of pile,\% of whole grain and lower percentage of broken grain in the Fedearroz 174 variety.

Keywords: Adequacy, soil, adaptation methods, physical analysis. 
Fluctuación poblacional y enemigos naturales de Loxotoma elegans (Lepidoptera: Elachistidae) en el Campo Experimental Palmar de las Corocoras, Paratebueno - Cundinamarca.

\title{
Population fluctuation and natural enemies of Loxotoma elegans
}

(Lepidoptera: Elachistidae) in the Palmar de las Corocoras Experimental

Field, Paratebueno - Cundinamarca.

\author{
Otero Marentes Carlos Alberto ${ }^{1} \&$ Mantilla Gonzales Carlos Eduardo ${ }^{2}$ \\ ${ }^{1}$ Estudiante de Ingenieria Agronomica - Universidad de los Llanos, \\ 2 Ingeniero Agronomo, MSc, PhD, Docente de la Universidad de los Llanos, \\ carlos.otero@unillanos.edu.co \\ cmcmantilla@gmail.com
}

INTRODUCCIÓN. Colombia es el primer productor de aceite de palma en América y el cuarto en el mundo. El cultivo de palma de aceite tiene presencia productiva en aproximadamente el $70 \%$ del territorio nacional reuniendo a más de 6.000 productores. El lepidóptero Loxotoma elegans es una de las principales plagas defoliadoras del cultivo de palma de aceite en la zona Oriental de Colombia. La fluctuación poblacional de insectos es afectada por factores bióticos y abióticos. El tamaño de una población y sus variaciones a lo largo del tiempo pueden ser representadas por curvas. Estas variables son importantes para la ecología, pues posibilitan la determinación de las épocas de aumento o disminución poblacional, indispensables para el éxito del manejo integrado de plagas. OBJETIVO. Determinar la fluctuación poblacional y enemigos naturales de Loxotoma elegans (Lepidoptera: Elachistidae) en el Campo Experimental Palmar de las Corocoras (CEPC), Paratebueno - Cundinamarca, teniendo en cuenta los factores bióticos y abióticos que se relacionan con la fluctuación poblacional. MATERIALES $\mathbf{Y}$ MÉTODOS. El estudio se realizó en el (CEPC), en el lote 13 con un área de 3,78 ha, cultivar Angola x Tester, siembra 2014. Este lote no fue intervenido durante el tiempo del estudio. Se realizaron muestreos semanales a 23 palmas en una hoja de los niveles foliares 9,17 y 25 , revisando la cantidad de individuos vivos y 
afectados por enemigos naturales, con el sistema de movimiento $5 \times 5$, que consistió en realizar un muestreo cada cinco palmas cada cinco líneas, siguiendo la metodóloga de estaciones fijas. A los individuos parasitados se les realizo seguimiento en el laboratorio de entomología. Adicionalmente se realizó un reconocimiento de la diversidad de la entomofauna asociada a las plantas nectaríferas con una red entomológica realizando 10 pases dobles en tres sitios de $1 \mathrm{~m}^{2}$ en cada una de las plantas nectaríferas. RESULTADOS. Los resultados de la fluctuación poblacional indican que los ciclos tardan alrededor de 11 semanas y en la medida que transcurren la población de la plaga aumenta. Esta plaga ataca todos los niveles foliares, pero con preferencia hacia los niveles 17 y 9 . Fueron registrados 10 especies de parasitoides pertenecientes a las familias Eulophidae y Braconidae, atacando once de los doce instar; los parasitoides más abundantes fueron Rhysipolis sp. y Braconidae sp.1., esta última especie se encontró visitando la nectarífera Croton trinitatis. También fueron registrados cuatro especies de depredadores de las familias Syrphidae, Carabidae y Vespidae, de esta última familia la especie Synoeca sp. se registró alimentándose de la nectarífera Urena lobata. Fueron registrados 442 especies de enemigos naturales visitando las plantas nectaríferas. CONCLUSIONES. Loxotoma elegans es afectado durante su desarrollo larval por diferentes enemigos naturales. Las poblaciones de la plaga van aumentando su población a medida que transcurre el tiempo y es donde inicia la aparición de poblaciones parasitoides. La diversidad de parasitoides encontrados ejerce una relación positiva sobre la población de larvas sanas de $L$. elegans ya que al iniciar el ciclo de la plaga la cantidad de larvas sanas es mucho mayor que al finalizar el ciclo.

Palabra clave: parasitoide, hiperparasitoide, depredador, plantas nectaríferas. 


\section{ABSTRACT}

INTRODUCTION. Colombia is the first producer of palm oil in America and the fourth in the world. Oil palm cultivation has a productive presence in approximately $70 \%$ of the national territory, bringing together more than 6,000 producers. The Loxotoma elegans Lepidoptera is one of the main defoliation pests of oil palm cultivation in the eastern part of Colombia. The population fluctuation of insects is affected by biotic and abiotic factors. The size of a population and its variations over time can be represented by curves. These variables are important for ecology, because they enable the determination of times of population increase or decrease, essential for the success of integrated pest management. OBJECTIVE. To determine the population fluctuation and natural enemies of Loxotoma elegans (Lepidoptera: Elachistidae) in the Experimental Field Palmar de las Corocoras (CEPC), Paratebueno - Cundinamarca, taking into account the biotic and abiotic factors that are related to the population fluctuation. MATERIALS AND METHODS. The study was carried out in (CEPC), in lot 13 with an area of 3.78 ha, cultivate Angola $x$ Tester, planting 2014. This lot was not intervened during the time of the study. Weekly samples were taken at 23 palms on a leaf of the leaf levels 9, 17 and 25, reviewing the number of individuals alive and affected by natural enemies, with the $5 \times 5$ movement system, which consisted of sampling every five palms every five lines, following the methodologist of fixed stations. Parasitized individuals were followed up in the entomology laboratory. Additionally, a recognition of the entomofauna diversity associated with nectariferous plants with an entomological network was made by performing 10 double passes at three sites of $1 \mathrm{~m} 2$ in each of the nectariferous plants. RESULTS. The results of the population fluctuation indicate that the cycles take about 11 weeks and as the pest population increases. This pest attacks all foliar levels, but preferably towards levels 17 and 9 . Ten species of parasitoids belonging to the Eulophidae and Braconidae families were registered, attacking eleven of the twelve instars; the most abundant parasitoids were Rhysipolis sp. and Braconidae sp.1., the latter species visits the Croton trinitatis nectariferous. Four species of predators of the 
Syrphidae, Carabidae and Vespidae families, of the latter family, the species Synoeca sp. was recorded feeding on the nectariferous Urena lobata. 442 species of natural enemies were registered visiting the nectariferous plants. CONCLUSIONS Loxotoma elegans is affected during its larval development by different natural enemies. The populations of the plague increase their population as time passes and it is where the appearance of parasitoid populations begins. The diversity of parasitoids found exerts a positive relationship on the population of healthy larvae of $L$. elegans since at the beginning of the pest cycle the amount of healthy larvae is much greater than at the end of the cycle.

Key words: parasitoid, hyperparasitoid, predator, nectariferous plants. 


\title{
Simulación de las emisiones de $\mathrm{CO}_{2}$ en sistemas productivos de Villavicencio
}

\section{Simulation of $\mathrm{CO} 2$ emissions in production systems of Villavicencio}

\author{
Silva Parra Amanda ${ }^{1}$ García Ramirez Dayra Yisel ${ }^{2}$ \\ ${ }^{1}$ Ingeniera Agrónoma MSc, PhD, Docente Universidad de los Llanos, Grupo de \\ Investigación ISAF. \\ ${ }^{2}$ Ingeniera Agrónoma Esp, Candidata MSc, Docente Universidad de los Llanos, \\ Grupo de Investigación Agricultura de Precisión. \\ asilvap@unillanos.edu.co \\ dgarcia@unillanos.edu.co
}

\section{RESUMEN}

INTRODUCCIÓN. El cambio climático es un fenómeno de afectación mundial, producido por factores antrópicos y naturales, que provocan un aumento de las emisiones de gases de efecto invernadero, principalmente el $\mathrm{CO}_{2}$ atmosférico. Las emisiones antrópicas por las actividades agropecuarias son debidas en gran parte a los cambios en los usos del suelo. Sin embargo, éstos pueden contribuir no solo a liberar carbono sino a capturarlo en el suelo. OBJETIVO. El objetivo de la presente investigación fue simular la pérdida y/o aporte de carbono orgánico del suelo, que generan algunos sistemas de producción agropecuaria de Villavicencio, Colombia, sometidos a diferentes manejos del suelo, con la finalidad de estimar las absorciones $\mathrm{y} / 0$ emisiones de $\mathrm{CO}_{2}$ a la atmósfera. MATERIALES $\mathbf{Y}$ METODOS. Se seleccionaron 3 zonas de Villavicencio, en las cuales se priorizaron los sistemas productivos representativos, éstos se caracterizaron teniendo en cuenta algunos factores relacionados con el manejo de los suelos, factor de uso de la tierra (FLU), factor de gestión o labranza (FMG), factor de aporte de residuos $(\mathrm{Fl})$, con el fin de establecer los valores por defecto dictaminados por el IPCC, asociados a las tasas de pérdidas y/o ganancias de C del suelo a la atmósfera, con una proyección a 20 años, bajo condiciones 
tropicales. Se tomaron muestras de suelo a una profundidad de $0-30 \mathrm{~cm}$ para determinar los contenidos de materia orgánica del suelo (MOS), los porcentajes de carbono orgánico (COS) y otros indicadores físico-químicos del suelo, a partir de la MOS se estimaron los stocks de carbono de referencia. Se realizó análisis de tipo multivariado con el fin de agrupar los sistemas de producción agropecuaria que capturan $\mathrm{C}$ en el suelo y absorben $\mathrm{CO}_{2}$ atmosferico. RESULTADOS. El análisis de clúster permitió formar cuatro grupos, los clúster 1 y 2, agruparon en su mayoría a sistemas productivos perennes o semi-perennes (café en sistema agroforestal, cacao, frutales con leguminosas, silvopastoriles) que por sus prácticas de manejo del suelo, que incluyen cero labranza, alto nivel de adición de residuos de cosecha, actúan como "sumideros de carbono" y absorben $\mathrm{CO}_{2}$ atmosférico. El clúster 3 agrupó a sistemas de pasturas degradadas, que actuaron como bajos retenedores de carbono y emisores de $\mathrm{CO}_{2}$, principalmente con bajo a medio aporte de residuos y cero labranza, el clúster 4, agrupo a los sistemas de monocultivos (arroz con diferente tiempo de uso, soya-maíz en rotación) que realizaban labranza convencional, con baja adición de residuos, resultando en los más altos emisores de $\mathrm{CO}_{2}$ atmosférico. CONCLUSIÓN. El secuestro de $\mathrm{C}$ del suelo es una práctica mitigadora de GEI.

Palabra clave: Cambio climático, Materia Orgánica, Sumidero de C, Uso del suelo.

\section{ABSTRACT}

INTRODUCTION. Climate change is a global phenomenon, caused by anthropic and natural factors, which cause an increase in greenhouse gas emissions, mainly atmospheric $\mathrm{CO}_{2}$. Anthropic emissions from agricultural activities are due in large part to changes in land uses. However, these can contribute not only to releasing carbon but also to capture it in the soil. OBJECTIVE. The objective of the present investigation was to simulate the loss and/or contribution of organic carbon of the 
soil, generated by some agricultural systems of Villavicencio, Colombia, subjected to different soil management, in order to estimate the absorptions and/or $\mathrm{CO}_{2}$ emissions into the atmosphere. MATERIAL AND METHODS. Three Villavicencio zones were selected, in which representative agricultural productive systems were prioritized, these were characterized taking into account some factors related to soil management, land use factor (FLU), management factor or tillage (FMG), factor of contribution of residues $(\mathrm{FI})$, in order to establish the default values by the IPCC, associated with the rates of losses and/or gains of soil $C$ to the atmosphere, with a projection to 20 years, under tropical conditions. Soil samples were taken at a depth of $0-30 \mathrm{~cm}$ to determine the contents of soil organic matter (MOS), the percentages of organic carbon (COS) and other physical-chemical indicators of soil, from the MOS were estimated the reference carbon stocks. Multivariate type analysis was carried out in order to group the productive systems that capture $C$ in the soil and absorb atmospheric $\mathrm{CO}_{2}$. RESULTS. Cluster analysis allowed forming four groups, clusters 1 and 2, mostly grouped perennial or semi-perennial productive systems (coffee in agroforestry systems, cocoa, fruits with legumes, silvopastoral), that for their soil management practices, which include zero tillage, high addition of crop residues to the soil, act as "carbon sinks", clusters 3 grouped systems of degraded pastures, that act as low carbon retainer and $\mathrm{CO}_{2}$ emitters, mainly with low to medium waste and zero tillage and Cluster 4, grouped the monoculture systems (rice with different use time, soybean in rotation mainly), that made conventional tillage and little addition of crop residues resulting in emitters of atmospheric $\mathrm{CO}_{2}$. CONCLUSION. C sequestration of soil is a mitigation $\mathrm{GHG}$ practice.

Keyword: Climate change, Organic matter, C sink, Land use. 


\title{
Evaluación de la eficiencia energética del cuesco de cacay (Caryodendron Orinocense)
}

\section{Energy efficiency evaluation of cacay's shell (Caryodendron Orinocense)}

\author{
González Álvarez, Angie Carolina1, Rodríguez Jiménez, Luis Alejandro", \\ López Muñoz Luis Gilberto² \& Laguna Chacón, Jaime ${ }^{2}$ \\ ${ }^{1}$ Ingeniero(a) Agroindustrial, Universidad de los Llanos \\ ${ }^{2}$ Ingeniero Agroindustrial, Docente de la Universidad de los Llanos, Grupo de \\ Investigación Ciencia, Tecnología e Innovación Agroindustrial (CITIA) \\ luis.rodriguez.jimenez@unillanos.edu.co
}

\section{RESUMEN}

INTRODUCCIÓN. El uso de combustibles no renovables ha generado un impacto negativo en el ambiente, esta situación implica el deterioro de los diferentes ecosistemas. Paralelamente la acumulación de la biomasa resultante de la industrialización de algunos productos también puede generar un impacto negativo en el equilibrio del medio ambiente. Por otra parte el Cacay (Caryodendron Orinocense) es un fruto promisorio de la Orinoquia colombiana por sus propiedades cosméticas y alimenticias con una producción de cuesco por hectárea de $11.666,2 \mathrm{~kg}$ por año. Actualmente el establecimiento del cultivo de cacay se encuentra en sus fases iniciales, se proyecta con gran crecimiento debido a su alta demanda en el mercado cosmético. OBJETIVO. Evaluar la eficiencia energética del cuesco del cacay en función del tipo de secado y tamaño de partícula mediante un proceso de combustión adiabático y establecer un análisis comparativo de los resultados obtenidos del poder calorífico del cuesco del cacay frente a los datos registrados de otras biomasas residuales (bagazo de caña de azúcar, cascarilla de arroz y cuesco de palma de aceite). MATERIALES Y MÉTODOS. El cuesco de Cacay se obtuvo de cultivos ubicados en el municipio de Puerto Gaitán, se sometieron a un proceso de limpieza donde se retiró cualquier suciedad y a un proceso de tamizado empleando un juego de tamices de la marca 
FISHER SCIENTIFIC COMPANY, teniendo en cuenta la norma ASTM-E11, luego fueron sometidos a una de reducción de tamaño por medio de un molino de discos eléctrico equipado con un motor de $0,75 \mathrm{Kw}$ de potencia, y a un estudio granulométrico para identificar los tamaños de partícula de mayor proporción y seleccionar las fracciones objeto de estudio. Una vez obtenidos los tamaños de partícula, las muestras se secaron por horno y por medio de secado natural y se denominaron como T1, T2, T3, T4 de acuerdo a los tamaños de partícula y al tipo de secado, a continuación se procedió a estimar la energía empleada para cada proceso, y se procedió a determinar el poder calorífico de las muestras por medio de una bomba calorimétrica modelo 1341 de la marca Parr. RESULTADOS. Se determinó que la muestra T2 presentó los valores más altos de poder calorífico alcanzando $4629 \mathrm{Kcal} / \mathrm{Kg}$, sin embargo, esta muestra requirió en sus pretratamientos de secado al horno y molienda un consumo de energía de 6205,5 $\mathrm{Kcal} / \mathrm{Kg}$ mucho mayor a la energía obtenida, lo que la convierte a su vez en la muestra con mayor gasto energético, por otra parte la muestra con mayor eficiencia entre el consumo de energía de sus pretratamientos y la energía generada fue la muestra T4 alcanzando un poder calorífico de $4465 \mathrm{Kcal} / \mathrm{kg}$ consumiendo $14,61 \mathrm{Kcal} / \mathrm{Kg}$ en sus pretratamientos de secado al sol y de molienda. CONCLUSIONES. El cuesco de Cacay es capaz de alcanzar altos valores energéticos en comparación con otros residuos agroindustriales tradicionales como el bagazo de la caña, la cascarilla de arroz y el cuesco de la palma de aceite, sin necesidad de emplear algún pretratamiento.

Palabra clave: Eficiencia energética, Cacay, Poder calorífico. 


\section{ABSTRACT}

INTRODUCTION. The use of non-renewable fuels has generated a negative impact on the environment, this situation implies the deterioration of the different ecosystems. At the same time, the accumulation of biomass resulting from the industrialization of some products can also generate a negative impact on the balance of the environment. On the other hand, Cacay (Caryodendron Orinocense) is a promising fruit of the Colombian Orinoquia for its cosmetic and nutritional properties with a production of cuesco per hectare of $11,666.2 \mathrm{~kg}$ per year. Currently the establishment of the cacay crop is in its initial stages, it is projected with great growth due to its high demand in the cosmetic market. OBJECTIVE. Evaluate the energy efficiency of the Cacay's shell according to the type of drying and particle size through an adiabatic combustion process and establish a comparative analysis of the results obtained from the calorific value of the cocoa husk against the recorded data of other residual biomass (sugarcane bagasse, rice husk and oil palm husk). MATERIALS AND METHODS. Cacay's shell was obtained from crops located in the municipality of Puerto Gaitán, underwent a cleaning process where any dirt was removed and a sieving process using a set of sieves of the FISHER SCIENTIFIC COMPANY brand, taking into account the standard ASTM-E11, then underwent a size reduction by means of an electric disk mill equipped with a $0.75 \mathrm{~kW}$ power motor, and a particle size study to identify the particle sizes of greater proportion and select the fractions object of study Once the particle sizes were obtained, the samples were dried by oven and by means of natural drying and were designated as T1, T2, T3, T4 according to the particle sizes and the type of drying, then we proceeded to estimate the energy used for each process, and the calorific value of the samples was determined by means of a 1341 Parr calorimetric pump. RESULTS It was determined that the T2 sample had the highest values of calorific value reaching $4629 \mathrm{Kcal} / \mathrm{Kg}$, however, this sample required an energy consumption of $6205.5 \mathrm{Kcal} / \mathrm{Kg}$ in its pretreatment of oven drying and grinding much higher than the obtained energy, which in turn 
makes it the sample with the highest energy expenditure, on the other hand the sample with the highest efficiency between the energy consumption of its pretreatments and the energy generated was the T4 sample reaching a calorific value of $4465 \mathrm{Kcal} / \mathrm{kg}$ consuming $14.61 \mathrm{Kcal} / \mathrm{Kg}$ in its sun-drying and grinding pretreatments. CONCLUSIONS. Cacay's shell is capable of achieving high energy values compared to other traditional residues such as cane bagasse, rice husk and oil palm shell, without the need for any pretreatment.

Keyword: Energy efficiency, Cacay, Calorific power. 


\section{Estudio de factibilidad para la creación de una empresa productora de} alimentos precocidos congelados a base del ñame (Dioscorea rotundata) en la ciudad de villavicencio-meta

\section{Feasibility study for the creation of a company producing frozen precooked foods based on yam (Dioscorea rotundata) in the city of villavicencio-meta}

Romero Robayo Olga Daniela ${ }^{1}$

${ }^{1}$ Estudiante de Ingenieria Agroindustrial Universidad de los Llanos

olga.romero@unillanos.edu.co

\section{RESUMEN}

INTRODUCCIÓN. Actualmente la producción y distribución del cultivo del ñame solo se centra localmente en la región del Caribe, debido a que no existen planes de negocio y proyección para incluir la línea de producción a nivel industrial en el país, ya que no se cuenta con estrategias de mercadeo, métodos de transformación y comercialización estandarizadas, lo que conlleva a que se le dé un consumo en forma directa sin sufrir ningún proceso de industrialización desaprovechando las propiedades y beneficios que este cultivo contiene. Por lo tanto con el estudio de factibilidad se busca realizar un análisis e interpretación del cultivo de ñame, con el fin de comprender el proceso de transformación, la importancia de este alimento para el desarrollo de un producto derivado del ñame, generando nuevas salidas en el mercado para este cultivo. OBJETIVO. Realizar un estudio de factibilidad para la elaboración y comercialización de productos precocidos congelados derivados del Ñame (Dioscorea rotundata), que permita fortalecer el mercado local en la ciudad de Villavicencio-Meta. MATERIALES Y MÉTODOS. Este proyecto se realizara en la Ciudad de Villavicencio, Meta, mediante una técnica de investigación documental, realizando la revisión 
bibliográfica y ubicación teórica del problema de investigación, elaboración del marco teórico, estudio de mercado, técnico, legal y organizacional de la información seleccionada de diferentes fuentes de información, utilizando adecuadamente las técnicas de referencia bibliográfica y estructuración de documentos (artículos, ensayos, informes, tesis, monografías). También, mediante la investigación de campo se busca describir la información a partir del contacto directo de la población del proyecto, obteniendo la información empírica a través de una encuesta semi - estructurada, esta ofrece un marco amplio en donde suministra información que nos permiten medir variables como edad, sexo, ingresos, estrato, formación académica y precios del producto. En cuanto al enfoque cuantitativo, se realiza un estudio financiero para poder analizar los resultados de los instrumentos que se aplican para la recolección de la información con la población del proyecto, con el fin de responder a preguntas $u$ objetivos específicos que se propuso en el proyecto como evaluar un estudio financiero donde se determine los recursos económicos necesarios y los costos totales de operación del proceso productivo. RESULTADOS. Análisis del estudio de mercado sobre los alimentos precocidos congelados en Villavicencio, identificando el sector de estos productos y definiendo características del segmento, competencia y la estrategias comerciales, Comprobar con el estudio técnico las condiciones necesarias para el proceso de transformación del ñame (maquinaria, equipos y proceso de elaboración del producto), identificar el personal y el tipo de organización más adecuada para la empresa mediante el estudio administrativo y obtener la evaluación de la estrúctura financiera del proyecto, definiendo la financiación de tal forma de asegurar la rentabilidad del proyecto. CONCLUSIONES. Dar respuesta a los objetivos propuestos en el proyecto en donde se determine si es factible poner en marcha este estudio en la ciudad de Villavicencio-Meta, el cual puede ser una nueva oportunidad de negocio para la población y un nuevo producto en el mercado para este tubérculo.

Palabra clave: Ñame, Mercado, producto, estudio de factibilidad, transformación 


\section{ABSTRACT}

INTRODUCTION. Currently, the production and distribution of the yam crop is only focused locally in the Caribbean region, because there are no business plans and projections to include the production line at the industrial level in the country, since there are no strategies for marketing, standardized transformation and marketing methods, which leads to direct consumption without suffering any industrialization process wasting the properties and benefits that this crop contains. Therefore, with the feasibility study, an analysis and interpretation of the yam crop is sought, in order to understand the transformation process, the importance of this food for the development of a product derived from the yam, generating new outputs in the Market for this crop. OBJECTIVE. Carry out a feasibility study for the elaboration and commercialization of frozen pre-cooked products derived from Name (Dioscorea rotundata), which allows strengthening the local market in the city of Villavicencio-Meta. MATERIALS AND METHODS. This project will be carried out in the City of Villavicencio, Meta, through a research technique Documentary research, carrying out the literature review and theoretical location of the research problem, elaboration of the theoretical framework, and market, technical, legal and organizational study of the selected information from different sources of information, using the bibliographic reference techniques and structuring of documents (articles, essays, reports, thesis, monographs). Also, through field research seeks to describe information from direct contact of the population of the project, obtaining the in empirical training through a semi survey - structured, this offers a ma broad RCO where supplied in training we they allow variables such as age, sex, income, stratum, academic training and product prices to be measured. Regarding the quantitative approach, a financial study is carried out to analyze the results of the instruments that are applied for the collection of information with the project population, in order to answer specific questions or objectives proposed in the project. project how to evaluate a financial study where the necessary economic resources and the total operating costs of the production process are determined. RESULTS. Analysis of the market study on frozen pre- 
cooked foods in Villavicencio, identifying the sector of these products and defining characteristics of the segment, competition and commercial strategies, Check with the technical study the necessary conditions for the process of transformation of the yam (machinery, equipment and product development process), identify the personnel and the most appropriate type of organization for the company through the administrative study and obtain the evaluation of the financial structure of the project, defining the financing in order to ensure the profitability of the project. CONCLUSIONS. Respond to the objectives proposed in the project where it is determined whether it is feasible to launch this study in the city of VillavicencioMeta, which can be a new business opportunity for the population and a new product in the market for this tuber.

Key words: Yam, Market, product, feasibility study, transformation. 


\title{
Selección recurrente en arroz de sabanas (Oryza sativa L.)
}

\section{Recurrent selection in savanna rice}

\author{
Delgado Huertas Hernando ${ }^{1}$, Silva Parra Amanda ${ }^{2}$ Guarin Luis Alfonso ${ }^{2}$ \\ ${ }^{1}$ Ingeniero Agrónomo MSc, Docente Universidad de los Llanos, Grupo de \\ Investigación ISAF. \\ ${ }^{2}$ Ingeniera Agrónoma MSc, PhD, Docente Universidad de los Llanos, Grupo de \\ Investigación ISAF. \\ ${ }^{3}$ Ingeniero Agrónomo MSc, Docente Universidad de los Llanos, Grupo de \\ Investigación ISAF. \\ hdelgado@unillanos.edu.co \\ asilvap@unillanos.edu.co \\ lguarin@unillanos.edu.co
}

\section{RESUMEN}

INTRODUCCIÓN. Los métodos clásicos de mejoramiento ha estrechado la base genética del arroz. El método de pedigrí con un número limitado de progenitores élite y relacionados genéticamente, a largo plazo puede reducir la variabilidad. El desarrollo de poblaciones con amplia base genética y el uso de métodos de mejoramiento que permitan la acumulación continua de alelos favorables, podrían superar estas desventajas. La selección recurrente (SR) permite el mejoramiento de una población mediante la pirámidación de alelos favorables de diversos donantes y de origen genético diverso. Ha sido usada en Colombia por CIAT/CIRAD para el desarrollo y mejoramiento del acervo genético del arroz Oryza sativa L., tipo Japonica Tropical de secano en sabanas ácidas. OBJETIVO. Evaluar 50 líneas de arroz de Sabana (Oryza sativa I.) obtenidas mediante mejoramiento poblacional por selección recurrente en Villavicencio. MATERIALES Y MÉTODOS. Se evaluaron en bloques completos al azar con tres repeticiones, 50 líneas avanzadas de este proyecto, junto con el testigo comercial Corpoica 
Llanura 11. RESULTADOS. Se observó diferencia significativa entre líneas de arroz para las variables dependientes rendimiento de grano, días a floración, vigor e incidencia de Pyricularia en hojas y manchado de grano. Las líneas 39 y 37 de la población PCT-11, presentaron los mayores rendimientos, con 6471 y 6192 kg.ha${ }^{1}$, respectivamente, diferentes significativamente del testigo y de nueve líneas de ciclo tardío de la población PCT-4, que presentaron rendimientos muy bajos. CONCLUSIONES. Los presentes resultados muestran la utilidad de la SR en arroz de sabanas para generar líneas con alto grado de adaptación a las sabanas ácidas con mayores rendimientos, resistencia a enfermedades, y el potencial para contribuir a la diversificación de su base genética.

Palabra clave: Genotipo, ambiente, adaptación, rendimiento, sanidad.

\begin{abstract}
INTRODUCTION. The classical methods of breeding have narrowed the genetic basis of rice. The pedigree method with a limited number of elite and genetically related parents, in the long term can reduce variability. The development of populations with a broad genetic base and the use of breeding methods that allow the continuous accumulation of favorable alleles could overcome these disadvantages. Recurrent selection (SR) allows the improvement of a population through the pyramidation of favorable alleles of diverse donors and of diverse genetic origin. It has been used in Colombia by CIAT / CIRAD for the development and improvement of the genetic stock of Oryza sativa L. rice, a tropical rain-fed Japonica type in acid savannas. OBJECTIVE. Evaluate 50 lines of Savanna rice (Oryza sativa I.) obtained through population improvement through recurrent selection in Villavicencio. MATERIALS AND METHODS. They were evaluated in complete blocks at random with three repetitions, 50 advanced lines of this project, together with the commercial control Corpoica Llanura 11. RESULTS. There was a significant difference between rice lines for the dependent variables grain yield,
\end{abstract}


days to flowering, vigor and incidence of Pyricularia in leaves and grain staining. Lines 39 and 37 of the PCT-11 population had the highest yields, with 6471 and 6192 kg.ha-1, respectively, significantly different from the control and nine late cycle lines of the PCT-4 population, which presented yields very low. CONCLUSIONS. The present results show the utility of SR in savanna rice to generate lines with a high degree of adaptation to acid savannas with higher yields, resistance to diseases, and the potential to contribute to the diversification of its genetic base.

Keyword: Genotype, environment, adaptation, performance, health. 


\title{
Establecimiento del cultivo de aceite de palo (Copaifera officinalis) en la serranía de San Martin - Meta \\ Establishment of the cultivation of stick oil (Copaifera officinalis) in the San Martin mountain range - Meta
}

\author{
Hernando Rueda Correa ${ }^{1}$

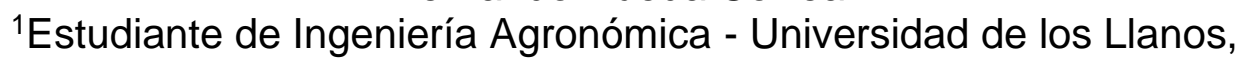 \\ hernando.rueda@unillanos.edu.co
}

\section{RESUMEN}

INTRODUCCIÓN. Las plantas Nativas son de gran importancia a nivel mundial ya que diferentes especies cuentan con diferentes usos y presentan adaptabilidad a la zona, en Colombia se encuentran algunas especies de plantas nativas, las cuales principalmente se utilizan para la alimentación, uso medicinal y como aceites, pero muy pocas son manejadas como cultivos, principalmente se encuentran las medicinales que son de gran demanda en el exterior y plantas de consumo nacional. OBJETIVO. Determinar el Potencial Productivo del Cultivo de Aceite de Palo (Copaifera officinalis) en la Serranía de San Martin - Meta. MATERIALES Y MÉTODOS. El proyecto se realizará en la serranía de San Martin (Meta), el cual consiste en realizar una primera etapa que es el establecimiento del vivero de las plantas de aceite de palo y posteriormente realizar el trasplante en una finca de la zona ya anteriormente mencionada, estableciendo la fenología, porcentaje de germinación, sobrevivencia de las plantas, la recolección de todos los datos de desarrollo que se tomaran cada 15 días, durante 1 año. Se realizará un diseño de bloques completamente al azar con 3 tratamientos y 10 repeticiones, cada parcela con un tamaño de $30 \mathrm{~m} \times 16 \mathrm{~m}$, tratamientos: el cultivo asociado en un primer caso con plátano (T1), en un segundo caso con yuca (T2), para el tercer 
tratamiento se hará sin cultivo asociado (T0), para determinar si se requiere de sombrío en la etapa juvenil de la planta. Para el T0 la distancia será de $6 \mathrm{~m} \times 3 \mathrm{~m}$, para el T1 la distancia de siembra de los árboles de aceite es igual que el T0 y entre ellos se sembrará a 3m×3m el plátano, para el T2 igual distancia de los árboles y entre ellos se sembrará a $1 \mathrm{~m} \times 1 \mathrm{~m}$ la yuca. Se llevará registro de las anormalidades presentadas para determinar que patógenos o problemas fisiológicos se presentan en las plantas, las cuales de analizaran según sea el caso en el laboratorio de microbiología. Se tomarán 15 árboles adultos ubicados en la finca de estudio para realizar la extracción del aceite, se tomarán muestras de la madera y estas, junto con el aceite se enviarán a laboratorios para realizar estudios, para establecer la calidad de estos y sus posibles usos. Seguidamente, se realizará análisis de todos los datos para determinar si el cultivo se desarrolla de una forma adecuada y tiene resultados positivos para una producción a escala en la región. RESULTADOS. Se espera que las plantas de Aceite de palo no sean afectadas por agentes patogénicos debido a su adaptabilidad a la zona, con desarrollo optimo del cultivo de aceite de palo (Copaifera oficcinalis) en la época juvenil. Se espera establecer que el aceite de palo presenta una amplia gama de usos desde el medicinal hasta el cosmético y la industria maderera y su aceite y madera son de alta calidad. CONCLUSIONES. Se espera que el árbol de aceite (Copaifera officionalis), presente un alto potencial productivo para la zona de la serranía de San Martin, debido a sus productos de alta calidad, alta adaptabilidad a la zona, bajos enemigos naturales y bajos costos de producción.

Palabra clave: Copaifera officinalis, especie nativa, serranía de san Martín, adaptabilidad, requerimientos edafoclimáticos, sistema productivo sostenible. 


\section{ABSTRACT}

INTRODUCTION. Native plants are of great importance worldwide, since different species have different uses and have adaptability to the area, in Colombia there are some species of native plants, which are mainly used for food, medicinal use and as oils, but very few are managed as crops, mainly there are medicinal products that are in great demand abroad and plants for national consumption. OBJECTIVE. To determine the productive potential of the cultivation of stick oil (Copaifera officinalis) in the range of mountains of San Martín - Meta. MATERIALS

AND METHODS. The project will be executed in the San Martín mountain range (Meta), which consists in carrying out a first stage, which is the establishment of the stick oil plant nursery and then the transplant is carried out in a farm in the area and previously mentioned, establishing the phenology, germination percentage, survival of the plants, the collection of all the development data that are taken every 15 days, for 1 year. A completely randomized block design is executed with 3 treatments and 10 repetitions, each plot with a size of $30 \mathrm{~m} \times 16 \mathrm{~m}$, treatments: the associated crop in a first case with banana (T1), in a second case with cassava (T2), for the third Treatment will be done without associated culture (T0), to determine if shadow is required in the juvenile stage of the plant. For T0 the distance will be $6 \mathrm{~m} \times 3 \mathrm{~m}$, for T1 the planting distance of the oil trees is the same as TO and between them the banana will be sown at $3 m \times 3 m$, for T2 the same distance from the trees and between them will be will sow cassava at $1 \mathrm{~m} \times 1 \mathrm{~m}$. A record of the abnormalities presented will be recorded to determine which pathogens or physiological problems occur in plants, which will be analyzed as appropriate in the microbiology laboratory. 15 adult trees located in the study farm will be taken to carry out the extraction of the oil, samples of the wood will be taken and these, together with the oil will be sent to laboratories to carry out studies, to establish the quality of these and their possible uses. Subsequently, analysis of all the data will be carried out to determine if the crop develops in an appropriate way and has positive results for a production at scale in the region. RESULTS. It is expected that Stick Oil plants will not be affected by pathogenic agents due to their 
adaptability to the area, with optimal development of the cultivation of stick oil (Copaifera Oficcinalis) in the juvenile era. It is expected to establish that stick oil has a wide range of uses from medicinal to cosmetic and wood industry and its oil and wood are of high quality. CONCLUSIONS The oil tree (Copaifera officionalis) is expected to present a high productive potential for the San Martin mountain area, due to its high-quality products, high adaptability to the area, low natural enemies and low production costs.

Key words: Copaifera officinalis, native species, range of mountains of San Martín, adaptability, edafoclimatic requirements, sustainable productive system. 


\title{
Evaluación del rendimiento en la producción de (Pleurotus Pulmonarius, Pleurotus Ostreatus) a partir de los sustratos tusa de mazorca y cacota de cacao
}

\section{Evaluation of the production performance of (Pleurotus Pulmonarius, Pleurotus Ostreatus) from tusa cob and cocoa mascot substrates}

\author{
Hernandez Rubio Debbie Zareth ${ }^{1}$,Cabrales Londoño Ericka Vanessa ${ }^{2}$,Luis \\ Gilberto Lopez Muñoz ${ }^{3}$ \\ ${ }^{1}$ Estudiante de Ingeniería agroindustrial de la Universidad de los Llanos, \\ ${ }^{2}$ Estudiante de Ingeniería agroindusrial de la Universidad de los Llanos, \\ ${ }^{3}$ Ingeniero Agroindustrial, Master estudios de desarrollo local \\ debbie.hernandez@unillanos.edu.co \\ ericka.cabrales@unillanos.edu.co
}

\section{RESUMEN}

INTRODUCCIÓN. Desde un punto de vista estrictamente nutrimental, los hongos son una magnífica fuente de alimentos debido a su alto contenido proteínico (20$30 \%$ de su biomasa seca, con todos los aminoácidos esenciales para la dieta humana), así como la presencia de vitaminas $B$ y $D$, y de quitina como fuente de fibra dietéticas. Este trabajo permitió evaluar el crecimiento y producción de Pleurotus pulmonarius, y Pleurotus ostreatus sobre dos residuos agroindustriales: tusa de mazorca y cacota de cacao, bajo condiciones ambientales, haciendo énfasis en la evaluación del rendimiento de dichas especies en los sustratos ricos es lignina en el proceso de obtención de las setas mencionadas. OBJETIVO. Evaluar el rendimiento de la producción de (Pleurotus Pulmonarius, Pleurotus Ostreatus) a partir de los sustratos tusa de mazorca y cacota de cacao.

MATERIALES Y MÉTODOS. Este proyecto se realizó en Villavicencio, Meta, las semillas utilizadas fueron Pleurotus ostreatus y Pleurotus pulmonarius, las cuales se sembraron en sustratos de cacota de cacao y tusa de mazorca; se 
establecieron estas materias primas debido a que son ricas en fibra, con alta cantidad de lignina y sin presencia de químicos, para efectuar el desarrollo del micelio. Los sustratos fueron previamente tratados con melaza, cal, y agua, los cuales fueron introducidos en bolsas de polipropileno (tubulares). Para la inoculación se utilizaron cucharas metálicas para llevar a cabo la siembra en el cultivo; en cuanto a la etapa de fructificación, para permitir la salida de los hongos al crecer, se realizaron pequeñas punzadas con agujas. Lo anterior fue realizado bajo condiciones completamente estériles. RESULTADOS. Los datos recogidos durante el desarrollo de este trabajo se analizaron para determinar la producción del hongo tipo Orellana según la mezcla inoculada, se muestra que en comparación la mezcla de orellana blanca con orellana morena presenta un $27.22 \%$ de rendimiento en la producción y mejor aprovechamiento del sustrato usado que el sustrato inoculado con solo orellana tipo morena. Se propuso igualdad de varianzas para el análisis con una confiabilidad del $95 \%$ determinando que la mezcla de semilla de orellana morena y blanca generó un rendimiento mayor y estadísticamente significativo en comparación a la semilla evaluada con solo orellana morena, puesto que presentó mayor rentabilidad superando al cultivo control en aproximadamente $318.96 \mathrm{~g}$ de peso en fresco del hongo. Indicando que si las bolsas de $1 \mathrm{~kg}$ de mezcla, se generarían en promedio $36.53 \mathrm{~g}$ en peso en fresco del hongo por oleada, por ende se recomienda la inoculación de orellanas morenas y blancas en este sustrato usado para el cultivo de orellanas. CONCLUSIONES. Se obtuvo 9,97 g de diferencia en producción de orellanas morenas y blancas con respecto a las semillas de orellanas morenas, indicándose que ambas medias obtenidas ciertamente son diferentes, pero no significativas, concluyendo en que dichas semillas la varianza fue la misma para ambas, determinando como verdadera la hipótesis nula. Ambas cajas presentan similitud entre cada una de las producciones, sin embargo, los datos obtenido de la orellana blanca y morena, tiene producciones grandes en el mismo tiempo de recolección haciendo que se presente una diferencia entre ambas semillas, pero esto no significa que el tipo de semilla incluya en el rendimiento de la producción.

Palabra clave: Inóculo, frutificaçión, orellanas, rendimento, substrato. 


\section{ABSTRACT}

INTRODUCTION. From a strictly nutritional point of view, fungi are a great source of food due to their high protein content $(20-30 \%$ of their dry biomass, with all the essential amino acids for the human diet), as well as the presence of $B$ vitamins and $D$, and chitin as a source of dietary fiber. This work allowed to evaluate the growth and production of Pleurotus pulmonius, and Pleurotus ostreatus on two agroindustrial residues: corn cob and cocoa mascot, under environmental conditions, emphasizing the evaluation of the performance of these species in rich substrates is lignin in the process of obtaining the mentioned mushrooms. OBJECTIVE Evaluate the production performance of (Pleurotus Pulmonarius, Pleurotus Ostreatus) from the Tuscan cob and cocoa mascot substrates. MATERIALS AND METHODS. This project was carried out in Villavicencio, Meta, the seeds used were Pleurotus ostreatus and Pleurotus pulmonius, which were sown on substrates of cocoa mascot and corn cob; these raw materials were established because they are rich in fiber, with a high amount of lignin and without the presence of chemicals, to effect the development of mycelium. The substrates were previously treated with molasses, lime, and water, which were introduced in polypropylene (tubular) bags. For inoculation, metallic spoons were used to carry out the planting in the crop; as for the fruiting stage, to allow the fungi to grow out, small needle punctures were made. The above was done under completely sterile conditions. RESULTS. The data collected during the development of this work were analyzed to determine the production of the Orellana type fungus according to the inoculated mixture, it is shown that in comparison the mixture of white orellana with brown orellana shows a $27.22 \%$ yield in production and better use of the substrate used than the substrate inoculated with only brown-colored orellana. Equal variances were proposed for the analysis with a 95\% reliability, determining that the mixture of brown and white orellana seed generated a higher and statistically significant yield compared to the seed evaluated with only brown orellana, since it presented greater profitability exceeding the control culture at approximately $318.96 \mathrm{~g}$ fresh weight of the fungus. Indicating that if the bags of 1 
$\mathrm{kg}$ of mixture, an average of $36.53 \mathrm{~g}$ in fresh weight of the mushroom per wave would be generated, therefore the inoculation of brown and white orellanas in this substrate used for the cultivation of orellanas is recommended. CONCLUSIONS. A difference of $9.97 \mathrm{~g}$ was obtained in the production of brown and white orellanas with respect to the seeds of brown orellanas, indicating that both means obtained are certainly different, but not significant, concluding that said seeds the variance was the same for both, determining the null hypothesis as true. Both boxes show similarity between each of the productions, however, the data obtained from the white and brown orellana, has large productions at the same time of collection causing a difference between both seeds, but this does not mean that the type of seed include in production yield.

Key words: Inoculum, fruit, orellanas, yield, substrate. 


\title{
Evaluación del comportamiento reológico y ph de una crema exfoliante corporal a base de harina de cacay (Caryodendron orinocense)
}

\section{Evaluation of the rheological behavior and ph of a body scrub cream based on cacay flour (Caryodendron orinocense)}

\author{
Pedro D. Guerrero M. ${ }^{1}$, Luis G. López M. ${ }^{2}$, Cristian C. Buitrago .M³ , Windy A. Mora \\ S. ${ }^{4}$ \\ ${ }^{1}$ Estudiante de Ingeniería Agroindustrial de la Universidad de los Llanos, \\ 2ingeniero agroindustrial, Master Estudios de Desarrollo Local \\ ${ }^{3}$ Estudiante de Ingeniería Agroindustrial de la Universidad de los Llanos, \\ ${ }^{4}$ Estudiante de Ingeniería Agroindustrial de la Universidad de los Llanos \\ pedro.guerrero@unillanos.edu.co \\ llopezm@unillanos.edu.co \\ camilo.buitrago.montenegro@unillanos.edu.co \\ windy.mora@unillanos.edu.co
}

\section{RESUMEN}

INTRODUCCIÓN. El Cacay es una de las especies más promisorias de la biodiversidad Amazónica, razón por la cual ha sido objeto de estudio de científicos e instituciones en Colombia, Venezuela, Ecuador, Perú y Brasil. Se estudia el proceso continuo de control de calidad del producto final para conocer el efecto que este posee en la piel con respecto al tiempo y la temperatura de almacenamiento. OBJETIVO. Elaborar una crema con actividad exfoliante corporal a base de harina cacay, por medio de un tamizado del fruto y evaluar el comportamiento reológico y $\mathrm{pH}$ del producto final para conocer el efecto de calidad y aceptabilidad en diferentes concentraciones (10,20 y 30\%). MATERIALES Y MÉTODOS. Se utilizaron $410 \mathrm{~g}$ de harina de cacay, la cual pasó por un proceso de tamizado con un diámetro de tamaño de partícula de $14 \mu \mathrm{m}$. Esta tiene un alto contenido de ácidos grasos poliinsaturados (75\%) como el linoleico (72,7\%), oleico 
(14\%), esteárico (4\%), palmítico (8\%) y linolénico (2,5 a 12,5\%); vitaminas E y F y retinol. A cada muestra de crema exfoliante, todas con concentraciones del $10 \%$, $20 \%$ y $30 \%$ de cacay, se les realizaron pruebas reologicas donde se determinó el $\mathrm{pH}$ y la viscosidad que estas presentaron con el transcurso de los días; para ello, se introdujo un pHmetro y un viscosímetro dentro de cada muestra que contenía $400 \mathrm{~g}$ de crema exfoliante de harina de cacay con sus respetivas concentraciones. $Y$ se finalizó realizando un seriado de encuestas sobre el comportamiento del producto a diferentes concentraciones y el efecto que este presento en los encuestados. RESULTADOS. El pH inicial finalizado el producto para la muestra 1,2 y 3 fue de $6.50,6.45$ y 6.19 respectivamente, siendo un resultado esperado, debido a que mientras más concentración de cacay posea, el pH obtenido será más bajo. se realizo un anova donde se observa que se rechaza la hipótesis nula, aceptando la hipótesis alterna, arrojando un valor de $\mathrm{P}$ inferior a alfa de 0.05 , queriendo decir que las medias no son iguales, sino diferentes, llegando a una heterogeneidad de los datos de los valores de $\mathrm{pH}$ y de viscosidad, datos tomados a diferentes días. Para las encuestas se tuvieron desviaciones estándar muy bajas, se cambiaron de una variable cualitativa a cuantitativa para poder realizar este análisis CONCLUSIONES. Según los análisis obtenidos, la crema óptima depende de cómo se desee. Debido a que en la prueba de viscosidad la crema con mayores propiedades de untabilidad y sensación en la piel fue la de concentración al $30 \%$ y según las encuestas la mejor fue la crema con concentración al 10\%.

Palabra clave: árbol amazónico, biodiversidad amazónica, cacay, exfoliante.

\section{ABSTRACT}

INTRODUCTION. Cacay is one of the most promising species of Amazonian biodiversity, which is why it has been the subject of study by scientists and institutions in Colombia, Venezuela, Ecuador, Peru and Brazil. The continuous 
process of quality control of the final product is studied to know the effect it has on the skin with respect to time and storage temperature. OBJECTIVE. To evaluate nutrient digestibility and productive parameters in broilers including Cayenne flour (Hibiscus rosa sinensis, L) without and with probiotics (Lactobacilius acidophilus) plus pectin as a replacement for the concentrate. MATERIALS AND METHODS. $410 \mathrm{~g}$ of cacay flour were used, which went through a sieving process with a particle size diameter of $14 \mu \mathrm{m}$. It has a high content of polyunsaturated fatty acids $(75 \%)$ such as linoleic $(72.7 \%)$, oleic $(14 \%)$, stearic $(4 \%)$, palmitic $(8 \%)$ and linolenic (2.5 to $12.5 \%$ ); vitamins $E$ and $F$ and retinol. Each sample of exfoliating cream, all with concentrations of $10 \%, 20 \%$ and $30 \%$ of cocoa, were rheological tests where the $\mathrm{pH}$ and viscosity that they presented with the course of the days were determined; For this, a pH meter and a viscometer were introduced into each sample that contained $400 \mathrm{~g}$ of peanut butter scrub cream with its respective concentrations. And it was completed by conducting a series of surveys on the behavior of the product at different concentrations and the effect that this presented on the respondents. OBJECTIVE. Prepare a cream with body scrub activity based on cacay flour, through a sieve of the fruit and evaluate the rheological behavior and $\mathrm{pH}$ of the final product to know the effect of quality and acceptability in different concentrations (10.20 and 30\%). MATERIALS AND METHODS. $410 \mathrm{~g}$ of cacay flour were used, which went through a sieving process with a particle size diameter of $14 \mu \mathrm{m}$. It has a high content of polyunsaturated fatty acids $(75 \%)$ such as linoleic $(72.7 \%)$, oleic $(14 \%)$, stearic $(4 \%)$, palmitic $(8 \%)$ and linolenic (2.5 to $12.5 \%$ ); vitamins $E$ and $F$ and retinol. Each sample of exfoliating cream, all with concentrations of $10 \%, 20 \%$ and $30 \%$ of cocoa, were rheological tests where the $\mathrm{pH}$ and viscosity that they presented with the course of the days were determined; For this, a pH meter and a viscometer were introduced into each sample that contained $400 \mathrm{~g}$ of peanut butter scrub cream with its respective concentrations. And it was completed by conducting a series of surveys on the behavior of the product at different concentrations and the effect that this presented on the respondents. RESULTS. The initial $\mathrm{pH}$ at the end of the product for sample 1, 2 and 3 was $6.50,6.45$ and 6.19 respectively, being an expected 
result, because the higher the concentration of cacay, the $\mathrm{pH}$ obtained will be lower. An anova was carried out where it is observed that the null hypothesis is rejected, accepting the alternate hypothesis, throwing a value of $P$ lower than 0.05 , meaning that the means are not equal, but different, reaching a heterogeneity of the data of $\mathrm{pH}$ and viscosity values, data taken at different days. For the surveys there were very low standard deviations, they changed from a qualitative variable to a quantitative one to be able to perform this analysis. CONCLUSIONS. According to the analysis obtained, the optimal cream depends on how it is desired. Due to the fact that in the viscosity test, the cream with the highest spreadability and skin sensation properties was the 30\% concentration and according to the surveys, the cream with the $10 \%$ concentration was the best.

Keyword: Amazonian tree, Amazonian biodiversity, cacay, scrub. 


\section{Propiedades químicas, físicas y biológicas del suelo, indicadores del estado de diferentes ecosistemas en una terraza alta del departamento del meta}

Chemical, physical and biological properties of the soil, indicators of the state of different ecosystems on a high terrace of the meta department

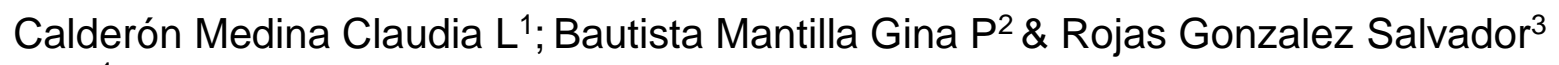

${ }^{1}$ I.A Esp. MSc. Producción Tropical Sostenible. Universidad de los Llanos

2 I.A Esp. MSc. Producción Tropical Sostenible. Universidad de los Llanos

${ }^{3}$ I.A. MSc. Investigador PhD. Agrosavia ccalderonmedina@gmail.com

ginapabado@gmail.com

srojas@agrosavia.co

\section{RESUMEN}

INTRODUCCIÓN. La calidad del suelo se ve afectada por problemas como el aumento de la densidad aparente, la compactación y la pérdida del suelo causada por la erosión, que disminuyen la productividad de los sistemas producción agrícola. Por otra parte el establecimiento de cultivos y en mayor medida la ganadería se asocia con la degradación del ecosistema por el impacto que causa en el suelo y por la presión que ha ejercido sobre el bosque consecuencia de la tala de árboles para el establecimiento de pasturas. OBJETIVO. Avanzar en la valoración de las propiedades químicas, físicas y biológicas como indicadores de calidad del suelo en un sistema agroforestal MATERIALES Y MÉTODOS. Se evaluaron tres sistemas de uso en suelos de terraza alta ubicados en el C.I La Libertad de Agrosavia: bosque, sistema agroforestal (SAF) y pradera. Se tomaron muestras de suelo a dos profundidades $0-10 \mathrm{~cm}$ (P1) y $10-20 \mathrm{~cm}$ (P2). Se midieron variables químicas y físicas y se hizo recuento microbiano de hongos, bacterias, actinomicetos y mesoinvertebrados, estos se identificaron a nivel de familia y especie. Inicialmente, se realizó análisis descriptivo de los datos y se 
interpretaron de acuerdo con los valores de referencia reportados. El análisis estadístico se realizó por medio de Análisis de Componentes Principales (ACP), análisis de varianza y prueba de comparación de medias de Duncan (para lo cual se utilizaron los software estadísticos $R$ versión 3.1.2 (paquete ADE4 1.4.5) e INFOSTAT 2014I).. RESULTADOS. Se seleccionaron las variables químicas $\mathrm{pH}$, aluminio intercambiable $(\mathrm{AlH})$, fósforo $(\mathrm{P})$, calcio $(\mathrm{Ca})$, magnesio $(\mathrm{Mg})$, potasio $(\mathrm{K})$, boro $(B)$, azufre $(\mathrm{S})$, sodio $(\mathrm{Na})$, zinc $(\mathrm{Zn})$, capacidad de intercambio catiónico efectiva (CICE) y las variables fisicas conductividad hidráulica $(\mathrm{CH})$, densidad aparente (DA), mesoporosidad (MES), porosidad total (PT), saturación (SAT), capacidad de campo (CC), humedad disponible (HD), microporosidad (MIC), punto de marchitez permanente (PMP), porcentaje de arena y arcilla, que permiten separar los sistemas en cuanto a la calidad del suelo. En el SAF se encontró moderada calidad química representada por altos valores de $\mathrm{pH}(5,30)$, bajo $\mathrm{AlH}$ $(1,02 \mathrm{Cmol} / \mathrm{kg})$, bajos contenidos de Ca en P1 $(1,49 \mathrm{Cmol} / \mathrm{kg})$ y P2 $(0,71 \mathrm{Cmol} / \mathrm{kg})$, bajo $\mathrm{Mg}$ en $\mathrm{P} 1(0,49 \mathrm{Cmol} / \mathrm{kg})$ y $\mathrm{P} 2(0,21 \mathrm{Cmol} / \mathrm{kg})$ y, los mayores valores encontrados de $S(13,08 \mathrm{mg} / \mathrm{kg})$ y $Z n(0,70 \mathrm{mg} / \mathrm{kg})$ en P2. A su vez, el SAF mostró baja calidad física con valores de DA de $1,34 \mathrm{~g} / \mathrm{cm} 3$ en P1 y $1,46 \mathrm{~g} / \mathrm{cm} 3$ en P2. CONCLUSIONES. Los indicadores físicos y químicos seleccionados permitieron diferenciar entre los tres sistemas de producción evaluados (Bosque, SAF y Pradera), es decir, son sensibles a los cambios en el uso del suelo. Las variables biológicas no contribuyeron a la diferenciación entre sistemas, sin embargo, el bosque arrojó un mayor número de actinomicetos y hongos micorrizicos arbusculares (HMA) asociados a una mayor asimilación de nutrientes como el P.

Palabra clave: Sistema agroforestal, SAF, bosque, pradera, indicador

\begin{abstract}
INTRODUCTION. Soil quality is affected by problems such as increased bulk density, compaction and soil loss caused by erosion, which decrease the productivity of agricultural production systems. On the other hand, the establishment of crops and, to a greater extent, livestock is associated with the
\end{abstract}


degradation of the ecosystem due to the impact it causes on the soil and the pressure it has exerted on the forest due to the felling of trees for the establishment of pastures. OBJECTIVE. Advance the assessment of chemical, physical and biological properties as indicators of soil quality in an agroforestry system MATERIALS AND METHODS. In the evaluation of the chemical, physical and biological properties as soil quality indicators for agroforestry systems, three systems of land use were valued. These systems are located in high terrace soils in the La Libertad de Agrosavia were evaluated: forest, system agroforestry (SAF) and grassland. Soil samples were taken at two depths $0-10 \mathrm{~cm}(P 1)$ and 10-20 cm (P2). Chemical and physical variables were measured, microbial counts were made of fungi, bacteria, actinomycetes and mesoinvertebrates. These organism were identified at family and species level. Initially, a descriptive analysis of the data was performed and interpreted according to the reported reference values. The statistical analysis was carried out through Principal Component Analysis (PCA), variance analysis and Duncan's mean comparison test (for which statistical software $R$ version 3.1.2 (package ADE4 1.4.5) and INFOSTAT were used. 2014I). RESULTS. Chemical variables were selected: $\mathrm{pH}$, exchangeable aluminum $(\mathrm{AlH})$, phosphorus $(\mathrm{P})$, calcium $(\mathrm{Ca})$, magnesium $(\mathrm{Mg})$, potassium $(\mathrm{K})$, boron $(\mathrm{B})$, sulfur $(\mathrm{S})$, sodium $(\mathrm{Na})$, zinc $(\mathrm{Zn})$, effective cation exchange capacity (CICE) and the physical variables hydraulic conductivity $(\mathrm{CH})$, bulk density (DA), mesoporosity (MES), total porosity (PT), saturation (SAT), field capacity (CC), available humidity $(\mathrm{HD})$, microporosity (MIC), permanent wilting point (PMP), percentage of sand and clay, which allow to separate the systems in terms of soil quality. In the SAF, moderate chemical quality was found, represented by high $\mathrm{pH}$ values (5.30), low AlH $(1.02 \mathrm{Cmol} / \mathrm{kg})$, low contents of Ca in P1 $(1.49 \mathrm{Cmol} / \mathrm{kg})$ and P2 $(0,71 \mathrm{Cmol}$ / $\mathrm{kg})$, under $\mathrm{Mg}$ in $\mathrm{P} 1(0.49 \mathrm{Cmol} / \mathrm{kg})$ and $\mathrm{P} 2(0.21 \mathrm{Cmol} / \mathrm{kg})$ and, the highest values found of $S(13.08 \mathrm{mg} / \mathrm{kg})$ and $Z n(0.70 \mathrm{mg} / \mathrm{kg})$ in $P 2$. In turn, the SAF showed low physical quality with DA values of $1.34 \mathrm{~g} / \mathrm{cm} 3$ in $P 1$ and $1.46 \mathrm{~g} / \mathrm{cm} 3$ in P2. CONCLUSIONS The selected physical and chemical indicators allowed us to differentiate between the three production systems evaluated (forest, system agroforestry (SAF) and grassland), that is, they are sensitive to changes in land 
use. The biological variables did not contribute to the differentiation between systems, however, the forest showed a greater number of actinomycetes and arbuscular mycorrhizal fungi (AMF) associated with greater assimilation of nutrients such as $P$

Key words: Agroforestry system, SAF, forest, grassland, indicator. 


\title{
Potencial de repelencia de algunos extractos vegetales sobre el control de Spodoptera frugiperda Smith (Lepidoptera: Noctuidae) EN MAIZ (Zea mays)
}

\section{Repellency potential of some plant extracts on the control of Spodoptera frugiperda Smith (Lepidoptera: Noctuidae) IN CORN (Zea mays)}

\author{
Lozano Mojica Sandra Katherine ${ }^{1}$ \& Zambrano Morales Angie Lizeht ${ }^{2}$ \\ ${ }^{1}$ Ingeniera agronoma Universidad de los Llanos \\ ${ }^{2}$ Ingeniera agronoma Universidad de los Llanos Esp. Geomatica Universidad \\ military \\ sandra.lozanomojica@gmail.com \\ zmalizeth@gmail.com
}

\section{RESUMEN}

INTRODUCCIÓN. La especie S. frugiperda es considerada la plaga más amenazante en el cultivo de Maíz, produce daño directo en su estado larval, esta especie logra disminuir el rendimiento fisiológico de la planta. Para el control de esta plaga se han incursionado en diferentes investigaciones para su control químico y biológico, siendo de más alta eficacia en su control químico el ingrediente activo Clorpirifós y Bacillus thuringiensis como control biológico. En el manejo del cultivo de maíz se incluyen las aplicaciones de control fitosanitario de plagas en donde se hace una gran inversión por hectárea para la regulación de S. frugiperda, las variedades de siembra tardía son las más afectadas, ya que requieren hasta 3 aplicaciones de insecticidas, lo que implica un gasto de insumos de síntesis química que aumentan el efecto tóxico al medio ambiente. Conveniente a la situación se evalúa el concepto de alelopatía como un fenómeno biológico por el cual un organismo produce uno o más compuestos bioquímicos que influyen en el crecimiento, supervivencia o reproducción de otros organismos, en función a este fenómeno que ocurre naturalmente someteremos a hipótesis una solución alternativa en el control de $\mathrm{S}$. frugiperda donde se evaluaron los efectos 
alelopáticos de algunas especies de plantas que abundan en el agro ecosistema y que por la misma razón se convierten en un recurso viable dentro de los costos de producción y un manejo apropiado del cultivo de maíz OBJETIVO. Evaluar el potencial de repelencia de extractos vegetales Higuerilla (Ricinus communis), Clavelito de playa (Wedelia trilobata), Falso cordón de fraile (Hyptis capitata), Venadillo (Conyza bonariensis), Chimú (Nicotiana tabacum), Pringamoza (Urtica sp.), Ruda (Ruta sp.), Siparuna (Siparuna sp.), Verbena (Verbena officinalis.), Lantana (Lantana camara), Falso añil (Indigofera tinctoria). sobre el control de Spodoptera frugiperda en el cultivo de maíz (Zea mays).MATERIALES Y MÉTODOS La investigación se llevó a cabo en la granja de la Universidad de los Llanos y los extractos se realizaron en el laboratorio de microbiología de la Universidad de los Llanos los dos ubicados en el Municipio de Villavicencio donde se realizo una siembra mecanizada del cultivo del maiz , una vez sembrado el cultivo se fracciono el terreno en parcelas de 3 surcos con 15 metros de longitud por tratamiento, para un total de 12 tratamientos (más 2 testigos).con la obtención de los 12 extractos vegetales elaborados a través de un método sencillo en el laboratorio se realizo la aplicación a una periodicidad de cada 2 semanas en una dosis de $80 \mathrm{ml}$ por bombada de $2 \mathrm{~L}$ se realizando 3 aplicaciones, (21 nov , 10 dic 21 dic del 2015). Para las evaluaciones de sanidad de las plantas se tomaron 5 fechas de monitoreo, (28 Nov, 10 Dic, 21 Dic, del 2015 y 4 Ene, 14 Ene, del 2016). Se estandarizaron 3 caracteres descriptivos (Altura, número de hojas y daño). RESULTADOS. Todos los extractos utilizados presentaron efecto de reducción de daño causado por Spodoptera frugiperda comparados con el testigo externo sin aplicación, el menor valor de daño causado por este insecto se observó en ruda con $12,33 \%$ siendo similar estadísticamente a verbena, clavelito, ortiga y lantana los cuales presentaron valores de daño de 22,00\%; 24,67\%; $26,53 \%$ y $28,00 \%$ respectivamente. Estos tratamientos mencionados presentaron diferencias estadísticas con el testigo externo,el tratamiento con Ruda presento diferencias estadísticas con el testigo externo y los tratamientos Venadillo, Falso añil, Higuerilla, chimú, extractos de Toronja, el testigo interno, Siparuna y falso Cordón.

CONCLUSIONES. La parcela que presento menor nivel de daño fue la tratada con 
extracto de Ruda por lo cual lo consideramos que es la especie vegetal con mayor potencial repelente sobre el control del gusano cogollero del maíz. El impacto económico estima que el uso alternativo de extractos vegetales demuestra una evidente reducción en los costos de manejo por hectárea, que expresado en porcentajes determina un $16.5 \%$ menos de inversión frente al control con Clorpirifos, la Ruda (Ruta Graveolens.), Verbena. (Verbena Officinalis L), Clavelito. (Wedelia Trilobata), son especies vegetales con una producción de metabolitos secundarios con propiedades insecticidas potencialmente utilizables para el control de Spodoptera frugiperda.

Palabra clave: Alelopatia, maiz, extractos, plaga, control biologico.

\begin{abstract}
NTRODUCTION. The S. frugiperda species is considered the most threatening pest in the cultivation of corn, produces direct damage in its larval state, this species manages to decrease the physiological performance of the plant. In order to control this pest, different investigations have been entered into for its chemical and biological control, the active ingredient Chlorpyrifos and Bacillus thuringiensis being the most effective in its chemical control as a biological control. In the management of corn cultivation, phytosanitary pest control applications are included, where a large investment per hectare is made for the regulation of $S$. frugiperda, late sowing varieties are the most affected, since they require up to 3 applications of insecticides, which implies an expense of chemical synthesis inputs that increase the toxic effect on the environment. Appropriate to the situation, the concept of allelopathy is evaluated as a biological phenomenon by which an organism produces one or more biochemical compounds that influence the growth, survival or reproduction of other organisms, depending on this naturally occurring phenomenon we will hypothesize a alternative solution in the control of $S$. frugiperda where the allelopathic effects of some species of plants that abound in
\end{abstract}


the agro ecosystem were evaluated and that for the same reason become a viable resource within production costs and proper crop management of corn OBJECTIVE. To assess the repellency potential of vegetable extracts Higuerilla (Ricinus communis), Beach carnation (Wedelia trilobata), False friar cord (Hyptis capitata), Venadillo (Conyza bonariensis), Chimú (Nicotiana tabacum), Pringamoza (Urtica sp.), Ruda (Ruta sp.), Siparuna (Siparuna sp.), Verbena (Verbena officinalis.), Lantana (Lantana camara), False Indigo (Indigofera tinctoria). on the control of Spodoptera frugiperda in the cultivation of corn (Zea mays). MATERIALS AND METHODS The research was carried out in the farm of the University of the Plains and the extracts were carried out in the microbiology laboratory of the University of the Plains the two located in the Municipality of Villavicencio where a mechanized planting of the corn crop was carried out, once the crop was sown the land was divided into plots of 3 rows with 15 meters in length per treatment, for a total of 12 treatments (plus 2 witnesses) .With the obtaining of the 12 vegetable extracts elaborated through a simple method in the laboratory, the application was carried out at a periodicity of every 2 weeks in a dose of $80 \mathrm{ml}$ per pump of $2 \mathrm{~L}$ with 3 applications being carried out, (Nov 21, Dec 10 , Dec 21, 2015). For the health assessments of the plants, 5 monitoring dates were taken, (Nov 28, Dec 10, Dec 21, 2015 and Jan 4, Jan 14, 2016). 3 descriptive characters were standardized (Height, number of leaves and damage) RESULTS. All the extracts used showed a damage reduction effect caused by Spodoptera frugiperda compared to the external control without application, the lowest damage value caused by this insect was observed in rue with $12.33 \%$ being statistically similar to verbena, carnation, nettle and lantana which presented damage values of $22.00 \%$; $24.67 \%$; $26.53 \%$ and $28.00 \%$ respectively. These mentioned treatments presented statistical differences with the external control, the treatment with Ruda presented statistical differences with the external control and the treatments Venadillo, False Indigo, Higuerilla, Chimu, Grapefruit extracts, the internal control, Siparuna and false Cordon. CONCLUSIONS. The plot that presented the lowest level of damage was the one treated with Ruda extract, which is why we consider it to be the plant species with the greatest repellent potential over the control of the 
corn-borne worm. The economic impact estimates that the alternative use of plant extracts demonstrates an evident reduction in management costs per hectare, which, expressed in percentages, determines $16.5 \%$ less investment compared to control with Chlorpyrifos, the Rue (Graveolens Route), Verbena. (Verbena Officinalis L), Clavelito. (Wedelia Trilobata), are plant species with a production of secondary metabolites with insecticidal properties potentially usable for the control of Spodoptera frugiperda.

Keyword: Allelopathy, corn, extracts, pest, biological control. 


\title{
PROCESOS AGROINDUSTRIALES
}

\section{Evaluación del efecto de las condiciones de cultivo sobre el crecimiento de desmodesmus opoliensis y su producción de ácidos grasos}

\author{
Evaluation on the effect of growing conditions on the growth of \\ desmodesmus opoliensis and its production of fatty acids
}

\begin{abstract}
Cristian Alejandro Burgos Rada ${ }^{1}$, Javier Alexander Jiménez Forero ${ }^{2}$ \& Juan Ramírez Merlano ${ }^{*}$

${ }^{1}$ Ingeniero Agroindustrial; ${ }^{2}$ Ingeniero Agroindustrial, MSc;

${ }^{3}$ Profesional en Acuicultura, MSc

* Grupo de Investigación sobre Reproducción y Toxicología de Organismos Acuáticos-GRITOX, Instituto de Acuicultura de los Llanos-IALL; Facultad de Ciencias Agropecuarias y Recursos Naturales, Universidad de los Llanos, Villavicencio, Meta- Colombia.

Cristian.burgos@unillanos.edu.co
\end{abstract}

\section{RESUMEN}

INTRODUCCIÓN. Las microalgas son microorganismos fotosintéticos reconocidos por la producción de vitaminas, carbohidratos, carotenoides, pigmentos y lípidos. La producción de estos componentes es afectada por parámetros de cultivo como la luminosidad, disponibilidad de nutrientes entre muchos otros. Los medios de cultivo, los cuales aportan estos micro y macronutrientes para especies autótrofas como la familia de las clorófitas, son demasiado costosos e impactan hasta en un $70 \%$ del valor comercial de un producto terminado a base de estos microorganismos, por lo que la mirada del mundo está en tratar de apostarle a estos microorganismos de forma sustentable para hacer viables los proyectos a escala industrial. OBJETIVO. El objeto de este estudio fue evaluar algunos parámetros de cultivo en Desmodesmus opoliensis y su participación en el 
crecimiento celular y en la relación de producción de ácidos grasos poliinsaturados. MATERIALES Y MÉTODOS. La experimentación fue llevada a cabo en el Instituto de Acuicultura de los Llanos (IALL) de la Universidad de los Llanos (Villavicencio, Meta), donde se aisló una cepa de microalga chlorófita y se dejó un cultivo stock (inóculo), el cual se cultivó en dos medios fertilizantes: Remital (Empresa Abocol) y Wuxal (Bayer) a diferentes dosis para determinar la curva cinética y su comportamiento con dos variables de respuesta: densidad celular y clorofilas totales. La densidad celular se midió por de conteo celular en cámara de Neubauer (Cel. $\mathrm{mL}^{-1}$ ) y las clorofilas totales por espectrofotometría ( $\mu \mathrm{g}$ de pigmentos. $\mathrm{mL}^{-1}$ ). Las condiciones de cultivo fueron rangos controlados: $25-30$ ${ }^{\circ} \mathrm{C}$ de temperatura y fotoperiodos de 12-12 h y 10-14 h (Luz-oscuridad) durante 16 días. RESULtadOS. La especie que se analizó presentó muy buen comportamiento de crecimiento, las curvas de crecimiento celular presentaron datos normales, homocedásticos y presentaron diferencias significativas en sus medias $(p<0,05)$ en el día de mayor crecimiento (Día 12). La microalga alcanzó una densidad celular máxima de $3,20 \times 10^{6}$ y una mínima de 9,50 × $10^{5}$ Células. $\mathrm{mL}^{-1}$. Por otro lado, las producciones de clorofilas totales se mantuvieron en un rango de 5,49 - 21,30 $\mu \mathrm{g} \cdot \mathrm{mL}^{-1}$. CONCLUSIONES. Se obtuvieron rendimientos de lípidos de hasta un $5 \%(\mathrm{p} / \mathrm{p})$, con ácidos grasos poliinsaturados como el ácido oleico, linoléico y a-linolénico en proporciones del 11,70, 14,20 y 25,54 por ciento respectivamente. Proponer un uso y escalamiento industrial de microalgas si es posible si se encuentran medios de cultivos tan económicos y eficientes como el Remital. Con esto, se sigue cerrando la brecha que existe entre la producción de microalgas a escala de laboratorio y a escala industrial.

Palabra clave: Ácidos grasos, microalgas, clorofila, curva cinética. 


\section{ABSTRACT}

INTRODUCTION. Microalgae are photosynthetic microorganisms recognized by the production of vitamins, carbohydrates, carotenoids, pigments and lipids. The productions of these components are affected by crop parameters such as luminosity, availability of nutrients among many others. The culture media, which contribute these micro and macronutrients for autotrophic species such as the chlorophytes family, are too expensive and impact up to $70 \%$ of the commercial value of a finished product based on these microorganisms, so that the look of the world is to try to bet on these microorganisms in a sustainable way to make projects viable on an industrial scale. OBJETIVE. The aim of this study was to evaluate some growth parameters in Desmodesmus opoliensis and their participation in cell growth and in the production relationship of polyunsaturated fatty acids. MATERIALS AND METHODS. The experimentation was carried out at the Instituto de Acuicultura de los Llanos (IALL) of the University of the Llanos (Villavicencio, Meta), where a strain of chlorophyte microalgae was isolated and a stock culture was left, which was cultivated in two fertilizer media: Remital (Abocol) and Wuxal (Bayer) in different doses to determine the kinetic curve and its behavior with two response variables: cell density and total chlorophylls. Cellular density was determined by cell counting in Neubauer chamber (Cel. $\mathrm{mL}^{-1}$ ) and total chlorophylls by spectrophotometry ( $\mu \mathrm{g}$ of pigments. $\mathrm{mL}^{-1}$ ). The cultivation conditions were controlled ranges: $25-30^{\circ} \mathrm{C}$ and $12-12 \mathrm{~h}$ and 10-14 h photoperiods (darklight) for 16 days. RESULTS. The species analyzed showed very good growth behavior, the cell growth curves presented normal, homocedastic data and presented significant differences in their means $(p<0.05)$ on the day of greatest growth (Day 12). The microalga reached a maximum cell density of $3.20 \times 10^{6}$ and a minimum of $9.50 \times 10^{5}$ Cells. $\mathrm{mL}^{-1}$. On the other hand, total chlorophyll production remained in the range of $5.49-21.30 \mu \mathrm{g} \cdot \mathrm{mL}^{-1}$. CONCLUSIONS. Lipid yields of up to $5 \%(\mathrm{w} / \mathrm{w})$ were obtained with polyunsaturated fatty acids such as oleic, linoleic and $\alpha$-linolenic acid in proportions of $11.70,14.20$ and 25.54 percent respectively. To propose a use and industrial scaling of microalgae if possible if you find fertilizers media as economical and efficient as Remital. With this, the gap between 
the production of microalgae at laboratory scale and the industrial scale is still closed.

Key words: Fatty acids, microalgae, chlorophyll, kinetic curve. 


\section{Estimación del consumo potencial de energía eléctrica mediante el uso de un modelo matemático para el departamento del vichada durante el periodo} 2019-2039.

\section{Estimation of the potential consumption of electric energy through the use of a mathematical model for the department of the vichada during the period 2019-2039.}

Aleisy Gonzalez Fernando ${ }^{1}$ Lugo López Cristóbal ${ }^{2}$ \& Londoño Agudelo Ivonne Amparo $^{3}$

${ }^{1}$ Estudiante de Licenciatura en Matemáticas y Física

${ }^{2}$ Ingeniero Agrónomo, Magister de Planificación y manejo ambiental de cuencas hidrográficas

${ }^{3}$ Licenciada en Matemáticas y Física, Magister en Docencia de las Matemáticas fernando.gonzalez@unillanos.edu.co cristoballugolopez7@unillanos.edu.co ivonne.londono@unillanos.edu.co

\section{RESUMEN}

PERS Orinoquía será la formulación de una política pública energética, en sintonía con el entorno y la visión de desarrollo regional con emprendimientos y productividad local, a partir de la generación de energía eléctrica que apoye el crecimiento y el mejoramiento de las condiciones de las comunidades locales en los departamentos de Arauca, Casanare, Meta y Vichada. Este trabajo busca aportar a PERS Orinoquía, pues la estimación del consumo de energía eléctrica entre los años 2019 y 2039, será un insumo para la creación de política pública, la formulación de proyectos de energización en donde se haga uso de energías alternativas a partir de la realidad del departamento del Vichada. Estos proyectos permitirán que la población tenga acceso a los fondos de apoyo financiero, que brinda el gobierno. Para obtener información energética en el Vichada, se realizó una investigación con enfoque cuantitativo, que permitió establecer el tipo de correlación entre distintas variables, tales como, la población total, el número de viviendas con energía eléctrica, con la variable consumo en $\mathrm{kWh} / \mathrm{mes}$ en el 
periodo 2005-2018. Con lo anterior se identificó el modelo adecuado para estimar el consumo de energía eléctrica para el departamento en el periodo 2019-2039 en diversos escenarios. En este proyecto se encontró que el consumo de energía eléctrica para el periodo 2019-2039 está entre $2201982 \mathrm{kWh} / \mathrm{mes}$ y 3117186 kWh/mes; pero para que toda la población tenga acceso a la energía eléctrica se requiere una producción de energía de $4818341.36 \mathrm{kWh} / \mathrm{mes}$ para el año 2019 y $6820975.93 \mathrm{kWh} / \mathrm{mes}$ para el año 2039.

Palabras claves: ANOVA, Vichada, Correlación, DANE, Determinación, Energización, Estimación, Modelos matemáticos, Orinoquía, PERS, PRESS, Regresión, SUI

\section{ABSTRACT}

PERS Orinoquía will be the formulation of an energy public policy, in tune with the environment and the vision of regional development with local enterprises and productivity, based on the generation of electricity that supports the growth and improvement of the conditions of local communities in the departments of Arauca, Casanare, Meta and Vichada. This work seeks to contribute to PERS Orinoquía, since the estimation of the consumption of electric energy between the years 2019 and 2039, will be an input for the creation of public policy, the formulation of energy projects where alternative energy is used from the reality of the department of Vichada. These projects will allow the population to have access to financial support funds, provided by the government. To obtain energy information in the Vichada, a quantitative approach investigation was carried out, which allowed establishing the type of correlation between different variables, such as, the total population, the number of homes with electric power, with the variable consumption in kWh / month in the 2005-2018 period. With the above, the appropriate model was identified to estimate the consumption of electric energy for the department in the period 2019-2039 in various scenarios.

In this project it was found that the electricity consumption for the period 2019-2039 is between $2201982 \mathrm{kWh} /$ month and $3117186 \mathrm{kWh} /$ month; But for the entire 
population to have access to electricity, energy production of $4818341.36 \mathrm{kWh} /$ month is required for the year 2019 and $6820975.93 \mathrm{kWh} /$ month for the year 2039.

Key words: ANOVA, Vichada, Correlation, DANE, Determination, Energization, Estimation, Mathematical models, Orinochia, PERS, PRESS, Regression, SUI 


\title{
Evaluación del salvado de arroz como ingrediente de una nueva formulación del pan de arroz
}

\section{Evaluation of rice bran as an ingredient of a new formulation of rice bread}

\author{
Luis F Quimbayo ${ }^{1}$; Daniel J. Barbosa, ${ }^{2}$ Ayza Y. Urbina ${ }^{3}$, Esp, MSc \\ ${ }^{1}$ Ingeniero Agroindustrial, \\ ${ }^{2}$ Ingeniero Agroindustrial, \\ ${ }^{3}$ Ingeniera Industrial, Esp, MSc. \\ Luis.quimbayo@unillanos.edu.co \\ Daniel.barbosa@unillanos.edu.co
}

\section{RESUMEN}

INTRODUCCIÓN. El pan de arroz es una preparación horneada con una masa elaborada a partir de harina de arroz y cuajada como ingredientes principales. Este es un producto alimenticio de tradición gastronómica que identifica al Departamento del Meta, característico de los municipios de Restrepo, San Martín y Villavicencio como un atractivo turístico para quienes visitan estos lugares. En los últimos años el sector este sector ha venido trabajando para incursionar en mercados nacionales como los almacenes de cadena e internacionales como México y Estados Unidos (Zambrano, 2014). Los productores que llevan años en el mercado, aseguran que se han visto afectados por el incremento de empresas informales (cámara de comercio, 2014). Lo anterior, afecta la calidad del producto, debido a la adición de materias primas para reducir los costos de producción. El salvado resulta ser una materia prima ideal en la elaboración de diversos productos alimentarios del sector de la panificación por su alto contenido en fibra dietaría. EL OBJETIVO del estudio fue evaluar el salvado de arroz como ingrediente de una nueva formulación del pan de arroz, estableciendo las condiciones y porcentajes adecuados en la adición de salvado para obtener "pan de arroz integral", con características similares al pan de arroz tradicional. MATERIALES Y MÉTODO. Materia prima. Se tuvo en cuenta el lugar de 
procedencia más utilizadas por los productores como referencia en la elaboración. Métodos. Análisis del pan de arroz tradicional Se efectuaron visitas técnicas a 8 empresas previamente seleccionadas por el comité administrativo del clúster, con el fin de observar el proceso del pan de arroz tradicional. Recolección de datos sobre la formulación y tiempos de elaboración. Se determinaron las condiciones y métodos de elaboración del pan de arroz tradicional. Ensayo experimental Basados en el estudio (Pacheco \& Peña) se realizará las pruebas con la adición de salvado de arroz en porcentajes de la mezcla, teniendo en cuenta solo la masa de arroz como ingrediente de reemplazo. Las variables en el diseño experimental incluyen 3 formulaciones y el testigo. En la tabla 4 se muestran los porcentajes en las variables de reemplazo. Análisis sensorial Se trabajó con base en la magnitud de una sola característica del producto. Esta escala fue presentada a los jueces como una descripción verbal de la sensación que les produce la muestra. RESULTADOS. Determinación de Humedad La adición de fibra favorece a la interacción polar entre la masa con las moléculas de agua. En una pequeña adición de salvado de arroz en la formulación no afecta significativamente la capacidad de retención de agua del producto. Análisis perfil de textura. Los parámetros de adhesividad, cohesividad, gomosidad y elasticidad no mostraron diferencias significativas durante las pruebas. En contraste con la dureza y fracturabilidad, si presentó diferencia significativa durante la investigación. Pruebas de evaluación sensorial Se obtuvo un total de 400 respuestas, de 100 personas encuestadas. El 64,3\% de las votaciones señala que todos los productos elaborados tenían una calificación de 5 "me gusta mucho" y el 4 "me gusta moderadamente" un 30\%. Esto indica que más del $80 \%$ de los encuestados afirman que el producto les parece muy bueno indistintamente de su formulación. CONCLUSIONES Las condiciones de fabricación del pan de arroz integral no difieren en el método de elaboración del pan de arroz tradicional, ya que este nuevo ingrediente es una modificación y reemplazo en las materias primas. Es posible adicionar SA indistintamente de los rangos de porcentajes estudiados, sin presentar cambios físicos significativos en la variación del producto final. El pan de arroz con adición de salvado de arroz "Pan de arroz integral" tuvo 
una buena aceptación por parte de los consumidores, quienes mostraron amplia conformidad con el producto.

\begin{abstract}
INTRODUCTION. Rice bread is a baked preparation with a dough made from rice flour and curd as the main ingredients. This is a food product of gastronomic tradition that identifies the Department of Meta, characteristic of the municipalities of Restrepo, San Martín and Villavicencio as a tourist attraction for those who visit these places. In recent years, this sector has been working to enter national markets such as chain and international stores such as Mexico and the United States (Zambrano, 2014). Producers who have been in the market for years say that they have been affected by the increase in informal companies (Chamber of Commerce, 2014). This affects the quality of the product, due to the addition of raw materials to reduce production costs. The bran turns out to be an ideal raw material in the production of various food products in the bakery sector because of its high fiber content. THE OBJECTIVE of the study was to evaluate rice bran as an ingredient of a new formulation of rice bread, establishing the appropriate conditions and percentages in the addition of bran to obtain "brown rice bread", with characteristics similar to traditional rice bread. MATERIALS AND METHOD. Raw material. The place of origin most used by the producers as a reference in the preparation was taken into account. Methods Analysis of traditional rice bread Technical visits were made to 8 companies previously selected by the administrative committee of the cluster, in order to observe the traditional rice bread process. Collection of data on the formulation and processing times. The conditions and methods of making traditional rice bread were determined. Experimental trial Based on the study (Pacheco \& Peña) the tests will be carried out with the addition of rice bran in percentages of the mixture, taking into account only the rice mass as a replacement ingredient. The variables in the experimental design include 3 formulations and the control. Table 4 shows the percentages in the replacement variables. Sensory analysis We worked based on the magnitude
\end{abstract}


of a single product characteristic. This scale was presented to the judges as a verbal description of the sensation produced by the sample. RESULTS Moisture Determination The addition of fiber favors the polar interaction between the mass and the water molecules. In a small addition of rice bran in the formulation does not significantly affect the water retention capacity of the product. Texture profile analysis. The parameters of adhesiveness, cohesiveness, rubberiness and elasticity showed no significant differences during the tests. In contrast to the hardness and fracturability, if it presented a significant difference during the investigation. Sensory evaluation tests $A$ total of 400 responses were obtained from 100 people surveyed. $64.3 \%$ of the votes indicate that all products made had a rating of 5 "I like it a lot" and 4 "I like it moderately" $30 \%$. This indicates that more than $80 \%$ of respondents state that the product seems very good regardless of its formulation. CONCLUSIONS The manufacturing conditions of brown rice bread do not differ in the traditional rice bread method, since this new ingredient is a modification and replacement in raw materials. It is possible to add SA interchangeably of the ranges of percentages studied, without presenting significant physical changes in the variation of the final product. The rice bread with the addition of rice bran "Brown rice bread" had a good acceptance by consumers, who showed broad compliance with the product. 


\title{
DESARROLLO RURAL
}

\section{Mujer campesina Sistemas de Produccion Agroecologica}

\section{Peasant Women Agroecological Production Systems}

\author{
Herrera Baquero Carlos Alberto \\ Ingeniero Agrónomo Esp. MSc, Docente de la Universidad de los Llanos, Grupo de \\ Estudio AMAS \\ cherrera@unillanos.edu.co
}

\section{RESUMEN}

La ponencia relaciona algunos resultados de la investigación realizada en la zonas del Ariari (Fuentedeoro - Meta) esta fue avalada y proyectada por proyección social de la Universidad de los Llanos, direccionado a mujeres que escogieron como modelo de desarrollo tecnológico, organizativo, de apropiación productiva y cultural del territorio que habitan la Agroecología. Los resultados responden al interrogante inicial: Cuáles son las alcances que las prácticas agroecológicas tienen para las relaciones de género en los espacios estudiados? Esta selección se contrapone a un modelo de desarrollo agrícola que favorece el monocultivo y el uso de agroquímicos apoyados en el modelo de la "Revolución Verde" y que vislumbra como sujeto de la producción y de la propiedad campesina a los hombres. Brindando así, una nueva visión holística sobre el desarrollo de los espacios de producción agraria y de vida campesina. La Agroecología acontece el diálogo de saberes, dónde el capital cultural y social depositado por las mujeres, hombres y niños del campo as fundamental como alternativo al modelo hegemónico. Se resalta entonces, a través de las experiencias estudiadas, las potencialidades que brinda la opción agroecológica para alterar las estructuras subordinadas que la cultura ha impuesto en las relaciones de género, en tanto la 
diversidad de culturas, la multifuncionalidad, el intercambio con pares, la comunicación entre propietarios de las veredas, en charlas de campo, en intercambios de experiencias, la creación de grupos productivos, entre otros, involucran una democratización de los espacios y fuerzas de poder, así como la potenciación de las capacidades y el empoderamiento económico y político de liderazgo de las mujeres, convertidas ahora en actoras de su propio destino. Se valora además, lo que este enfoque alternativo representa para quienes lo vivencian. La metodología usada se apoya en estudios de casos múltiples y en estudios de representaciones sociales.

Palabras claves: Género, Agroecología, saberes, Empoderamiento.

\begin{abstract}
The paper links some results of the research carried out in the Ariari (Fuentedeoro - Meta) areas, this was endorsed and projected by social projection of the University of Los Llanos, aimed at women who chose as a model of technological development, organizational, productive appropriation and cultural territory that inhabit Agroecology. The results answer the initial question: What are the scope that agroecological practices have for gender relations in the spaces studied? This selection is opposed to a model of agricultural development that favors the monoculture and the use of agrochemicals supported by the model of the "Green Revolution" and that glimpse as subject of production and peasant property to men. Thus providing a new holistic vision on the development of agricultural production spaces and rural life. Agroecology is the dialogue of knowledge, where the cultural and social capital deposited by women, men and children of the countryside is fundamental as an alternative to the hegemonic model. The potential of the agroecological option to alter the subordinate structures that culture has imposed on gender relations is highlighted through the experiences studied, as well as the diversity of cultures, the multifunctionality, the exchange with peers, the
\end{abstract}


communication among village owners, in field talks, in exchanges of experiences, the creation of productive groups, among others, involve a democratization of spaces and power forces, as well as the empowerment of capacities and economic and political empowerment of women's leadership, now converted into actors of their own destiny. It is also valued, what this alternative approach represents for those who experience it. The methodology used is supported by multiple case studies and studies of social representations.

Keywords: Gender, Agroecology, knowledge, Empowerment 


\title{
La producción tropical sostenible en la agricultura familiar
}

\section{Sustainable tropical production in the family agriculture}

\author{
Luis Carlos Ramirez Villa \& Constanza Yunda Romero ${ }^{2}$ \\ 1. Docente de la Universidad de los Llanos, MVZ \\ 2. Docente de la Universidad de los Llanos, Maestría en Producción Tropical \\ Sostenible \\ Icramirez@unillanos.edu.co
}

\section{RESUMEN}

INTRODUCCIÓN. en el proceso de restitución de tierras a personas en condición de desplazamiento por el conflicto armado, en el año 2008 se asignaron como UAF 25 hectáreas a 92 familias en la parcelación las Delicias en el Municipio de Puerto López, personas de escasos recursos económicos, sin oportunidad de implementar el modelo de desarrollo agroindustrial que se privilegia en la zona, siendo esto un limitante para los procesos de producción, por lo que se requirió una alternativa eficaz para el desarrollo sostenible de esta comunidad. OBJETIVO. Evaluar la transformación de las Unidades Agrícolas Familiares de las Delicias a partir de la implementación del enfoque sistémico y la agricultura tropical sostenible para la generación de procesos de desarrollo local. MATERIALES Y MÉTODOS. El abordaje metodológico se realizó desde un enfoque Cualitativo enmarcado dentro de un proceso Participativo donde se tomó la comunidad como base de las decisiones para transformar la realidad, este enfoque ha sido ampliamente divulgado por los procesos sociales de investigación cualitativa y de proyección social (Sampieri Hernandez, Fernandez Collado, \& Baptista Lucio, 2010),para lo cual se utilizó el enfoque cualitativo, con un modelo de Participación Acción en tres fases, diagnostica; aplicando una matriz de sostenibilidad con seis factores de análisis, los cuales fueron categorizados para su tabulación, por otro lado se realizó una segunda fase de capacitación; implementando la estrategia de divulgación del modelo sistémico y la producción 
tropical sostenible, y por último, una tercera fase de evaluación; identificando las prácticas de la adopción del modelo en cuanto a la integración suelo-plantaanimal-familia, visualizando el desarrollo local. RESULTADOS Y DISCUSIÓN. En la primera fase denominada diagnostica se evidencio que las personas se encontraban en un ingreso familiar de se encontraba en 6,00 USD al día, por debajo del Salario Mínimo Legal Vigente de Colombia, la fuente de este ingreso es el jornal por fuera de su Unidad Agrícola Familiar ya que un $20 \%$ de las familias analizadas realizaban procesos de agricultura sostenible, mientras que el $80 \%$ restante se dedican a la producción convencional. A través de la capacitación y modelos de extensión comunitaria como la demostración de resultado, el día de campo y el taller, se consolidó procesos de integración comunitaria se generó una comunicación entre las organizaciones sociales de la zona. Se evidenció que la sostenibilidad de las familias en cuanto a los 6 factores analizados, Humano y Social, Político, Ambiental, Económico y Administrativo y de Enfoque Sistémico aumentó en un $60 \%$ para quienes adoptaron totalmente el modelo y en un $25 \%$ con la implementación parcial de este, en tanto, quienes no lo adoptaron, obtuvieron detrimento en los mismos factores analizados. CONCLUSIONES. Ias prácticas de producción desde el enfoque sistémico y la producción tropical sostenible pueden ser una alternativa coherente que posibilita la consolidación del desarrollo local, siempre y cuando sea adoptado por parte de los pequeños productores, por tal razón, se recomienda hacer más replicas en diferentes comunidades.

Palabras clave: agricultura familiar, desarrollo local, producción tropical sostenible, sostenibilidad. 


\section{ABSTRACT}

INTRODUCTION. In the process of restitution of land to people in displacement due to the armed conflict, in 200825 hectares were assigned as UAF to 92 families in Las Delicias in the Municipality of Puerto López, people of limited economic resources, without opportunity to implement the agro-industrial development model that is privileged in the area, this being a limitation for the production processes, so an effective alternative for the sustainable development of this community was required. OBJECTIVE. to evaluate the transformation of the Family Agricultural Units of Delights from the implementation of the systemic approach and sustainable tropical agriculture for the generation of local development processes. MATERIALS AND METHODS. The methodological approach was carried out from a Qualitative approach framed within a Participatory process where the community was taken as the basis of the decisions to transform reality, this approach has been widely disseminated by the social processes of qualitative research and social projection (Sampieri Hernandez, Fernandez Collado, \& Baptista Lucio, 2010), for which the qualitative approach was used, with a three-stage Action Participation model, diagnoses; applying a sustainability matrix with six analysis factors, which were categorized for tabulation, on the other hand a second phase of training was carried out; implementing the dissemination strategy of the systemic model and sustainable tropical production, and finally, a third phase of evaluation; identifying the practices of adopting the model in terms of soil-plant-animal-family integration, visualizing local development. RESULTS AND DISCUSSION. In the first phase called diagnosis, it was evident that people were in a family income of USD 6.00 per day, below the Current Legal Minimum Wage of Colombia, the source of this income is the wage outside their Family Farming Unit since $20 \%$ of the families analyzed carried out sustainable agriculture processes, while the remaining $80 \%$ engaged in conventional production. Through training and community outreach models such as demonstration of results, field day and workshop, community integration processes were consolidated, communication was generated between the social organizations in the area. It was shown that the 
sustainability of the families regarding the 6 factors analyzed, Human and Social, Political, Environmental, Economic and Administrative and Systemic Approach increased by $60 \%$ for those who totally adopted the model and $25 \%$ with the implementation partial of this, meanwhile, those who did not adopt it, obtained detriment in the same factors analyzed. CONCLUSIONS production practices from the systemic approach and sustainable tropical production can be a coherent alternative that allows the consolidation of local development, as long as it is adopted by small producers, for this reason, it is recommended to make more replicas in different communities.

Keywords: family agriculture, local development, sustainable tropical production, sustainability. 
Resultados preliminares de la implementación de un plan de capacitación en seguridad alimentaria para la comunidad rural de CIVIPAZ, Puerto Esperanza, Municipio del Castillo - Meta.

\title{
Preliminary results of the implementation of a training plan in food security for the rural community of CIVIPAZ, Puerto Esperanza, Municipality of Castillo - Meta.
}

\author{
Mendoza, s. Mario A. Est. M.V.Z; Ramirez, V. Luis C. Msc. \\ Universidad de los Llanos \\ Departamento de producción animal \\ mario.mendoza.salgado@unillanos.edu.co
}

\section{RESUMEN}

INTRODUCCIÓN: En el Municipio del Castillo Departamento del Meta se vivió un periodo de violencia cruenta que llevó a procesos de despojo sistemático, en la Vereda de Puerto Esperanza en el año 2005 nació gracias al apoyo de organizaciones civiles y de líderes sociales desplazados la comunidad CIVIPAZ, los cuales se asentaron en esta comunidad, desde la cual poco a poco fueron ingresando a sus fincas, sin embargo desde este momento, se ha requerido procesos de seguridad alimentaria, debido a que gran parte de su cultura campesina y productiva se vio frustrada por el desplazamiento forzado. OBJETIVO: Caracterizar a los participantes, sus producciones y niveles socioeconómicos; que serán objeto de estudio en la comunidad rural del Municipio del Castillo Meta. METODOLOGíA: Investigación con enfoque Cualitativo, metodología de Investigación Acción Participativa, donde se escogió 30 familias para hacer el estudio descriptivo socieconomico de la citación de las familias del municipio para generar un plan de acción en cuanto a definir un plan de vida 
familiar. RESULTADOS Y DISCUSIÓN: En esta comunidad rural del Municipio del Castillo Meta, se puedo apreciar que la población jefa de hogar se encuentra en promedio en una edad de 45 años, la cual el 50\% de esta misma solo tiene de escolaridad la primaria y el $63,33 \%$ son mujeres; el $86,6 \%$ su actividad principal es la agricultura y la producción pecuaria de traspatio; de la cual en esta comunidad el $80 \%$ de esta producción es para autoconsumo y comercialización. CONCLUSIÓN: a pesar de las dificultades que han tenido por motivos de la violencia, el valor de la resiliencia social que existe en la comunidad permite que la actividad agropecuaria sea posible desde una mirada de la Seguridad Alimentaria, que a su vez puede ser una actividad de desarrollo local, debido a que destino de la producción es Autoconsumo y Comercialización.

Palabras Clave: Desarrollo Rural, Seguridad Alimentaria, Resiliencia.

\section{ABSTRACT}

INTRODUCTION: In the Municipality of the Castle Department of Meta there was a period of cruel violence that led to systematic dispossession processes, in the Vereda of Puerto Esperanza in 2005, the CIVIPAZ community was born thanks to the support of civil organizations and displaced social leaders, which settled in this community, from which little by little they were entering their farms, however from this moment, food security processes have been required, due to the large part of their peasant and productive culture was frustrated by forced displacement. OBJECTIVE: To characterize the participants, their productions and socioeconomic levels; which will be studied in the rural community of the Municipality of Castillo Meta. METHODOLOGY: Research with Qualitative approach, Participatory Action Research methodology, where 30 families were chosen to do the socio-economic descriptive study of the citation of the families of the municipality to generate an action plan in terms of defining a family life plan. RESULTS AND DISCUSSION: In this rural community of the Municipality of Castillo Meta, the head of the household population can be evaluated on average 
at an age of 45 , which $50 \%$ of the same has only primary schooling and $63,33 \%$ are women; $86.6 \%$ of its main activity is agriculture and backyard livestock production; Of the quality in this community, $80 \%$ of this production is for selfconsumption and exports.CONCLUSION: in spite of the difficulties they had due to violence, the value of social resilience that exists in the community allows agricultural activity to be possible from a Food Security perspective, which in turn can be an activity of local development, because the destination of production is Self-consumption and Marketing.

Keywords: Rural Development, Food Security, Resilience. 


\title{
Fortalecimiento productivo a los criadores de Cuy (Cavias porcellus) del trópico húmedo colombiano
}

\section{Productive strengthening of the breeders of Cuy (Cavias porcellus) of the Colombian humid tropics}

\author{
Luis Carlos Ramírez Villa1', Pedro Gómez Bilbao², Jazmín Murcia³ \\ ${ }^{1}$ Docente de Unillanos, Grupo Agroforestería, LPA cMSc, \\ ${ }^{2}$ Docente Unillanos, Economista, MSc, PhD Grupo CEGER. \\ ${ }^{3}$ Estudiante de MVZ, Grupo de Estudio ECODER. \\ Jazmin.murcia@unillanos.edu.co \\ Icramirez@unillanos.edu.co
}

\section{RESUMEN}

INTRODUCCIÓN. La producción de Cuyes (Cavias porcellus) ha aumentado en la región de la Orinoquia, ello se debe en gran parte a que desde el 2013 se constituyó la unidad de producción de Cuyes de la Universidad de los Llanos, ya existen 10 núcleos en diferentes comunidades en las que se ha impulsado el aprovechamiento de esta especie para generar una proteína de origen animal económica y fácil de manejar, en el proceso se puede utilizar recursos locales en cuanto a su establecimiento y nutrición, a partir de forrajes propios de la región, lo que enriquece su valor para la seguridad alimentaria en comunidades rurales en condición de vulnerabilidad. OBJETIVO. Fortalecer la organización de los productores de cuyes (cavias Porcellus) como estrategia para garantizar la seguridad alimentaria en las poblaciones rurales de la Orinoquia Colombia. MATERIALES Y MÉTODOS. Este estudio se llevó a cabo en el piedemonte llanero. se realizó una encuesta a los propietarios de unidades productivas que implicaron visitas a las diferentes fincas para obtener información de los sistemas encontrados por medio de cuestionarios que se elaboraron para ser tabulados en una estadística descriptiva, una vez obtenida esta información se realizó un plan de capacitación con 10 familias seleccionadas. Las fuentes de información 
primaria a las que se recurrió son las unidades de análisis es decir las familias de las fincas cuya actividad principal sea la agropecuaria. RESULTADOS. El $82,60 \%$ de la población cuentan con SISBEN y el restante, es decir, $17,39 \%$ no cuentan con SISBEN. Referente al sistema de salud de la población rural sometida a estudio el $84,34 \%$ cuentan con un régimen de salud subsidiado, un $10,34 \%$ cuentan con un régimen de salud contributivo y tan solo un 5,21\% cuenta con un sistema de salud especializado. En cuanto al consumo de carne un $40 \%$ de la población rural estaría en un riesgo de seguridad alimentaria, mientras un $20 \%$ ya se encuentra en peligro de desnutrición, mientras que solo un $40 \%$ no presentaría riesgo. Los productores estos manifestaban el interés para la producción de Cavia porcellus debido a que esta especie requiere de poco espacio, fácil manejo a su vez de que en sus fincas cuentan con gran variedad de especies forrajeras aptas para la alimentación de los cuyes, la finalidad de un gran porcentaje de estos productores es para consumo propio y comercialización de la especie. La participación activa en la capacitación por parte de los productores genera las condiciones adecuadas en la región sobre el de conocimiento del manejo de la especie para que se implemente la producción de Cavias porcellus de forma comercial. CONCLUSIONES: La producción de cuy (Cavias porcellus) es una alternativa para la seguridad alimentaria, proporcionaría una solución rápida y de fácil manejo para la población rural que le proveería proteína de origen animal, lo que enriquecerá su dieta.

Palabras Clave: Cavias Porcellus, Productividad, organización comunitaria, Extensión, Desarrollo Rural

\section{ABSTRACT}

INTRODUCTION. The production of Cuyes (Cavias porcellus) has increased in the Orinoquia region, this is largely due to the fact that since 2013 the Cuyes production unit of the University of the Plains was established, there are already 10 nuclei in different communities in which the use of this species has been promoted to generate an animal protein of economic origin and easy to handle, in the 
process local resources can be used in terms of its establishment and nutrition, from forages of the region, which enriches its value for food security in vulnerable rural communities. OBJECTIVE. Strengthen the organization of guinea pig producers (Porcellus cavias) as a strategy to guarantee food security in the rural populations of the Orinoquia Colombia. MATERIALS AND METHODS. This study was carried out in the Piedmont. A survey was carried out on the owners of productive units that involved visits to the different farms to obtain information on the systems found through questionnaires that were prepared to be tabulated in a descriptive statistic, once this information was obtained, a training plan was carried out. with 10 selected families. The primary sources of information that were used are the units of analysis, that is, the families of the farms whose main activity is agriculture. RESULTS. $82.60 \%$ of the population have SISBEN and the rest, that is, $17.39 \%$ do not have SISBEN. Regarding the health system of the rural population under study, $84.34 \%$ have a subsidized health system, $10.34 \%$ have a contributory health system and only $5.21 \%$ have a health system. Specialized health Regarding meat consumption, $40 \%$ of the rural population would be at risk of food security, while $20 \%$ are already in danger of malnutrition, while only $40 \%$ would not present a risk. The producers expressed their interest in the production of Cavia porcellus because this species requires little space, easy handling, in turn, in their farms they have a wide variety of forage species suitable for feeding the guinea pigs, the purpose of $A$ large percentage of these producers is for own consumption and commercialization of the species. The active participation in the training by the producers generates the appropriate conditions in the region regarding the knowledge of the management of the species so that the production of Cavias porcellus is implemented commercially. CONCLUSIONS. The production of guinea pig (Cavias porcellus) is an alternative for food security, it would provide a quick and easy-to-use solution for the rural population that would provide protein of animal origin, which will enrich their diet.

Keywords: Cavias Porcellus, Productivity, community organization, Extension, Rural Development. 